\title{
TECTONOPHYSICAL APPROACH TO THE ANALYSIS OF GEOLOGICAL AND GEOPHYSICAL DATA ON GAS-CONDENSATE DEPOSITS WITH THE COMPLEX PLATFORM COVER
}

\author{
K. Zh. Seminsky, 2, V. A. Sankov1, 3, V. V. Ogibenin', Yu. P. Burzunova ${ }^{1}$, \\ A. I. Miroshnichenko', E. A. Gorbunova1, I. V. Gorlov', A. S. Smirnov ${ }^{4}$, \\ A. G. Vakhromeev ${ }^{1}$, I. V. Buddo', 2 \\ ${ }^{1}$ Institute of the Earth's Crust, Siberian Branch of RAS, Irkutsk, Russia \\ 2 Irkutsk Scientific Center, Siberian Branch of RAS, Irkutsk, Russia \\ ${ }^{3}$ Irkutsk State University, Irkutsk, Russia \\ ${ }^{4}$ LLC Gazprom Geologorazvedka, Tyumen, Russia \\ 5 Tyumen Industrial University, Tyumen, Russia
}

\begin{abstract}
The article presents the results of the tectonophysical approach to the analysis of stress fields and the structure of gas-condensate deposits with the complex platform cover. The discussed case is the Kovykta license area (LA) in Eastern Siberia, Russia. In the upper part of the cross section, the network of fault zones was identified from the relief lineaments and structural data. The dynamic conditions for faulting (compression, extension, and strike-slip) were reconstructed by the paragenetic analysis. The state of crustal stresses in the study area was studied by tectonophysical modeling using gelatin as an optically active material. The applied method was successful in distinguishing between the zones of faults in the platform cover, which differ in the degree of their activity in the specified stress fields. The lower part of the cross section in the NE segment of the Kovykta LA is considered as an example of the tectonophysical interpretation of the electrical and seismic survey data in order to identify the fault zones and reconstruct the corresponding stress fields. Based on the synthesis of the analyzed data, it is revealed that the deposits like the Kovykta gas condensate field (GCF) show the zone-block structure of the platform cover formed under the influence of several stress fields closely associated with the stages of tectogenesis in the adjacent mobile belts. The next objective is to enhance the tectonophysical approach in order to develop a hierarchical model of the GCF zone-block structure, which details need to be known for improving the prediction of sites with the complicated stress-strain state of rocks and mitigating the risks associated with drilling exploration and production wells.
\end{abstract}

Key words: fault zone; block; stress field; sedimentary cover; seismic survey; electromagnetic survey; physical modeling

\section{RESEARCH ARTICLE}

Received: June 26, 2018

Handling Editor: K.G. Levi

Revised: July 18, 2018

Accepted: July 23, 2018

For citation: Seminsky K.Zh., Sankov V.A., Ogibenin V.V., Burzunova Yu.P., Miroshnichenko A.I., Gorbunova E.A., Gorlov I.V., Smirnov A.S., Vakhromeev A.G., Buddo I.V., 2018. Tectonophysical approach to the analysis of geological and geophysical data on gas-condensate deposits with the complex platform cover. Geodynamics \& Tectonophysics 9 (3), 587-627. doi:10.5800/GT-2018-9-3-0364.

Для цитирования: Семинский К.Ж., Саньков В.А., Огибенин В.В., Бурзунова Ю.П., Мирошниченко А.И., Горбунова Е.А., Горлов И.В., Смирнов А.С., Вахромеев А.Г., Буддо И.В. Тектонофизический подход к анализу геолого-геофизических данных на газоконденсатных месторождениях со сложным строением платформенного чехла // Геодинамика и тектонофизика. 2018. Т. 9. № 3. С. 587-627. doi:10.5800/GT-2018-9-3-0364. 


\title{
ТЕКТОНОФИЗИЧЕСКИЙ ПОДХОД К АНАЛИЗУ ГЕОЛОГО- ГЕОФИЗИЧЕСКИХ ДАННЫХ НА ГАЗОКОНДЕНСАТНЫХ МЕСТОРОЖДЕНИЯХ СО СЛОЖНЫМ СТРОЕНИЕМ ПЛАТФОРМЕННОГО ЧЕХЛА
}

\author{
А. Г. Вахромеев ${ }^{1}$, И. В. Буддо ${ }^{1,2}$ \\ ${ }^{1}$ Институт земной коры СО РАН, Иркутск, Россия \\ ${ }^{2}$ Иркутский научный центр СО РАН, Иркутск, Россия \\ ${ }^{3}$ Иркутский государственный университет, Иркутск, Россия \\ ${ }^{4}$ ОоО «Газпром геологоразведка», Тюмень, Россия \\ 5 Тюменский индустриальный университет, Тюмень, Россия
}

К. Ж. Семинский ${ }^{1,2}$, В. А. Саньков ${ }^{1,3}$, В. В. Огибенин 4 , Ю. П. Бурзунова 1 , А. И. Мирошниченко ${ }^{1}$, Е. А. Горбунова ${ }^{1}$, И. В. Горлов ${ }^{4}$, А. С. Смирнов ${ }^{4}, 5$,

\begin{abstract}
Аннотация: В статье на примере Ковыктинского лицензионного участка (Восточная Сибирь) представлены результаты применения тектонофизического подхода к анализу полей напряжений и структуры газоконденсатных месторождений со сложным строением платформенного чехла. Для верхней части разреза на основе изучения линеаментов рельефа и геолого-структурных данных выделена сеть разломных зон и посредством реализации парагенетического анализа установлены динамические обстановки ее формирования (сжатие, растяжение, сдвиг). Проведено тектонофизическое моделирование на оптически-активном материале (желатин) напряженного состояния изучаемого участка земной коры и показана эффективность метода для разделения разломных зон платформенного чехла по степени их активности в определенном поле напряжений. На примере нижней части разреза в северо-восточной части Ковыктинского лицензионного участка осуществлена тектонофизическая интерпретация данных электро- и сейсморазведки с выделением разломных зон и реконструкцией полей напряжений, в которых происходило их развитие. В итоге синтеза разнородных результатов показано, что для месторождений, подобных Ковыктинскому газоконденсатному месторождению (ГКМ), характерно зонно-блоковое строение платформенного чехла, сформированное под влиянием нескольких полей напряжений, тесно связанных с этапами тектогенеза в смежных подвижных поясах. Задачей дальнейших исследований по проблеме является углубление тектонофизического подхода для разработки иерархической модели зонно-блокового строения ГКМ, детальность которой позволит осуществлять эффективный прогноз участков со сложным напряженно-деформированным состоянием пород, неблагоприятным для проходки разведочных и эксплуатационных скважин.
\end{abstract}

Ключевые слова: разломная зона; блок; поле напряжений; осадочный чехол; сейсморазведка; электроразведка; физическое моделирование

\section{1. ВВЕДЕНИЕ}

В тектонофизике анализ строения и напряженного состояния деформационных структурных элементов земной коры производится на основе представлений о механизме их формирования. Так, в отношении разломов принципиальным является учет полной истории развития их внутренней структуры, начиная от заложения широкой зоны повышенной плотности сравнительно мелких опережающих разрывов и заканчивая образованием и этапами активизации магистрального сместителя, нарушающего полностью деформируемый объем земной коры. Термин «разломная зона» после известной монографии Семена Иойновича Шермана с соавторами [Sherman et al., 1983] трактуется широко, так как включает не только тектониты разломного сместителя, но и существенно большие по размерам объемы горных пород, в которых имели место генетически связанные с его формированием пластические и разрывные деформации.

Разломная зона, как трехмерное физическое тело, характеризуется внутренней структурой, под которой понимается совокупность деформационных элементов, определяющих специфику ее строения в отличие от окружающих пространств. В сравнении с традиционными представлениями тектоники полный парагенезис структурных элементов 2-го порядка, развивающихся в зоне разлома (сместителя 1-го порядка), существенно расши- 
(a)

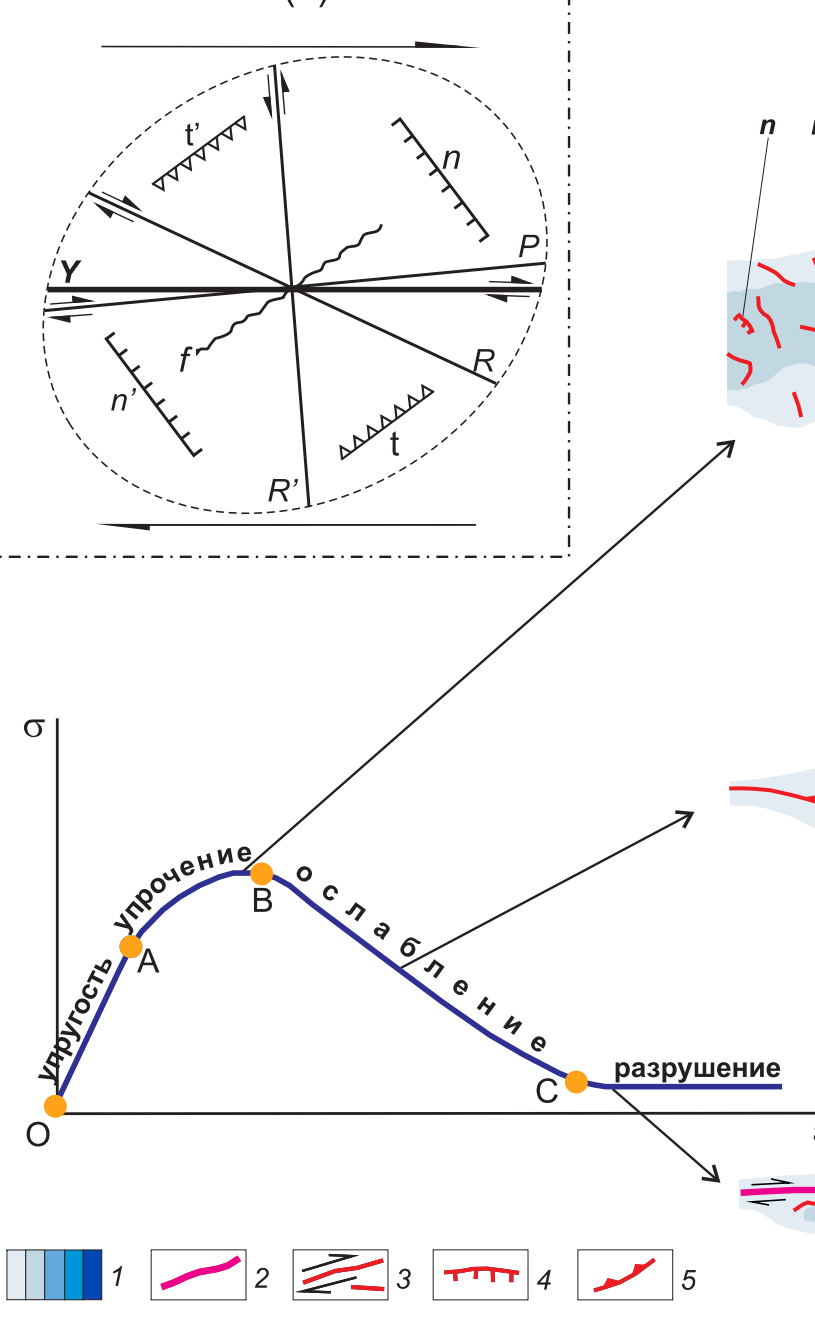

(б)

\section{ранняя дизъюнктивная стадия}

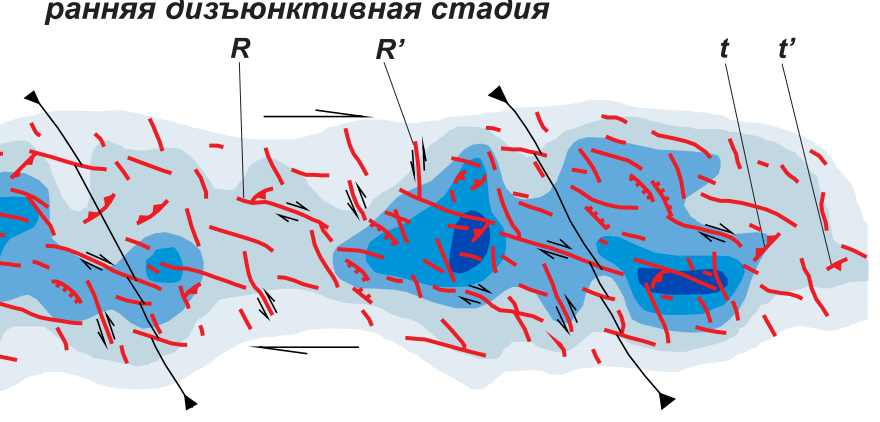

поздняя дизъюнктивная стадия

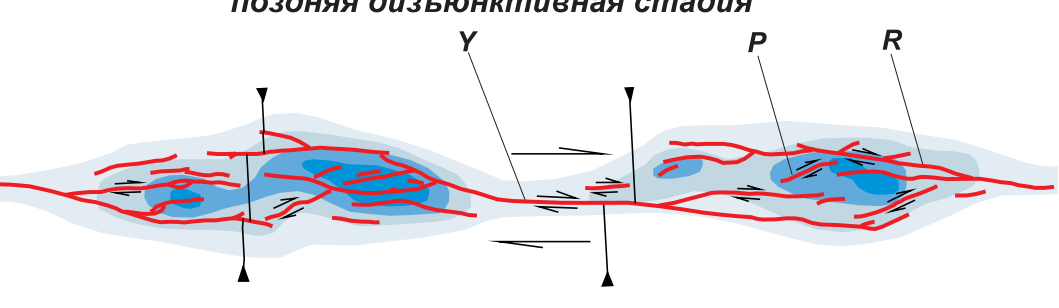

стадия полного разрушения

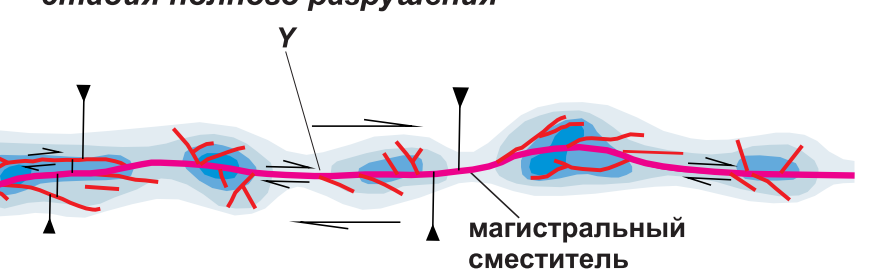

Рис. 1. Тектонофизические основы парагенетического анализа разломных зон (на примере правого сдвига). $(a)$ обобщенная диаграмма, иллюстрирующая системы эшелонированных структурных элементов, которые образуются в разломной зоне при простом скалывании (по [Tchalenko, 1970; Wilcox et al., 1973; Freund, 1974; Harding, 1974; Friedman et al., 1976; Sherman et al., 1983; Hancock, 1985; Naylor et al., 1986; Mandl, 1988; Sylvester, 1988; Park, 1997; Kim et al., 2004; и др.]): Y, R', R и P - сдвиги; n' и n - сбросы; t' и t - взбросы; f - оси складок. (б) - принципиальная схема формирования внутренней структуры разломной зоны. Главные стадии разрывообразования соответствуют трем характерным отрезкам на кривой «нагрузка $(\sigma)$ - деформация $(\varepsilon) »$.

1 - участки с различным количеством разрывов в единице площади; 2 - магистральный сместитель (разрыв 1-го порядка); 3-5 - сдвиги (3), сбросы (4) и надвиги (5) 2-го порядка.

Fig. 1. Tectonophysical basis for the paragenetic analysis of fault zones (case of a right-lateral strike-slip fault). (a) - generalized diagram illustrating the systems of echeloned structural elements formed in the fault zone due to simple shear (e.g. [Tchalenko, 1970; Wilcox et al., 1973; Freund, 1974; Harding, 1974; Friedman et al., 1976; Sherman et al., 1983; Hancock, 1985; Naylor et al., 1986; Mandl, 1988; Sylvester, 1988; Park, 1997; Kim et al., 2004]): Y, R ', R and P - strike-slip faults; n' and n normal faults; $\mathrm{t}^{\prime}$ and $\mathrm{t}$ - reverse faults; $\mathrm{f}$ - folding axes. (б) - principal diagram showing formation of the internal structure of the fault zone. The main stages of fracturing correspond to three characteristic segments on the load $(\sigma) / \operatorname{deformation}(\varepsilon)$ curve.

1 - sites that differ in the number of fractures per unit area; 2 - main fault plane (1 1 st-order fracture); $3-5-2^{\text {nd }}$ oder strike-slip (3) normal (4), and thrust (5) faults.

рился за счет разрывов и складок, формирующихся на ранней стадии разломообразования (рис. 1). Кроме известных систем сколов 1-й серии (R- и R'), в зоне могут развиваться эшелонированные склад- ки (f), а также разрывы 2-й (n, n') и 3-й (t, t') серии, морфогенетический тип которых кардинально отличается от типа разломной зоны (например, сбросы и взбросы в зоне сдвига). Описанные представ- 
ления составили основу современного тектонофизического подхода к изучению разломов, однако его истоками в существенной степени являлись результаты исследований прикладной направленности, которые проводились в 70-х годах прошлого века при картировании нефтегазоносных зон сгущения разрывов и складок [Wilcox et al., 1973; Harding, 1974; Harding, Lowell, 1979].

Новый этап активного применения представлений тектонофизики для решения прикладных проблем нефтегазопоисковой отрасли связан с применением наиболее общих закономерностей строения разломных зон, контролирующих проявления углеводородов, для интерпретации уникальных геофизических материалов и, в частности, детальной сейсморазведки. В ряде случаев на геофизических разрезах и картах отчетливо выделяются сгущения разрывов, а также смещения ими маркирующих горизонтов осадочного чехла [Wiprut, Zoback, 2000; Gogonenkov, Timurziev, 2010; Nezhdanov et al., 2012; Zeng et al., 2010]. Это позволяет, используя эталонные наборы разрывов 2-го порядка, установить тип продуктивной разломной зоны 1-го порядка и главные закономерности ее внутреннего строения. В более сложных структурных ситуациях применяется анализ комплекса атрибутов сейсмического волнового поля, позволяющий выделять множество разноранговых нарушений осадочной толщи, большинство из которых относится к мелким разрывам, не имеющим видимых смещений [Bahorich, Farmer, 1995; Glukhmanchuk, Vasilevskiy, 1998, 2013; Mushin et al., 2001; Canh et al., 2006; Chopra, Marfurt, 2005; Brutton et al., 2006; Chopra et al., 2009; Khromova, 2008; Nezhdanov et al., 2012; Mendry, Tyapkin, 2012; Aarre et al., 2012; Mendry, 2013; Skvortsov, Kuleshov, 2014; Glukhmanchuk et al., 2016]. Вместе с тем, согласно цитированным работам, именно их сети зачастую определяют типы углеводородных ловушек, осложняют строение продуктивных коллекторов, контролируют пространственное распределение участков аномальных давлений, а также образуют структурную основу большинства разломных зон, которые в платформенном чехле находятся на ранней стадии развития и не содержат сместителей магистрального типа (рис. 1, б).

Последние тектонофизические разработки, объединенные под общим названием «специальное структурное картирование» (спецкартирование), позволяют выделять в подобных, сложных для исследований, условиях разломные зоны, определять динамические особенности их формирования и ключевые особенности внутреннего строения [Seminsky, 2014, 2015; Seminsky K.Zh., Seminsky Zh.V., 2016]. Предметом для проведения анализа в рамках спецкартирования являются схемы разрывных структур, выделенных при обработке структурных, морфотектонических и разнотипных геофизических данных.

Целью данного исследования было апробировать на примере Ковыктинского газоконденсатного месторождения (ГКМ) современные приемы и способы тектонофизического анализа, направленные на выявление главных закономерностей строения платформенного чехла, обусловленных наличием разломных зон и особенностями их развития на разных этапах тектогенеза.

Выбор в качестве объекта тектонофизических исследований Ковыктинского ГКМ в пределах одноименного лицензионного участка (рис. 2, a) обусловлен, во-первых, его сложным строением и, вовторых, - гигантскими запасами углеводородного сырья, локализованными в природном резервуаре парфеновского горизонта чорской свиты венда [Smirnov et al., 2016]. Исследование направлено, с одной стороны, на выявление закономерностей строения разрабатываемого в настоящее время крупнейшего для Восточной Сибири месторождения газа, а с другой - на установление главных особенностей деформационного процесса, характерных для фронтальной зоны отраженной складчатости юга Сибирской платформы [Sizykh, 2001], где располагается ряд месторождений углеводородов (Ковыктинское, Атовское, Тутурское и др.).

Сложность исследования подобных месторождений определяется сочетанием ландшафтного, структурного и вещественного факторов. Первый из них заключается в слабой обнаженности горных пород платформенной территории для применения прямых геолого-структурных методов картирования разломов. Второй - структурный - фактор состоит в характерном для зоны отраженной складчатости относительно слабом проявлении тектонических деформаций, прежде всего разломного типа. При интерпретации геофизических данных их стиль и особенности установить сложнее, чем в случае присутствия разломов с существенными смещениями в более дислоцированных регионах или, наоборот, для участков, где платформенный чехол практически не деформирован. Третий - вещественный - фактор определяется наличием в осадочной толще соляных горизонтов, которые даже при небольших наклонах способны к течению под действием сил гравитации и бокового стресса.

Наложение сопоставимых по интенсивности тектонического и гравитационного процессов формирует сложную среду, в которой имеют место области аномально низких (АНПД) и аномально высоких давлений (АВПД) флюидных систем в природных трещинных резервуарах [Vakhromeev, Khokhlov, 1988; Vakhromeev et al., 2006, 2016; Il'in et al., 2016; Gorlov et al., 2016], получены рапопроявле- 
(a)

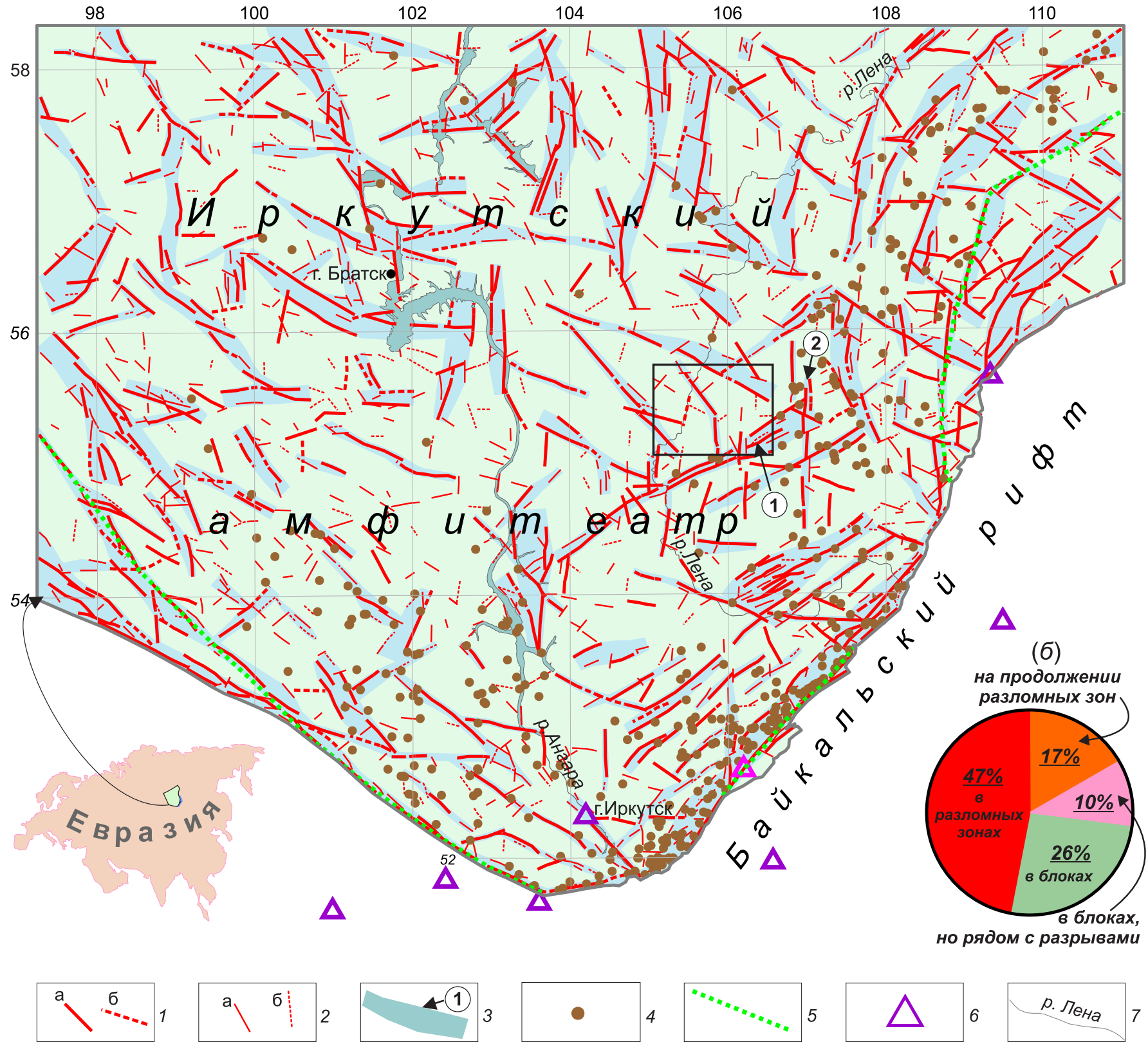

Рис. 2. Закономерности деструкции земной коры Иркутского амфитеатра, представленные на схеме активных в новейшее время разломных зон $(a)$ и диаграмме, отражающей приуроченность платформенных землетрясений к зонам или блокам (б). Прямоугольник - Ковыктинский лУ.

1 - крупные разрывы, отчетливо (а) и менее отчетливо (б) выраженные в рельефе; 2 - то же для мелких разрывов; 3 - разломные зоны, в т.ч. Жигаловская (1) и Хандинская (2); 4 - эпицентры землетрясений согласно каталогу Байкальского филиала ЕГС РАН; 5 - краевой шов платформы; 6 - сейсмостанции; 7 - гидросеть.

Fig. 2. Regular features of the crustal destruction in the Irkutsk amphitheater. The schematic map $(a)$ shows modern active fault zones $(a)$. The diagram (б) shows the platform earthquakes that occurred in the zones or blocks. The Kovykta license area (LA) is marked by a box.

1 - large faults that are clearly (a) and less clearly (б) manifested in the relief; 2 - the same for small fractures; 3 - fault zones, including the Zhigalovo (1) and Khanda (2); 4 - earthquake epicenters according to the catalog published by the Baikal Branch of the RAS Geophysical Survey; 5 - marginal suture of the platform; 6 - seismic stations; 7 - hydrographic network.

ния в процессе бурения, а распределение углеводородов характеризуется существенной неравномерностью. Типичный пример проявления процессов подобного типа на территории, слабодоступной для применения прямых методов картирования деформационных структур, - Ковыктинский ли- 
цензионный участок (ЛУ) [Vakhromeev, Khokhlov, 1988; Vakhromeev et al., 2016; Smirnov et al., 2016; Buddo et al., 2016]. Это послужило причиной выбора его в качестве объекта для апробирования тектонофизического подхода к анализу разнотипной геолого-геофизической информации.

Задачами исследования были:

1) выявить на основе тектонофизической интерпретации морфотектонических данных разломные зоны и динамические обстановки их формирования для верхней части осадочной толщи на Ковыктинском ЛУ;

2) установить на базе тектонофизической интерпретации материалов электро- и сейсморазведки характер разломной структуры и типы полей напряжений для нижней части платформенного чехла в пределах наиболее изученной северовосточной площади Ковыктинского ЛУ для последующего прогноза горно-геологических условий бурения;

3) сопоставить результаты тектонофизических исследований разных частей осадочной толщи и на этой основе установить характер и этапность формирования разломной структуры Ковыктинского лу.

\section{2. ОБЪЕКТ И МЕТОДЫ ИССЛЕДОВАНИЯ}

Объект исследований - Ковыктинское ГКМ располагается на юге Сибирской платформы в пределах одноименного тектонического блока, находящегося в восточной части Ангаро-Ленской тектонической ступени. На востоке и юго-востоке блок ограничен соответственно Хандинским и Жигаловским разломами (рис. $2, a$ ). В неотектоническом отношении ГКМ расположено в пределах АнгароЛенского поднятия, которое на востоке сочленяется с Предбайкальским кайнозойским прогибом. Границами области максимального возвышения вершинной поверхности в северной части АнгароЛенского поднятия служат Хандинская и Чиканская впадины, заложенные вдоль Хандинского и Жигаловского валов, сформировавшихся в палеозое. Морфолого-генетические типы разломов чехла Иркутского амфитеатра Сибирской платформы для раннего этапа развития охарактеризованы по результатам геологической съемки [Tsobin, Adamov, 1978; Mogilev, 1978] и в специализированных работах по тектонике [Dubrovin, 1979; Malykh, 1985; Ryazanov, 1973; Sizykh, 2001]. Разломы кайнозойского этапа активизации этой части Сибирской платформы отражены на различных картах и схемах неотектоники [Zolotarev, 1967; Zolotarev, Khrenov, 1979; Zamaraev et al., 1976; Levi, Kulchitsky, 1981; Logachev, 1984; и дp.]. Их кинема- тика для исследуемой территории охарактеризована в работах [Ufimtsev et al., 2005; Sankov et al., 2008, 2017].

Осадочный чехол, вмещающий газоконденсатное месторождение, по данным МОГТ может достигать мощности в несколько тысяч метров и по структурно-литологическим особенностям делится на три формационных комплекса: подсолевой, соленосный и надсолевой (рис. 3 , б). На выветрелой поверхности метаморфизованных пород фундамента с размывом и угловым несогласием залегают отложения подсолевого комплекса (рифей - венд нижний кембрий), в составе которого выделяется парфеновский горизонт с основными локализованными запасами природного газа. Породы солевого комплекса по мощности могут достигать 1800 м и представлены переслаиванием главным образом каменной соли с доломитами, известняками и ангидритами. Надсолевой комплекс сложен терригенно-карбонатными отложениями среднего верхнего кембрия и терригенными породами ордовика, которые на отдельных участках перекрываются четвертичным аллювием.

Гигантское Ковыктинское ГКМ располагается в пределах трех лицензионных участков, один из которых - Ковыктинский - является объектом исследований, представленных в данной статье (см. рис. 2, a). По материалам электроразведки [Buddo et al., 2012, 2013; Misyurkeeva et al., 2016] в разрезе осадочного чехла выделяется до восьми геоэлектрических горизонтов, отличающихся по электропроводности в связи с различием состава и коллекторских свойств. По результатам сейсморазведочных и электроразведочных работ в разрезе фиксируются разрывные нарушения северо-восточного и субмеридионального направлений, что соответствует простиранию упомянутых выше крупных дизъюнктивных структур (Жигаловский и Хандинский разломы), которые были закартированы ранее по данным геолого-съемочных исследований. Как показали результаты линеаментного анализа релье$\phi$ (см. рис. 2 [Seminsky et al., 2008]), на неотектоническом этапе развития Иркутского амфитеатра даже эти протяженные дизъюнктивы представляют широкие зоны субпараллельных разрывов, располагающихся вдоль бортов одноименных впадин. В верхней части осадочного чехла они не образуют единых магистральных сместителей, что, согласно рис. $2, a$, характерно и для других дизъюнктивов в связи со слабой тектонической активностью рассматриваемого региона.

Методы исследования дизъюнктивных структур подобного типа, использованные на Ковыктинском ЛУ для решения поставленных задач, базируются на тектонофизических закономерностях тектонической делимости земной коры. Согласно 


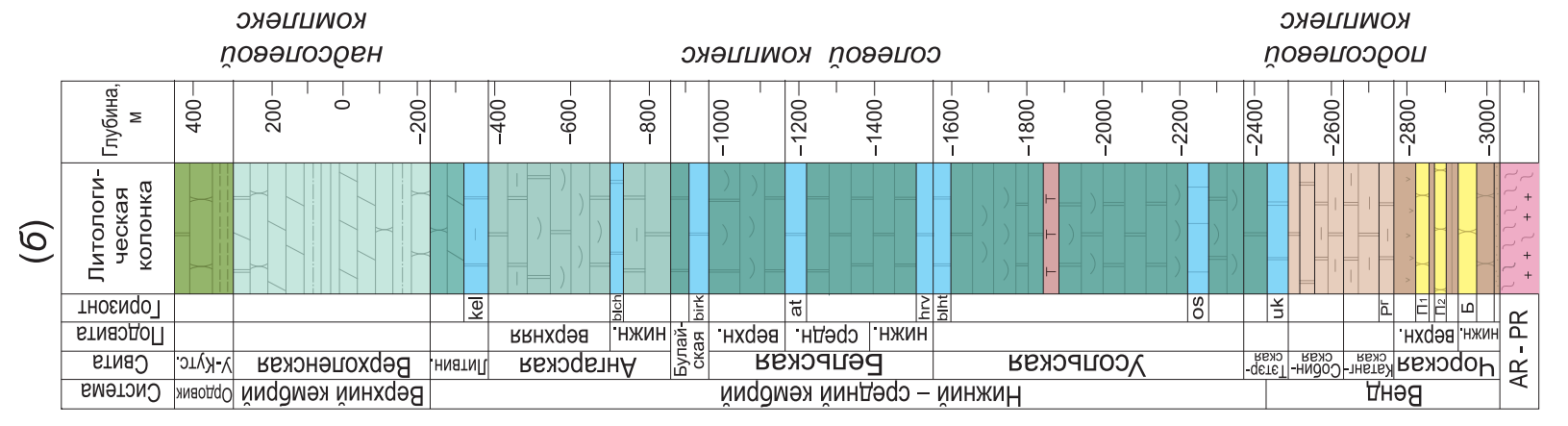



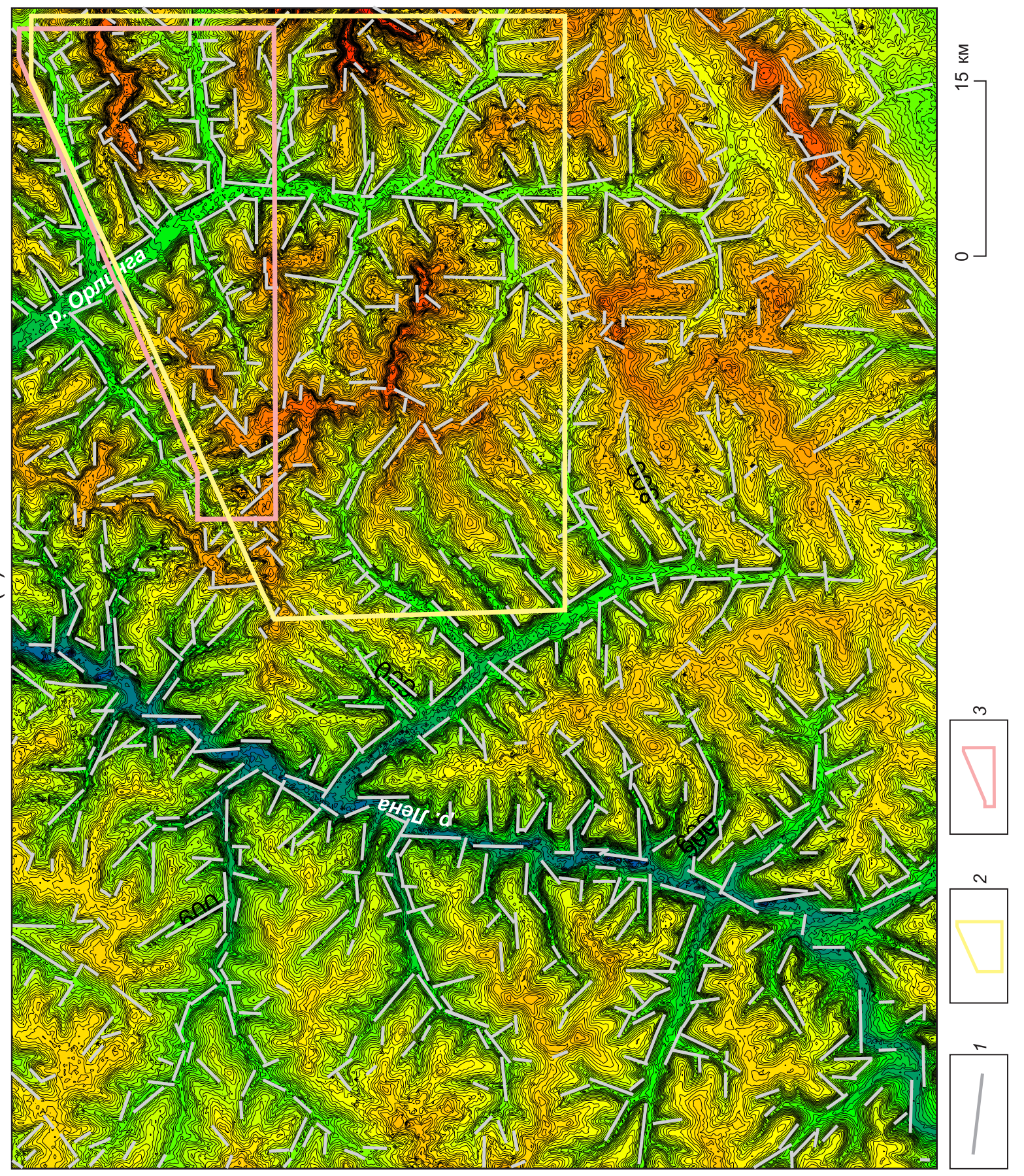

产 
работам [Sadovsky et al., 1987; Seminskii, 2008], она является зонно-блоковой, т.е. представляет иерархию блоков, контактирующих друг с другом в плане и в разрезе по широким зонам повышенной нарушенности породного массива. В период тектонической активизации это зоны разломного типа, внутренняя структура которых находится на одной из трех стадий развития [Seminsky, 1990, 2003] в зависимости от интенсивности и длительности силового воздействия на участок коры (см. рис. 1, б).

Разлом на дизъюнктивной стадии полного разрушения представлен единым магистральным сместителем и крупными оперяющими нарушениями, причем разрушение деформируемого объема является полным лишь с точки зрения механики, так как два обособленных блока контактируют друг с другом по зоне тектонитов (см. рис. 1 , б). На поздней дизъюнктивной стадии разлом выражен существенно меньшей по размерам зоной распространения активных опережающих разрывов, представленных небольшими фрагментами магистрального сместителя, между которыми располагаются интенсивно нарушенные широкие области их взаимодействия. На ранней дизъюнктивной стадии имеет место широкая зона сравнительно мелких опережающих разрывов, которую в геологической практике обычно называют зоной повышенной трещиноватости, зоной скрытого разлома и пр. Именно последняя структурная форма наиболее характерна для разломных зон платформенного чехла, поскольку сравнительно слабая тектоническая активность подобных регионов, как правило, не позволяет достичь третьей стадии развития внутренней структуры, т.е. формирования магистрального сместителя, который обычно имеет место в фундаменте.

Соответствие набора систем разрывов 2-го порядка, формирующихся в разломной зоне, ее морфогенетическому типу и, соответственно, полю напряжений 1-го порядка (см. рис. 1) позволяет использовать парагенетический анализ в качестве главной составляющей тектонофизического подхода к обработке разнотипных геолого-геофизических материалов с целью реконструкции динамических обстановок формирования дизъюнктивной структуры платформенных регионов. Для восстановления полей палеонапряжений на Ковыктинском ЛУ использовалась новая модификация парагенетического анализа, которая в полном объеме представлена в рамках метода спецкартирования разломных зон земной коры [Seminsky, 2014, 2015; Seminsky K.Zh., Seminsky Zh.V., 2016]. Метод позволяет путем сравнения природного и эталонных парагенезисов разрывов 2-го порядка определить напряженное состояние, которое послужило причиной формирования разломной зоны 1-го по- рядка, а также ее морфогенетический тип и элементы внутреннего строения.

Эталонные структурные парагенезисы (эталоны), представляющие модели разломно-трещинных сетей в зонах скалывания разломного типа (рис. 4), составлены в результате обобщения теоретических, экспериментальных и природных закономерностей разрывообразования для трех основных типов динамических обстановок - сжатия, сдвига и растяжения [Seminsky, 2003]. Эталон включает главный разломный сместитель 1-го порядка, семь систем опережающих мелких разломов 2-го порядка (R-, t-, n-, Т-типов), а также соответствующие каждой из них (и, в свою очередь, являющиеся для них опережающими структурами 2-го порядка) парагенезисы еще более мелких разрывов в виде троек систем трещин.

Каждый эталон в виде трафарета (рис. 4) представляет полный набор разрывных систем для всех основных типов разломных зон - правого и левого сдвига, сброса и взброса (надвига) с разными углами падения сместителей. Разломные парагенезисы, приведенные в виде трафарета зоны скалывания в плане с указанием простираний систем вторичных разрывов (рис. 4, 2), предназначены для использования в том случае, когда углы и направления падения тектонических нарушений не известны и предметом для парагенетического анализа является роза-диаграмма их простираний. При наличии полной информации о положении разрывов (азимут и угол падения) применяются эталоны разломно-трещинных (рис. $4, a$ ) и разломных (рис. 4, б) парагенезисов, которые составлены в виде круговых трафаретов в равноугольной проекции верхней полусферы. На них значками показаны полюсы плоскостей магистрального сместителя, вторичных разломов и троек систем трещин, взаимное положение которых сопоставляется с максимумами полюсов разрывов, выделяющимися на круговой диаграмме (стереограмме), построенной для природной разрывной сети в соответствии с известными из структурной геологии правилами.

В процессе сравнительного анализа эталон, наиболее подходящий для круговой или розадиаграммы по совокупности совпадающих систем разрывов, определяет итоговое решение: ориентировку и морфогенетический тип структур 2-го порядка и разломной зоны в целом, а также поле напряжений, в котором она сформировалась. Для одной диаграммы может быть получено одно, два, три и, реже, более решений, свидетельствующих о разнотипных подвижках и, следовательно, о существовании нескольких этапов в развитии изучаемого массива.

Предметом парагенетического анализа являлись разрывные нарушения, выделенные на 

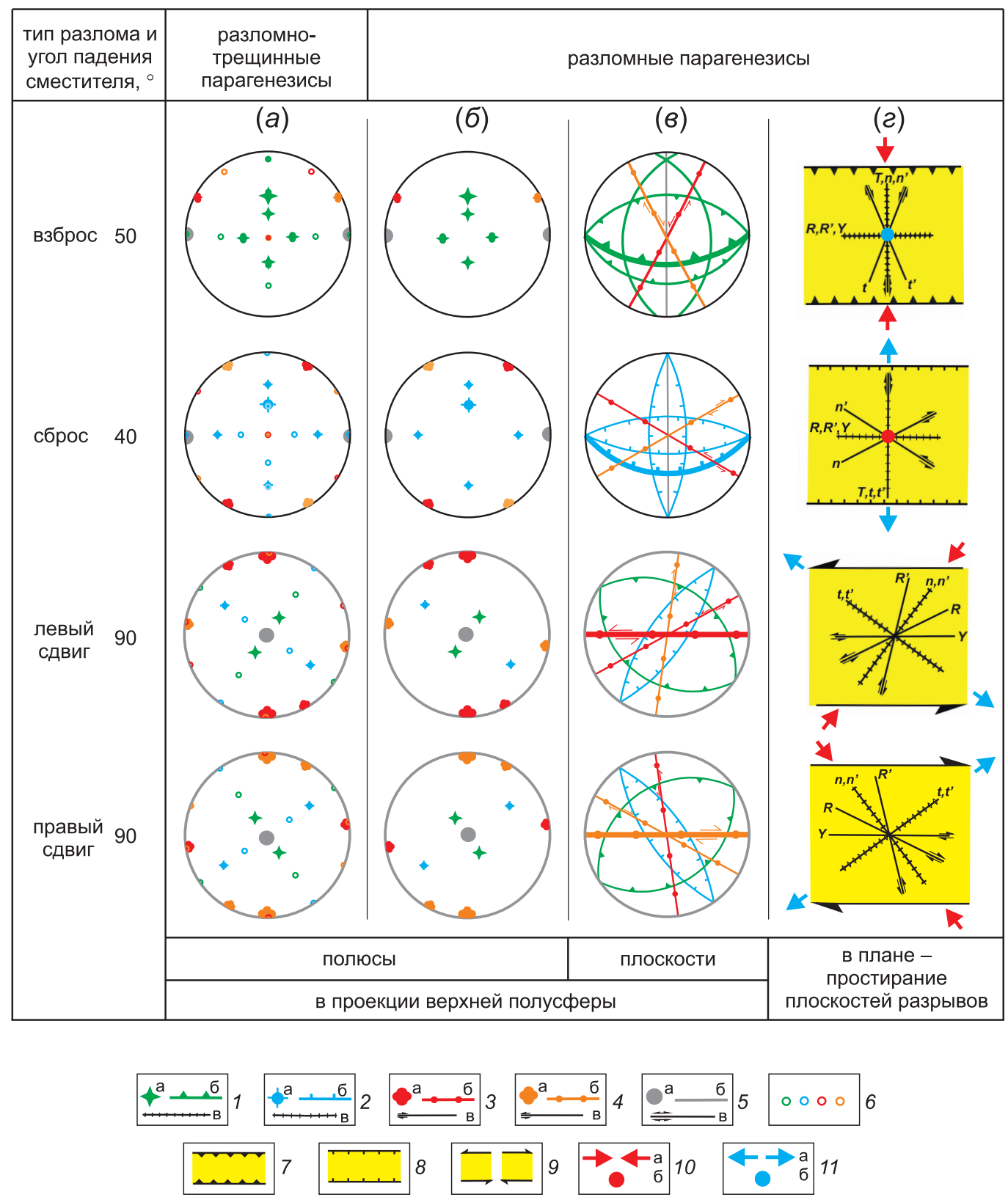

Рис. 4. Эталонные парагенезисы разрывов, имеющих место в зонах взброса (50), сброса (40), левого и правого сдвига. Парагенезисы представлены на круговых диаграммах (верхняя полусфера, сетка Вульфа) в полюсах (a-б) и плоскостях (в), а также простираниями плоскостей в плане (2). Полюсы вертикальных разрывных систем показаны половинками значков на противоположных сторонах круга. Латинскими буквами обозначены системы, однотипные в механическом отношении (2).

1-5 - полюсы (a), плоскости (б) и простирания плоскостей (в) сместителей 1-го (значок крупнее) и 2-го (значок мельче) порядка, являющихся взбросами (1), сбросами (2), левыми (3) и правыми (4) сдвигами, а также трансформационными разрывами (5); 6 - положение полюса второстепенной или дополнительной системы тройственного парагенезиса трещин (цвет знака соответствует цвету главной системы тройственного парагенезиса); 7-9 - зоны взброса (7), сброса (8), левого и правого сдвига (9); 10-11 - оси напряжений сжатия (10) и растяжения (11), занимающих субгоризонтальное (а) или субвертикальное (б) положение.

Fig. 4. Reference parageneses of fractures in the zones of reverse $\left(50^{\circ}\right)$, normal $\left(40^{\circ}\right)$, left- and right-lateral strike-slip faults. Parageneses are shown in circle diagrams (upper hemisphere, Wulff net) for poles (a-б), planes ( 8 ), and strike in plan ( 2 ). The poles of vertical fracture systems are shown by the halves of the symbols on the opposite sides of the circle. Latin letters - systems of the same type in terms of mechanics (2).

1-5 - poles (a), planes (б), and strike $(\theta)$ of the $1^{\text {st }}$ and $2^{\text {nd }}$ order (large and small symbols, respectively) fault planes: reverse faults (1), normal (2), left- (3) and right-lateral (4) strike-slip faults, and transform faults (5); 6 - positions of the poles of the secondary or additional systems of the triple paragenesis of fractures (the colour of the sign corresponds to the colour of the main system in the triple paragenesis); 7-9 - zones of reverse (7), normal (8), left- and right-lateral strike-slip faults (9); 10-11 - axes of compression (10) and extension (11) in the subhorizontal (a) or subvertical (б) position. 


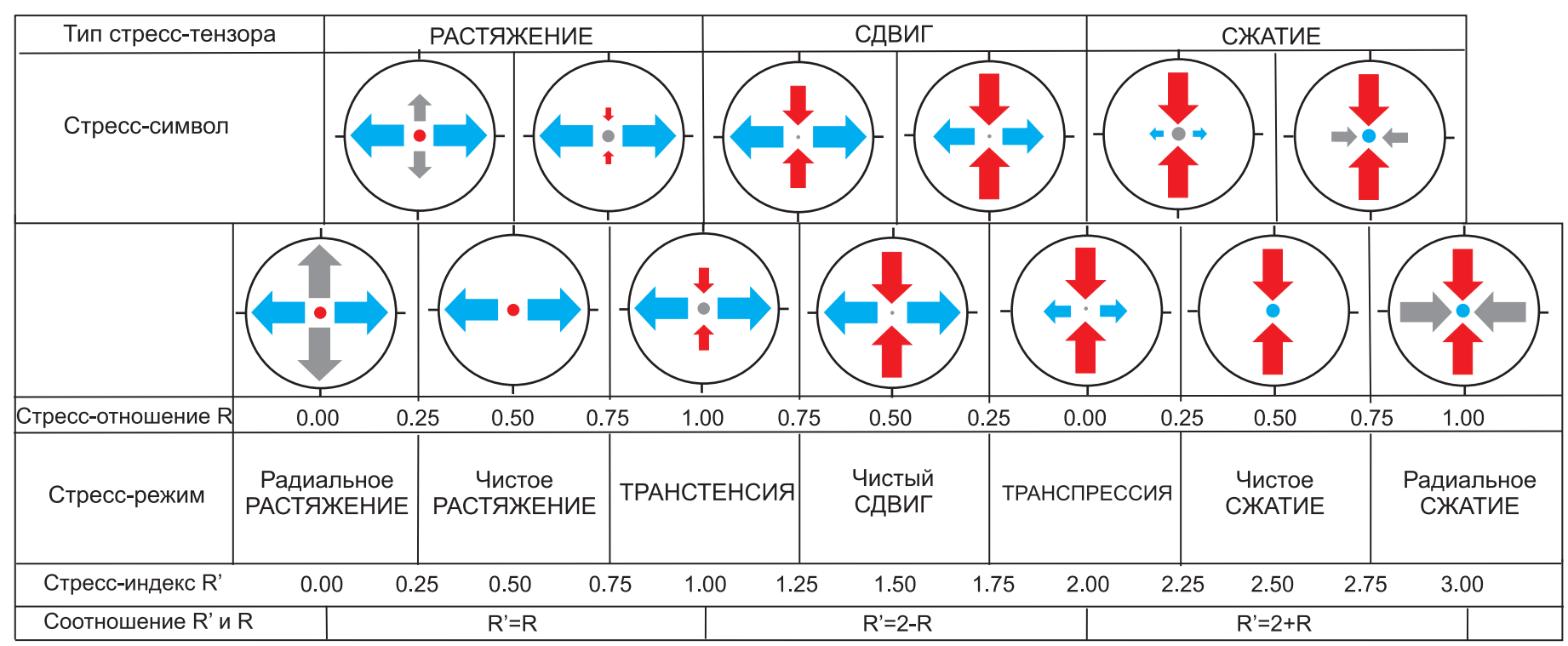

| Рис. 5. Классификация стресс-тензоров тектонических напряжений [Delvaux et al., 1997].

Fig. 5. Classification of tectonic stress tensors [Delvaux et al., 1997].

Ковыктинском ЛУ в ходе геолого-структурных, морфотектонических и геофизических исследований.

Геолого-структурные полевые исследования проводились на Ковыктинском ЛУ и за его южной и восточной границами с целью изучения полей напряжений, связанных с зонами Жигаловского и Хандинского разломов, отчетливо выраженных в рельефе. Для применения парагенетического анализа фиксировались элементы залегания трещин скола и отрыва, документировались зоны повышенной трещиноватости и дробления, устанавливались характер и амплитуды смещений различных маркирующих горизонтов или разновозрастных трещин. Особое внимание уделялось описанию зеркал скольжения, в частности ориентировке штрихов и борозд, направлению смещения и характеру вторичных изменений на плоскостях трещин, что позволило для восстановления полей тектонических напряжений использовать методику, опубликованную в статье [Delvaux, 1993]. Отнесение реконструированных стресс-тензоров к определенным режимам деформирования осуществлялось согласно рис. 5, составленному Д. Дельво [Delvaux et al., 1997] на базе классификации, опубликованной в работе [Guiraud et al., 1989]. В своей основе она соответствует систематике, разработанной С.И. Шерманом и Ю.И. Днепровским [Sherman, Dneprovsky, 1989] в ходе исследований поля напряжений Байкальского рифта.

Морфотектонические методы использовались в ходе полевых исследований для определения характера деформаций рельефа на Ковыктинском ЛУ и в окрестностях, а также при анализе его цифровых моделей, построенных с использованием космоснимков высокого разрешения «SRTM» и «ASTER GDEM2». Снимки первого типа применялись при построении карты рельефа вершинной поверхности и выделении областей локальных поднятий [Logachev, 1984], которые в районе Ковыктинского ЛУ могут быть причиной послойных срывов по солевым горизонтам вследствие дополнительной нагрузки, возникающей за счет увеличения высоты рельефа. Цифровые модели рельефа, построенные с использованием космоснимков второго типа, использовались для построения схемы рельефа Ковыктинского ЛУ в изолиниях (см. рис. $3, a$ ), которая являлась основой для выделения линеаментов. Происхождение этих спрямленных элементов рельефа (прямолинейных или слабоизогнутых уступов, отрезков речных долин и пр.) во многом связано с наличием в породном массиве тектонических нарушений. С учетом слабой обнаженности пород Ковыктинского ЛУ для проведения прямых геолого-структурных наблюдений морфотектонические исследования являлись основными для выделения разломных зон и реконструкции полей напряжений в верхней части осадочного чехла.

Геофизические методы стали основой для получения информации о дислокациях солевого и подсолевого комплексов. Для выделения разломных структур использовались данные 3-D сейсморазведки (материалы 000 «Газпром геологоразведка»), представляющие восточную часть Ковыктинского ЛУ (см. рис. 3, $a$ ). Во-первых, к ним относятся 
структурные карты отражающих горизонтов и сейсмические профили (рис. 6, a), визуальная обработка которых позволяет в некоторых случаях выделить разломы по смещению маркеров. Во-вторых, это сейсмический куб (рис. 6, б), для обработки которого применялась методика «Ant Tracking» [Pedersen et al., 2002; Aarre et al., 2012]. Она подчеркивает изменения волновой картины для обнаружения разрывов и других линейных аномалий внутри сейсмического куба. Используется концепция коллективного разума для помещения большого количества агентов в данные и последующей оценки коллективного поведения роя.

При обработке данных по Ковыктинскому ЛУ были рассчитаны три атрибута сейсмической записи: «неупорядоченность», «кривизна» и «дисперсия». Затем три куба были объединены в совокупный атрибут, полученный через нейронные сети. Данный атрибут анализировался при помощи «Ant Tracking», после чего выделенные разрывы отображались в виде полигонов. Это позволило для каждого из них определить азимут и угол падения, построить для куба в целом и отдельных локальных объемов в его пределах (ячеек) круговые структурные диаграммы, отражающие строение разрывной сети. Их сопоставление с круговыми эталонными трафаретами (см. рис. 4, $a$ ) обеспечило возможность получить для каждой из локальных ячеек частные решения и тем самым изучить пространственную структуру поля напряжений.

Электроразведка методом зондирований становлением поля в ближней зоне (ЗСБ) в модификации 3D ЗСБ проводилась для различных частей изучаемой территории, но детальные материалы были получены для практически треугольной площадки в северо-восточной части Ковыктинского ЛУ (см. рис. $3, a$ ). Основу исследований, рассматриваемых в статье, представляли карты продольной электрической проводимости, составленные специалистами АО «Иркутское электроразведочное предприятие» [Gorlov et al., 2016; Il'in et al., 2016] для отдельных горизонтов солевого и подсолевого комплекса (боханского, парфеновского, осинского, христофоровско-балыхинского, атовского, биркинского, бильчирского, келорского) (рис. 7, а). Необходимо отметить, что была проведена инверсия кривых ЗСБ в рамках тонкослоистых моделей, что позволило определить геоэлектрические характеристики непосредственно горизонтов-коллекторов [Pospeev et al., 2010; Buddo et al., 2011]. Главной задачей при анализе карт было установление генезиса зон повышенной электропроводности, и в случае их тектонического происхождения применение парагенетического анализа для выявления динамических обстановок деформирования нижней части осадочной толщи.
Геомеханические и сейсмологические материалы позволили привлечь к анализу информацию о типе поля напряжений, имеющем место в пределах Ковыктинского ЛУ на современном этапе тектогенеза. Первая группа данных включала определения стресс-тензоров по материалам исследования трещин, образующихся в процессе бурения скважин и зафиксированных в результате применения многорычажной кавернометрии и сейсмической локации очагов при гидроразрыве. На Ковыктинском ЛУ такие определения проводились для семи скважин, одна из которых находится в пределах северовосточного участка детальных исследований. В качестве сейсмологических материалов использовался каталог землетрясений БФ ЕГС РАН, обработка которого позволила проанализировать распределение эпицентров в краевой части платформы.

Как следует из краткой характеристики используемых в данном исследовании геолого-геофизических материалов, в наиболее полном объеме они представлены для треугольной площади, расположенной в северо-восточной части Ковыктинского ЛУ (см. рис. 3, a). В связи с этим он стал базовым полигоном для применения парагенетического анализа с целью выявления стиля и этапности процесса деструкции, проявившегося на разных глубинных уровнях платформенного чехла.

Лабораторное моделирование как важная составляющая тектонофизического подхода к изучению разломной структуры природных территорий применялось на Ковыктинском ЛУ для заверки результатов парагенетического анализа, а также выявления характера распределения интенсивности напряжений в разломах и блоках, выделенных по морфотектоническим данным. Физические эксперименты проводились по известной методике [Osokina, Tsvetkova, 1979], согласно которой модель из оптически-активного материала (желатин) с разрезами, имитирующими тектонические нарушения, подвергалась силовому нагружению на установке ППД-300 (рис. 8, a). Авторским добавлением к методике являлось применение процедуры «залечивания» разрезов менее вязким (по отношению к модельному) материалом, что позволяет получать более корректные результаты при моделировании сложнопостроенных разломно-блоковых структур земной коры. Результатом эксперимента являются цветовые картины, получаемые при исследовании нагруженной модели в проходящем поляризованном свете (рис. 8, б). На них представлено распределение коэффициента интенсивности касательных напряжений $\left(K_{\tau}\right)$, имеющее место в образце с разрывами при заданном силовом воздействии. Эти данные используются в качестве основы для определения типа и интенсивности подвижек по отдельным элементам разрывной сети, 
(a)
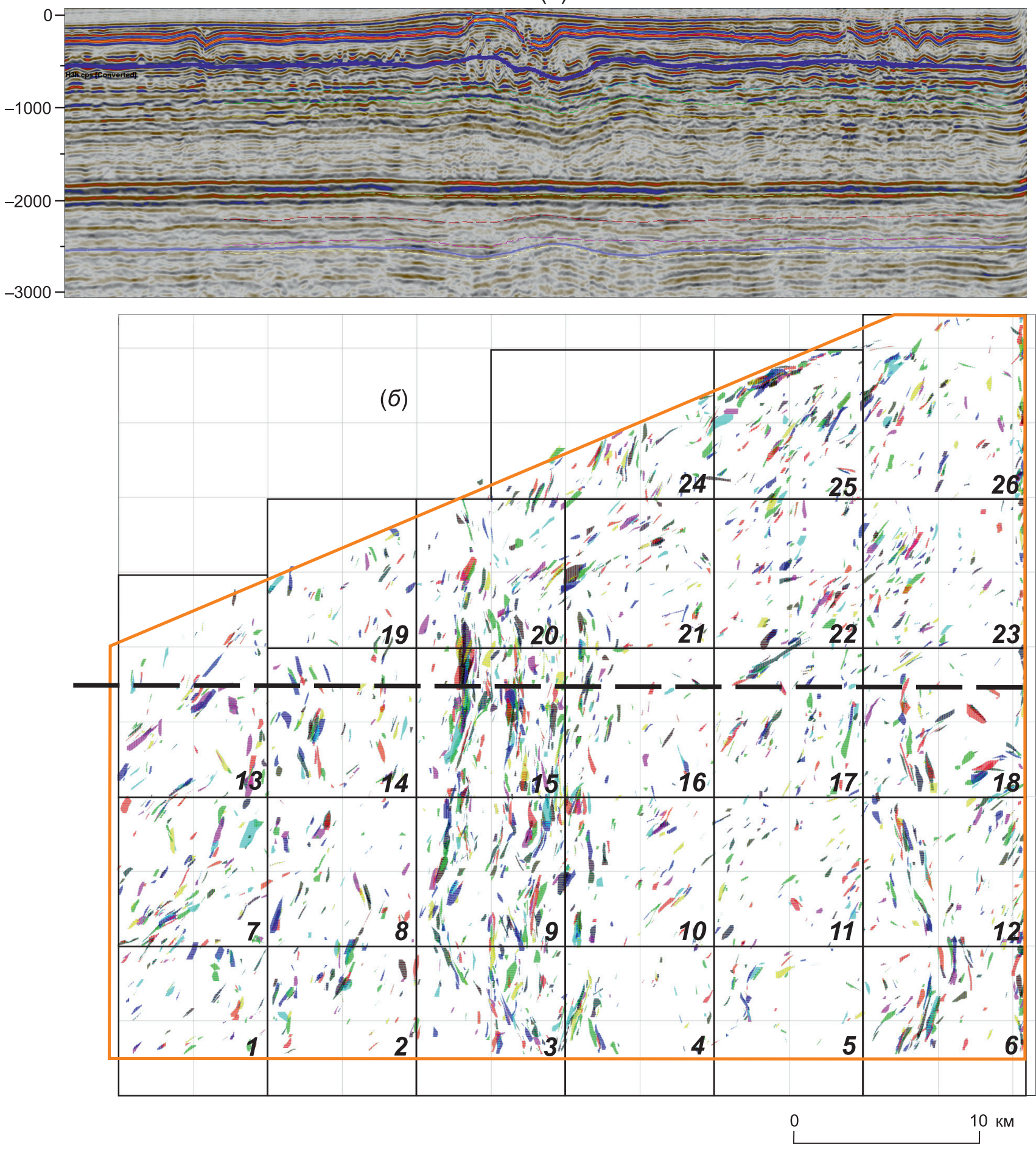

Рис. 6. Материалы детальной сейсморазведки, являвшиеся основой для проведения тектонофизического анализа на востоке Ковыктинского ЛУ (данные 000 «Газпром геологоразведка»). (a) - сейсморазведочный профиль, располагающийся вкрест простирания меридиональной зоны повышенной дислоцированности солевого комплекса; (б) - карта разрывов, выделенных из совокупного атрибута (объединяющего атрибуты «неупорядоченность», «кривизна» и «дисперсия») как проекции из сейсмического куба - слоя мощностью около 2.8 км, охватывающего в обозначенных границах солевой и подсолевой комплексы. Участок разделен на 26 ячеек, для каждой из которых сеть разрывов изучалась отдельно.

Fig. 6. Detailed seismic survey data used as the basis for the tectonophysical analysis of the eastern segment of the Kovykta LA (data of LLC Gazprom Geologorazvedka). (a) - seismic profile across the strike of the meridional zone of fracturing in the salt complex; (б) - map of faults identified from the cumulative attribute (combining the attributes of 'disorder', 'curvature' and 'dispursion'). Fault projections from the seismic cube (a $2.8 \mathrm{~km}$ thick layer including the salt and subsalt complexes within the specified boundaries). The site was divided into 26 cells, and the networks of fractures were studied separately in each cell. 


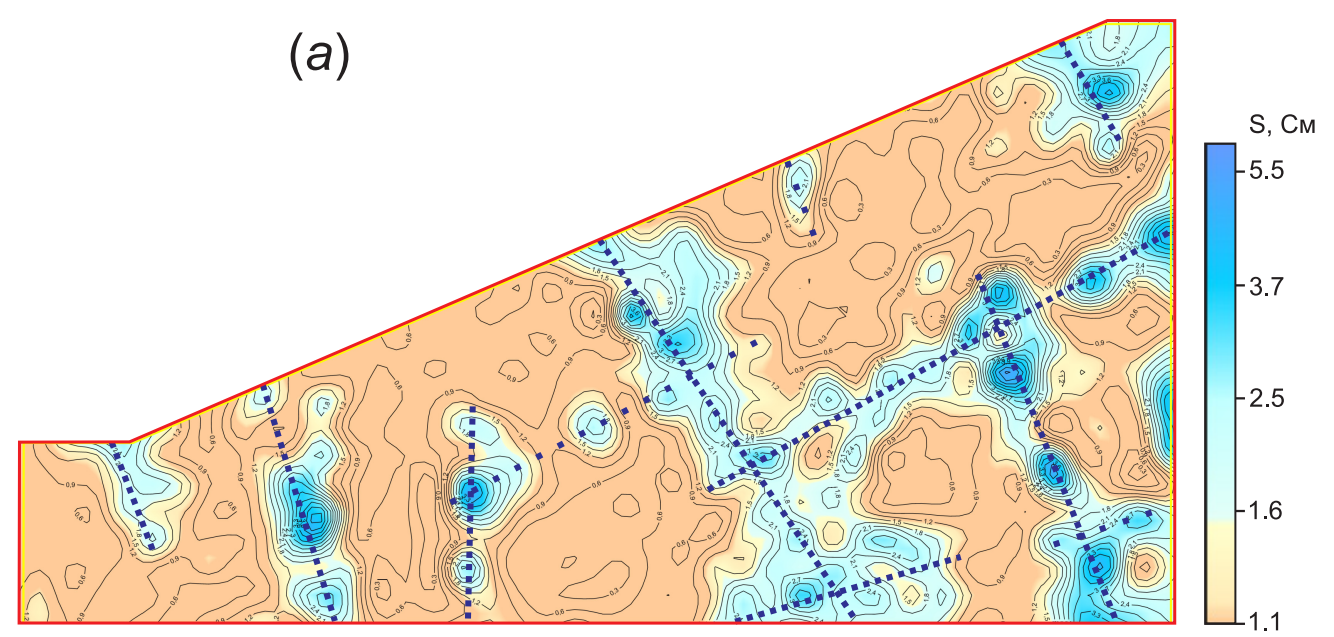

(в)
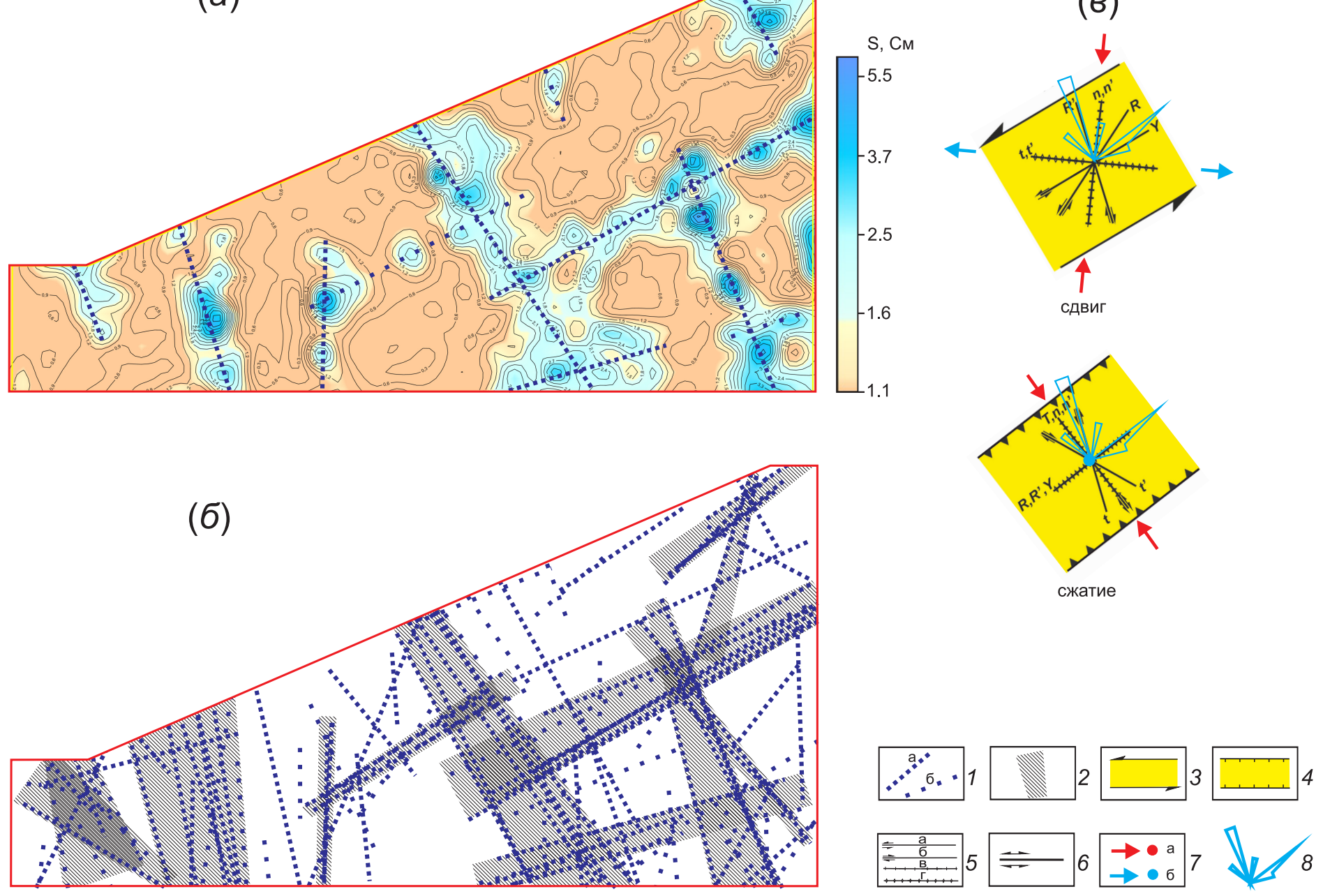

Рис. 7. Результаты тектонофизической интерпретации материалов детальных электроразведочных работ в северовосточной части Ковыктинского ЛУ. $(a)$ - карта продольной электропроводности (S) христофоровско-балыхинского горизонта, на которой оттенками синего цвета выделяются линейно вытянутые участки повышенных значений S, связанные с интенсивно нарушенными участками породного массива; (б) - схема разломных зон, представляющих сгущения субпараллельных осей зон повышенной электропроводности, выделенных на разных горизонтах в нижней части платформенного чехла; ( 8 ) - поля напряжений, реконструированные парагенетическим методом при изучении сети разломных зон, выделенных на участке детальных исследований при анализе карт электропроводности (латинские буквы - системы, однотипные в механическом отношении).

1 - оси зон повышенной электропроводности, выделенных с большей (а) и меньшей (б) степенью достоверности в пределах отдельных горизонтов солевого и подсолевого комплексов; 2 - разломные зоны; 3-4 - зоны левого сдвига (3) и взброса (надвига) (4) 1-го порядка; 5 - плоскости левых сдвигов (а), правых сдвигов (б), сбросов (в) и взбросов (надвигов) (г) 2-го порядка; 6 плоскости трансформационных сдвигов 2-го порядка (в зоне сдвига совпадают с плоскостью рисунка); 7 - оси сжатия (а) и растяжения (б), занимающие субгоризонтальное (стрелка) или субвертикальное (точка) положение в пространстве; 8 - розадиаграмма простираний осей электропроводящих разломных зон.

Fig. 7. Results of the tectonophysical interpretation of the detailed electrical survey data on the NE segment of the Kovykta LA. (a) - map of the longitudinal electrical conductivity (S) of the Khristoforov-Balykhin horizon; the shades of blue colour mark linearly elongated sites with higher $\mathrm{S}$ values associated with intensely fractured rocks; (б) - schematic map of fault zones represented by densely spaced subparallel axes of the zones of increased electrical conductivity; the fault zones are detected at different horizons in the lower part of the platform cover; $(\theta)$ - stress fields reconstructed by the paragenetic method applied to study the network of fault zones identified on the detailed survey site by the analysis of electrical conductivity maps. Latin letters - systems of the same type in terms of mechanics.

1 - axes of the zones of increased electrical conductivity, which were identified with the higher (a) and lower (б) levels of confidence within the individual horizons of the salt and subsalt complexes; 2 - fault zones; 3-4 - zones of the 1st order left-lateral strike-slip (3) and reverse (thrust) (4) faults; 5 - planes of the $2^{\text {nd }}$ order left-lateral strike-slip (a), right-lateral strike-slip (б), normal (в) and reverse (thrusts) (г) faults; 6 - planes of the $2^{\text {nd }}$ order transform strike-slip faults (in the strike-slip zone, they coincide with the plane of the figure); 7 - axes of compression (a) and extension (6) in the subhorizontal (arrow) and subvertical (point) positions in space; 8 - rose-diagram for the strike of the axes of electrically conductive fault zones. 
(a)

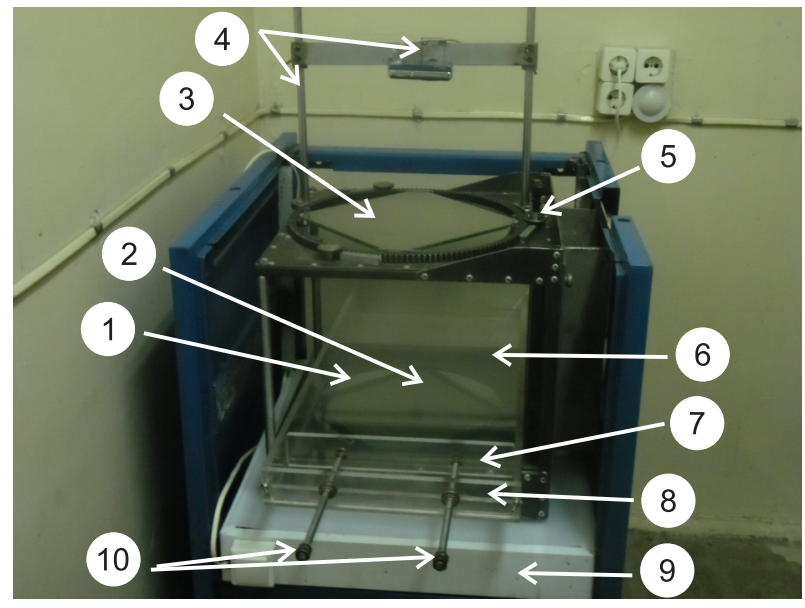

(б)

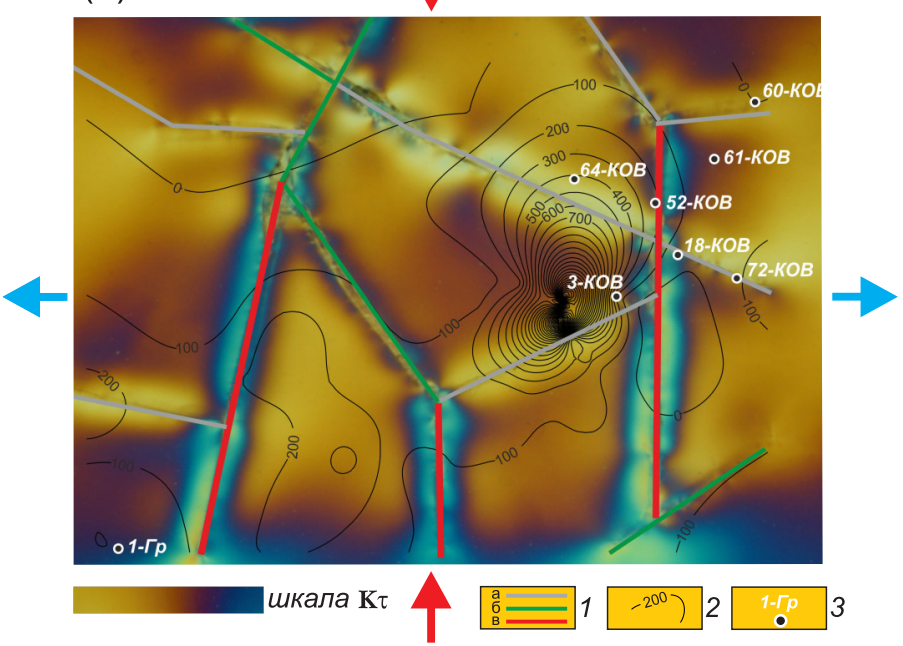

Рис. 8. Оборудование и результаты лабораторного эксперимента по моделированию поля напряжений в осадочном чехле Ковыктинского ЛУ. $(a)$ - полярископ-поляриметр для исследования напряженного состояния в модели из упругого оптически-активного материала: 1 - модель из желатина; 2-3 - поляроиды (2 - поляризатор, 3 - анализатор); 4 - штатив и крепление для фотокамеры; 5 - ручка для синхронного вращения поляроидов; 6-7 - штампы; 8 - плексигласовая ванна для размещения модели; 9 - осветитель (устройство для получения белого света); 10 - винты, регулирующие положение штампа, сжимающего модель; (б) - фотография модели, отражающей распределение коэффициента интенсивности касательных напряжений (Кт) в блоках и разломных зонах Ковыктинского ЛУ применительно к условиям сдвига с меридиональной ориентацией оси сжатия (красные стрелки) и широтной ориентировкой оси растяжения (синие стрелки). 1 - разрывы с низкой (а), средней (б) и высокой (в) степенью активности; 2 - изолинии дебита газа из скважин, м³/сут; 3 - скважины с проявлениями АВПд.

Fig. 8. Laboratory equipment used to model the stress field of the sedimentary cover of the Kovykta LU, and the modeling results. (a) - polariscope-polarimeter for studying the state of stress in the gelatin model (elastic optically active material): 1 - model; 2-3 - polaroids (2 - polarizer, 3 - analyzer); 4 - tripod and fixing gear for the camera; 5 - handle for synchronous rotation of polaroids; 6-7 - stamps; 8 - plexiglass bath for model placement; 9 - illuminator (white light); 10 - screws to adjust the position of the stamp that compresses the model; (б) - photo of the model showing the distribution of the shear stress intensity factor $(\mathrm{K} \tau)$ in the blocks and fault zones of the Kovykta LA in case of strike-slip conditions with the meridional axis of compression (red arrows) and the latitudinal axis of extension (blue arrows). 1 - low (a), medium (б) and highly (B) active faults; 2 - isolines of gas production from wells, $\mathrm{m}^{3} /$ day; 3 - wells showing anomalously high formation pressure (AHFP).

что является существенным дополнением к оценкам, полученным для природного аналога.

Таким образом, тектонофизический подход к анализу разнотипной геолого-геофизической информации по Ковыктинскому ЛУ состоял в выделении разломных зон по материалам морфотектонических, сейсмо- и электроразведочных исследований, а также в физическом моделировании и парагенетическом анализе их сетей, что позволило установить характер и этапность формирования структуры Ковыктинского ГКМ.

\section{3. РЕЗУЛЬТАТЫ ИССЛЕДОВАНИЙ}

Результаты исследований, полученные на Ковыктинсоком ЛУ для верхней и нижней части платформенного чехла, рассматриваются в данном разделе отдельно. Это связано с различием мето- дов и способов выделения разломных зон, которые были использованы для близповерхностных и более глубоко залегающих осадочных комплексов.

\section{1. РАЗЛОМНАЯ СТРУКТУРА И ПОЛЯ НАПРЯЖЕНИЙ В ВЕРХНЕЙ ЧАСТИ ОСАДОЧНОЙ ТОЛЩИ КОВЫКТИНСКОГО ЛУ}

Основными методами изучения характера дислоцированности верхней части платформенного чехла были линеаментный анализ рельефа с заверкой результатов данными физического моделирования и, в меньшей степени, прямые геологоструктурные наблюдения вследствие слабой обнаженности пород на платформенной территории.

Результатом линеаментного анализа рельефа является схема его спрямленных элементов, послужившая основой для выделения разломных зон (рис. 9, a). Из нее следует, что выявленные элементы рельефа распределяются на Ковыктинском ЛУ 


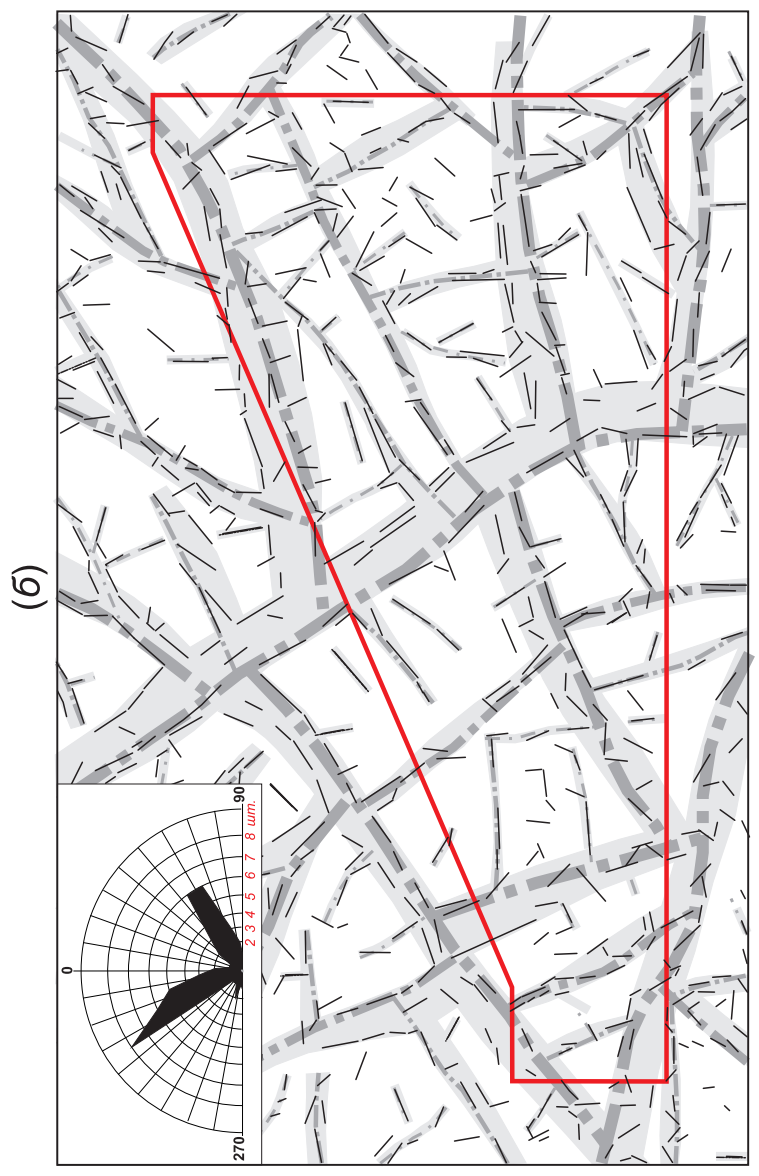

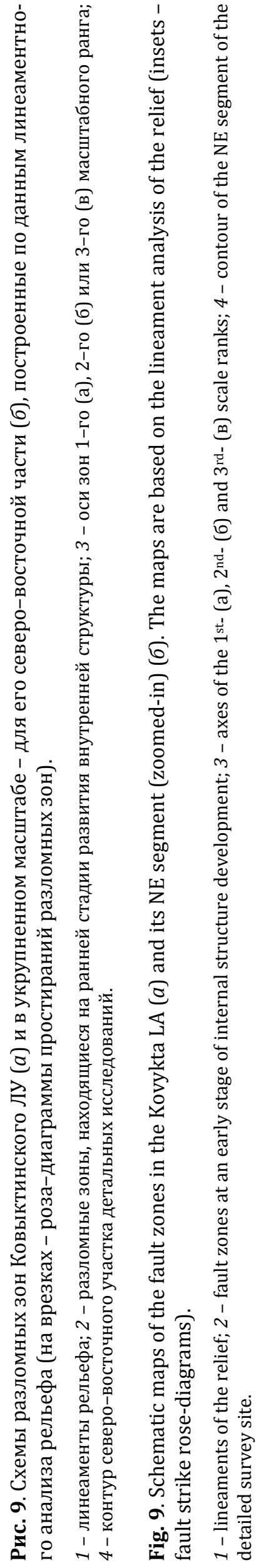

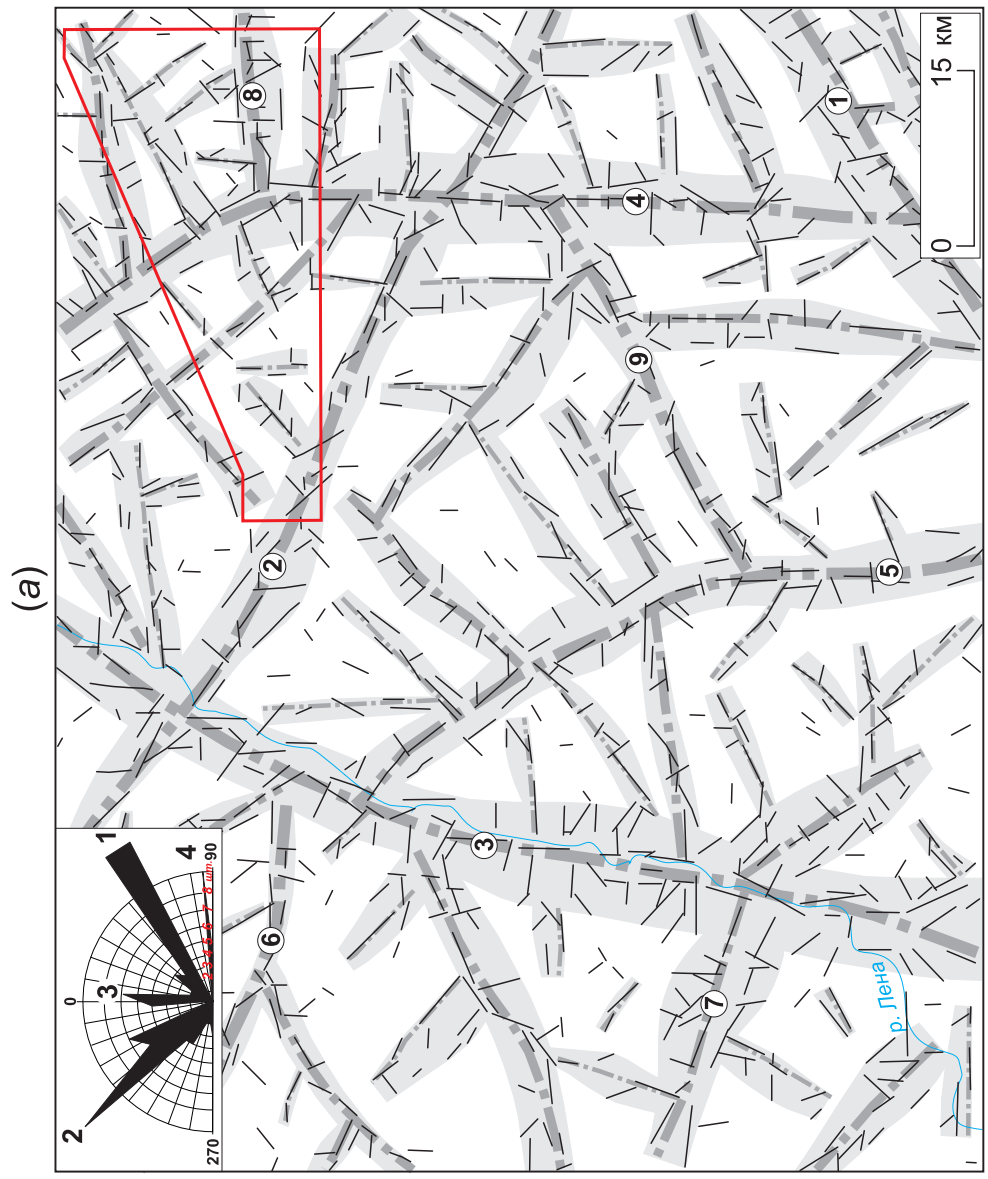


неравномерно, образуя зоны сгущения близко расположенных, часто субпараллельных, сравнительно коротких линеаментов. Даже если не отождествлять все выделенные линеаменты с тектоническими разрывами, зоны их повышенной плотности с большой долей уверенности следует относить к разломным. Многие из них совпадают с долинами рек, которые, как известно, подчеркивают ослабленные, наиболее нарушенные участки земной коры. В соответствии с тектонофизическими представлениями, это дизъюнктивы, внутреннее строение которых соответствует ранней стадии развития (см. рис. 1, б) и выражено в платформенном чехле сетью опережающих разрывов 2-го порядка. Магистральный сместитель (разрыв 1-го порядка) у большинства подобных структур не сформировался вследствие слабой тектонической активности платформенного региона.

Составленная схема отчетливо свидетельствует о зонно-блоковом характере дислоцированности верхней части осадочного чехла на Ковыктинском ЛУ (рис. 9, $a$ ), причем выделенная структура характеризуется иерархической соподчиненностью составляющих ее элементов. Соотношения поперечных размеров, а также пространственные взаимоотношения наиболее протяженных зон позволяют разделить их в первом приближении на три масштабных ранга. Наиболее крупные разломные зоны 1-го ранга соответствуют тем структурам, которые ранее были выявлены при изучении Иркутского амфитеатра в целом (см. рис. 2, $a$ ). Зона 1 характеризуется северо-восточным простиранием и является одной из главных составляющих сети разрывов Жигаловского вала. Зона 2, простираясь на северо-запад, пересекает лицензионный участок и трассируется далее в центр Иркутского амфитеатра. Зоны 3, 4 и 5 имеют в целом субмеридиональную ориентировку и являются причиной формирования наиболее крупных для региона речных долин (реки Лена, Орлинга, Чичапта). Зоны 6, 7 и 8 характеризуются субширотной ориентировкой и располагаются на периферии лицензионного участка. Перечисленные структуры создают на изучаемой территории основу разломной сети, представляя каждую из четырех главных систем, выделяющихся в его пределах (см. врезку на рис. 9, $a$ ).

Крупные зоны характеризуются в плане существенными размерами и представлены сгущением десятков линеаментов. Это позволило для определения их морфогенезиса и динамических обстановок формирования использовать парагенетический анализ с построением роза-диаграмм и применением соответствующих трафаретов (см. рис. 4,2$)$. Результаты анализа, примененного для всех выявленных на Ковыктинском ЛУ девяти дизъюнктивных структур 1-го ранга, иллюстриру- ются на примере зоны 1 (рис. 10). На роза-диаграмме разрывов (рис. 10, б), составляющих внутреннюю структуру зоны 1 (рис. 10, a), выделяется пять систем. Система 1 включает наибольшее количество разрывов и по простиранию соответствует ориентации зоны 1 и Жигаловского вала в целом. Это послужило основанием для совмещения с ней системы Ү-сколов магистрального сместителя в эталонных парагенезисах разрывов 2-го порядка для каждого из четырех возможных типов разломных зон: сброса, формирующегося в условиях растяжения в направлении СЗ-ЮВ (рис. 10, в), взброса с аналогичным направлением сжатия (рис. 10,2$)$ и сдвигов, образующихся в поле напряжений с субмеридиональным и субширотным положением горизонтальных осей сжатия и растяжения, взаимная ориентация которых определяет право- (рис. 10, $\partial$ ) или левосторонний (рис. $10, e$ ) характер перемещения крыльев.

Сопоставление анализируемых вариантов показало, что практически полным является совпадение лучей роза-диаграммы с эталоном левого сдвига (рис. 10,e). Данным типом подвижек в разломной зоне 1 может быть объяснено происхождение всех пяти систем при слабом совпадении системы 5 с ориентацией взбросов t-типа. Каждый из трех оставшихся эталонных парагенезисов может объяснить происхождение только трех или с некоторой «натяжкой» четырех (рис. 10, в) систем разрывов. Следовательно, проведенный анализ свидетельствует о существовании в истории формирования разломной зоны 1 левосдвигового этапа развития с ориентацией субгоризонтальной оси сжатия в меридиональном, а оси растяжения - в субширотном направлении. Возможной является активизация дизъюнктива в трех других рассмотренных обстановках, из которых наиболее вероятно растяжение в направлении СЗ-ЮВ (рис. 10, в).

Аналогичный анализ, проведенный для других крупных зон Ковыктинского ЛУ, показал, что для объяснения происхождения всех выделенных в их пределах систем разрывов 2-го порядка необходимо в каждом случае существование одной или двух разнотипных динамических обстановок. Главные из них привели к подвижкам сбросового или левосдвигового типа. На общей диаграмме видно (рис. 11,a), что для субмеридиональных зон 3,4 и 5 наиболее выраженным являлся этап растяжения, а для остальных зон - левого сдвига с различной ориентировкой осей напряжений, так как три из них (2, 6 и 7) простираются в северо-западном, две другие (1 и 9) - в северо-восточном и еще одна (8) в широтном направлении. Это свидетельствует о том, что сеть крупных разломных зон Ковыктинского ЛУ должна была формироваться как минимум в двух разновозрастных полях региональных 

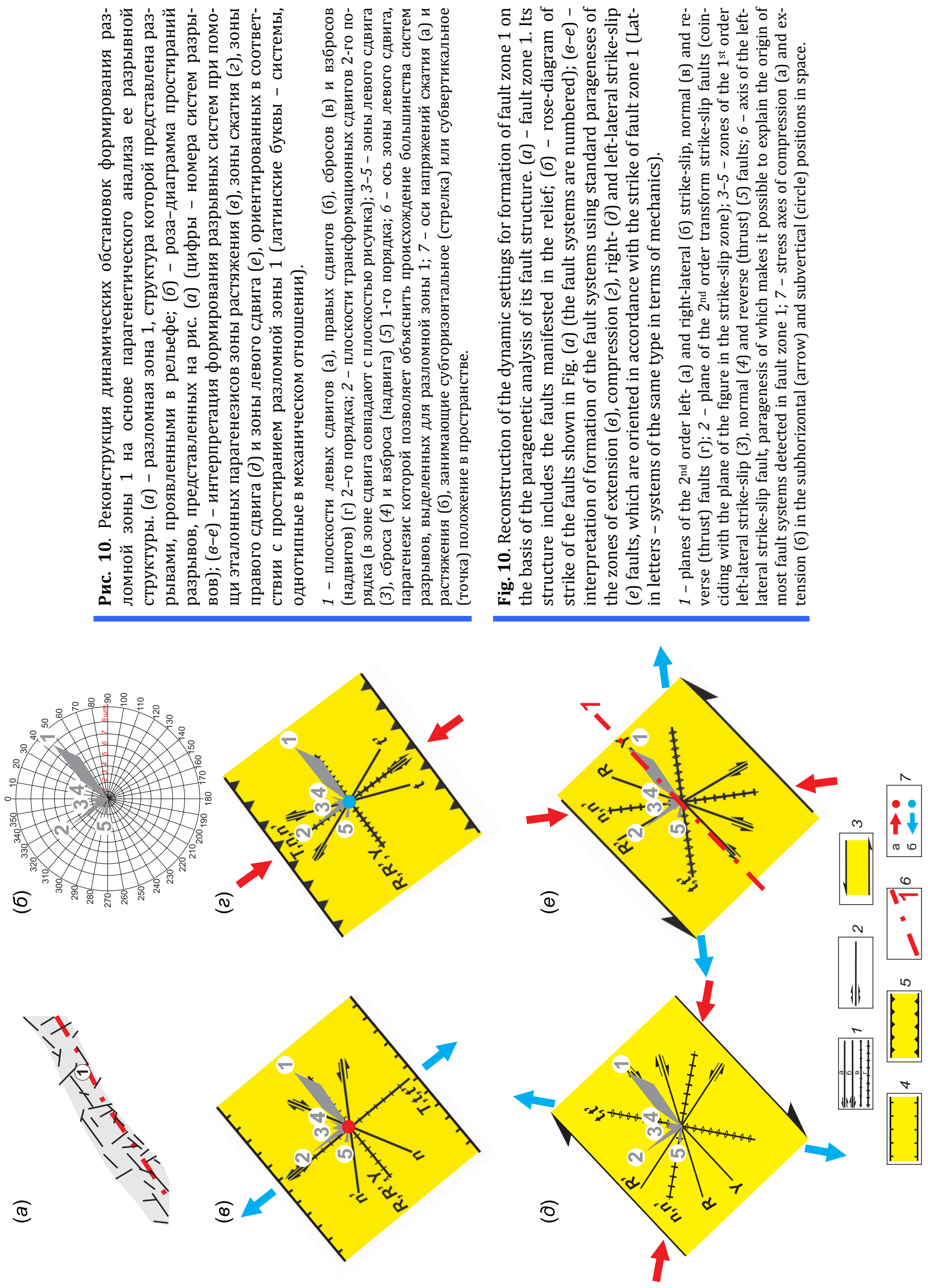

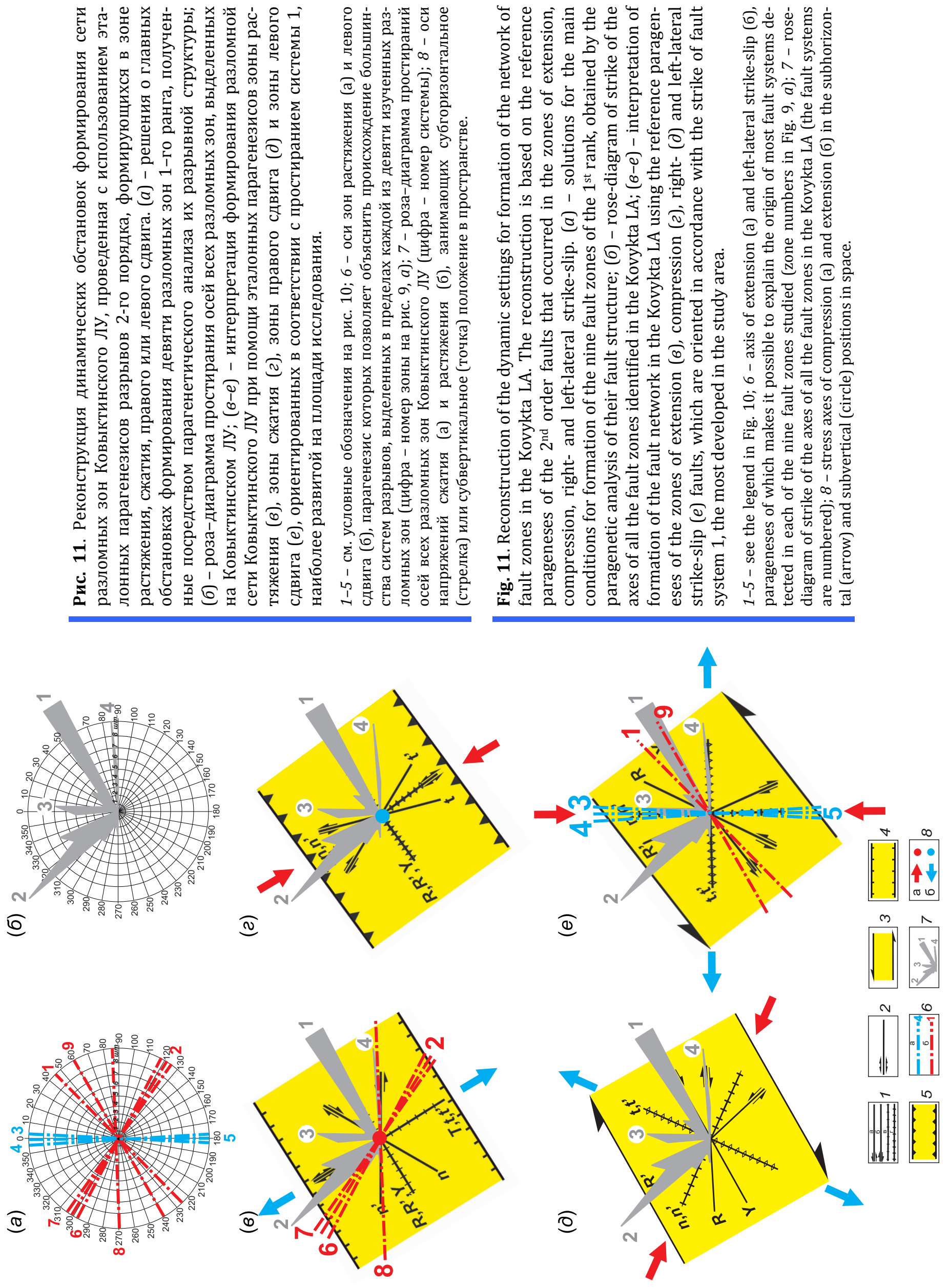
напряжений. Одним из них является растяжение в направлении СЗ-ЮВ (рис. 11, в), а другим - поле сдвига с субмеридиональной ориентировкой оси сжатия и субширотной ориентировкой оси растяжения (рис. $11, e$ ).

Данный вывод подтверждают результаты парагенетического анализа сети разломных зон Ковыктинского участка в целом, реализованного на основе роза-диаграммы простираний их осей (рис. 11, б). Сопоставление ориентировки систем разломных зон с эталонными парагенезисами разрывов, образующихся в условиях растяжения (рис. 11, в), сжатия (рис. 11,2$)$, правого (рис. $11, \partial$ ) и левого (рис. $11, e)$ сдвига, показало, что вся их совокупность могла сформироваться в обстановке сдвига, в соответствии с которой наиболее развитые на участке направления разрывных структур характеризовались левосторонними (для северо-восточных зон) или правосторонними (для северо-западных зон) типами подвижек. При этом субмеридиональные структуры являлись сбросами, а субширотные взбросами (или надвигами). Остальные динамические обстановки объясняют происхождение трех (растяжение на рис. 11,8 ; правый сдвиг на рис. 11 , д) или двух (сжатие на рис. 11, 2) из выделенных систем.

Таким образом, парагенетический анализ показал, что на Ковыктинском ЛУ проявились как минимум два этапа тектогенеза: I - растяжение с ориентацией активной оси в направлении СЗ-ЮВ (рис. 11, в); II - сдвиг с меридиональной ориентировкой оси сжатия и широтным простиранием оси растяжения (рис. $11, e$ ). Рис. 12 иллюстрирует те разломные зоны, которые могли быть активны на каждом из выявленных этапов согласно эталонным парагенезисам разрывов, соответствующим каждой из рассматриваемых динамических обстановок. Для зон 1-го ранга они подтверждаются по главным решениям парагенетического анализа (рис. $12,8, e)$, тогда как для зон 2-го и 3-го рангов кинематика движений является прогнозной.

Результаты физического моделирования в целом подтвердили главные закономерности разломной тектоники Ковыктинского ЛУ, установленные в ходе парагенетического анализа (см. рис. 8, б). Упругая модель с разрывами, нанесенными согласно выделенной для природного объекта сети разломов 1-го ранга, подвергалась деформации в поле сдвига (II), так как именно эта динамическая обстановка была установлена для Ковыктинского ЛУ с наибольшей достоверностью. Как видно из рис. 8, б, изменение концентрации напряжений вблизи разрывов происходит в широких зонах, размер которых зависит от степени активности нарушения. Анализ цветовой картины, отражающей увеличение интенсивности напряжений при переходе от светлых к более темным тонам, свидетельствует, что разломы и их сегменты могут иметь низкую, среднюю или высокую активность. Наиболее активными в рассматриваемом поле напряжений являются субмеридиональные зоны, а наименее активными - разломы субширотной ориентировки.

Полученные материалы, с одной стороны, подтверждают, а с другой - уточняют природные оценки, согласно которым зоны делились только на две группы - активные и неактивные (рис. 12, a). Более того, они позволяют проанализировать напряженное состояние в блоках, которым свойственно неравномерное распределение стресса, обусловленное характером активности ограничивающих их разрывных структур. Сопоставление полученной картины с продуктивностью (изолинии) и проявлением аномально высоких пластовых давлений (черные точки) в скважинах Ковыктинского ЛУ показывает, что в первом приближении области повышенных дебитов тяготеют к пониженным концентрациям напряжений, а АВПД - к местам их повышения и к градиентным областям. Эти наблюдения носят предварительный характер и в дальнейшем должны уточняться в ходе целенаправленной серии экспериментов, базирующихся на детализированной схеме разломной сети и углубленных представлениях об этапах ее формирования.

Результатами геолого-структурных, сейсмологических и геомеханических исследований являлись решения о типе стресс-тензоров, полученных в отдельных точках Ковыктинского ЛУ и, главным образом, его окрестностей. Они обобщены на рис. 13 и в целом хорошо согласуются между собой. Реконструкции, полученные при обработке измерений тектонической трещиноватости в разломах, связанных с проявлениями складчатых деформаций палеозойского возраста (рис. 14, a), указывают на господство региональных условий сжатия в СЗ-ЮВ направлении. Стресс-тензоры, восстановленные по трещиноватости в зонах активных неотектонических разломов и в слабосцементированных осадках (рис. 14, б), свидетельствуют, что для кайнозойского этапа развития территории характерно растяжение с СЗ-ЮВ направлением минимального горизонтального сжатия и, соответственно, СВ-ЮЗ направлением оси максимального горизонтального сжатия (см. рис. 13).

Использование сейсмологических данных позволяет оценить тип современного напряженного состояния коры в пределах исследуемой части Сибирской платформы. С этой целью был проведен анализ стресс-тензоров, обобщенных для центральной части и юго-западного фланга Байкальского рифта [Petit et al., 1996; Sankov, Dobrynina, 

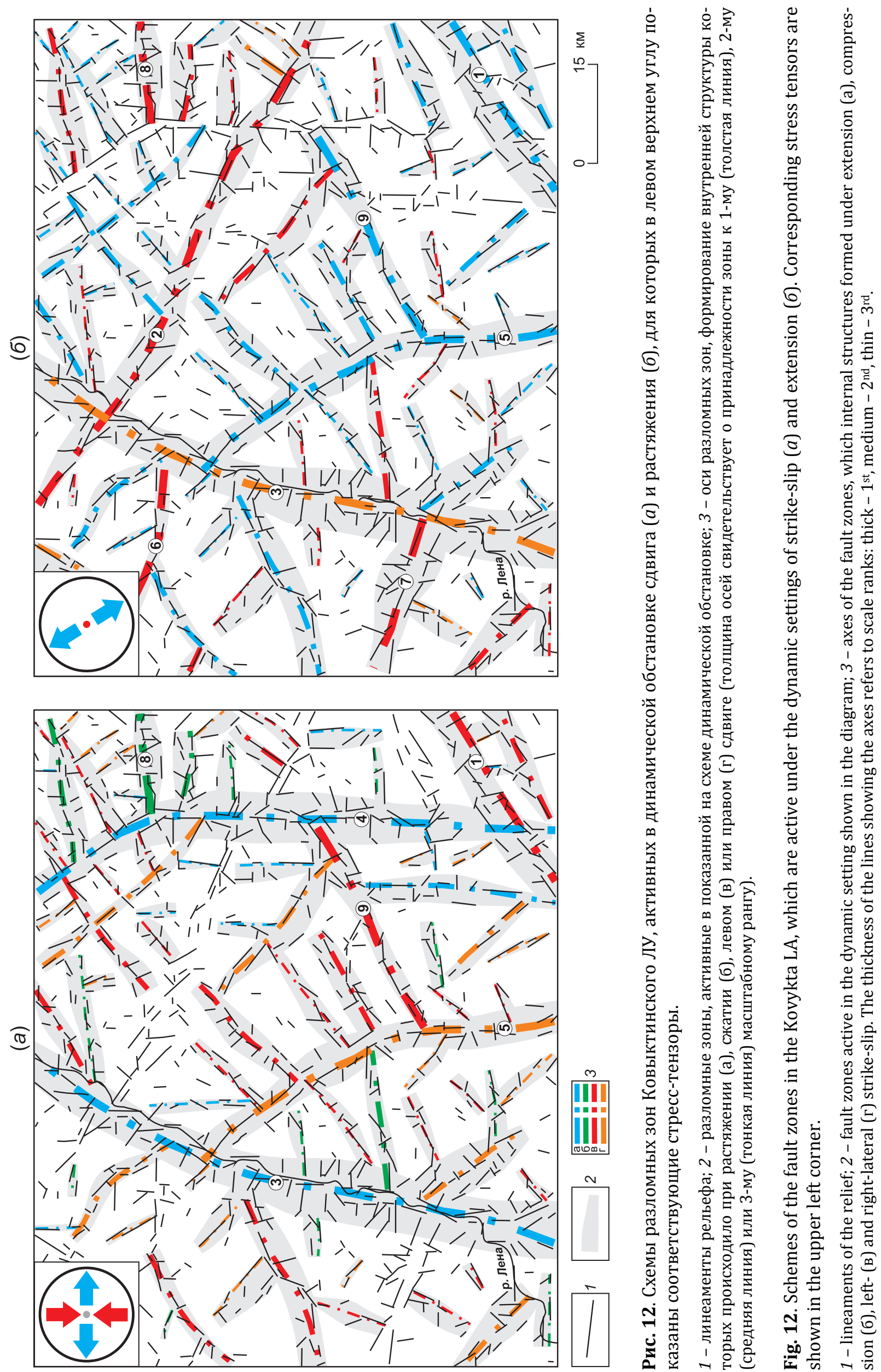

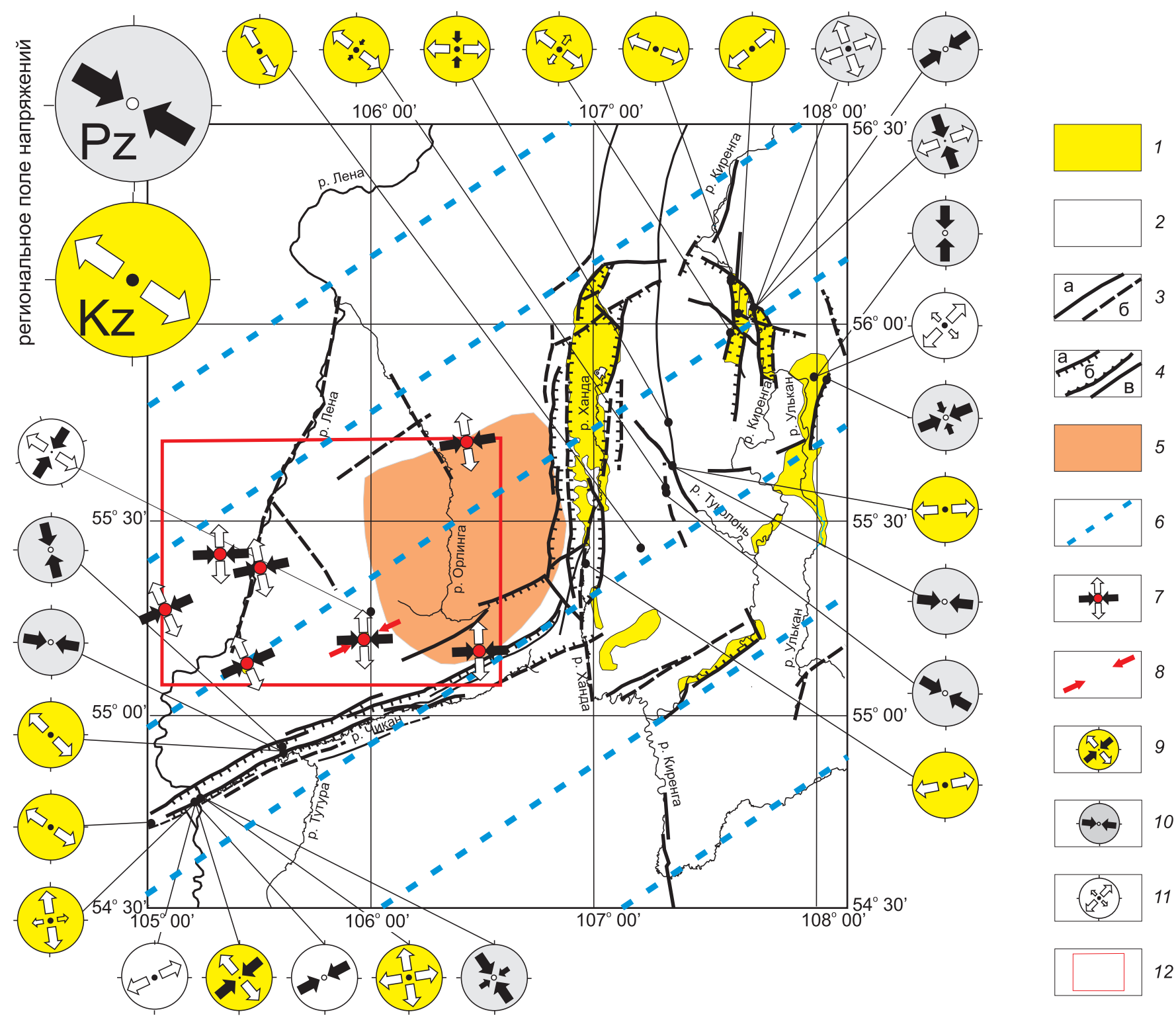

Рис. 13. Региональные и локальные поля тектонических напряжений неотектонического и современного этапов в районе Ковыктинского ЛУ.

1 - кайнозойские впадины; 2 - палеозойский чехол Сибирской платформы; 3 - разломы неотектонической активизации: а установленные, б - предполагаемые; 4 - кинематические типы разломов: а - сбросы, б - взбросы, в - неизвестной кинематики; 5 - область локального поднятия вершинной поверхности Н>1000 м; 6-11 - напряженное состояние земной коры: 6 - траектории максимального горизонтального сжатия по сейсмологическим данным, 7 - направления максимального (черное) и минимального (белое) напряжений по данным кавернометрии, 8 - направления максимального сжатия по данным сейсмической локации очагов эмиссии при гидроразрыве, 9-11 - стресс-тензоры поля напряжений по геолого-структурным данным: 9 - кайнозойского возраста (черные стрелки - максимальное горизонтальное сжатие, белые - минимальное горизонтальное сжатие), 10 - палеозойского возраста, 11 - неизвестного возраста; 12 - Ковыктинский ЛУ.

Fig. 13. Regional and local tectonic stress fields at the neotectonic and modern stages of the Kovykta LA.

1 - Cenozoic depressions; 2 - Paleozoic nappe of the Siberian platform; 3 - faults of neotectonic activation: a - confirmed, 6 - assumed; 4 kinematic types of faults: a - normal, 6 - reverse, в - unknown kinematics; 5 - local uplift (H>1000 m); 6-11 - stress state of the crust: 6 trajectories of maximum horizontal compression from seismological data, 7 - directions of maximum (black) and minimum (white) stresses according to caliper data, 8 - directions of maximum compression from seismic location data of the emission foci during hydrofracturing, 9-11 - stress tensors from the geostructural data: 9 - Cenozoic age (black arrows - maximum horizontal compression, white arrows - minimal horizontal compression), 10 - Paleozoic age, 11 - unknown age; 12 - Kovykta LA.

2018], и результатов экстраполяции осредненных параметров механизмов очагов [Headbach et al.,
2010]. Интерполяция всех этих данных с результатами определения фокальных механизмов для 
(a)
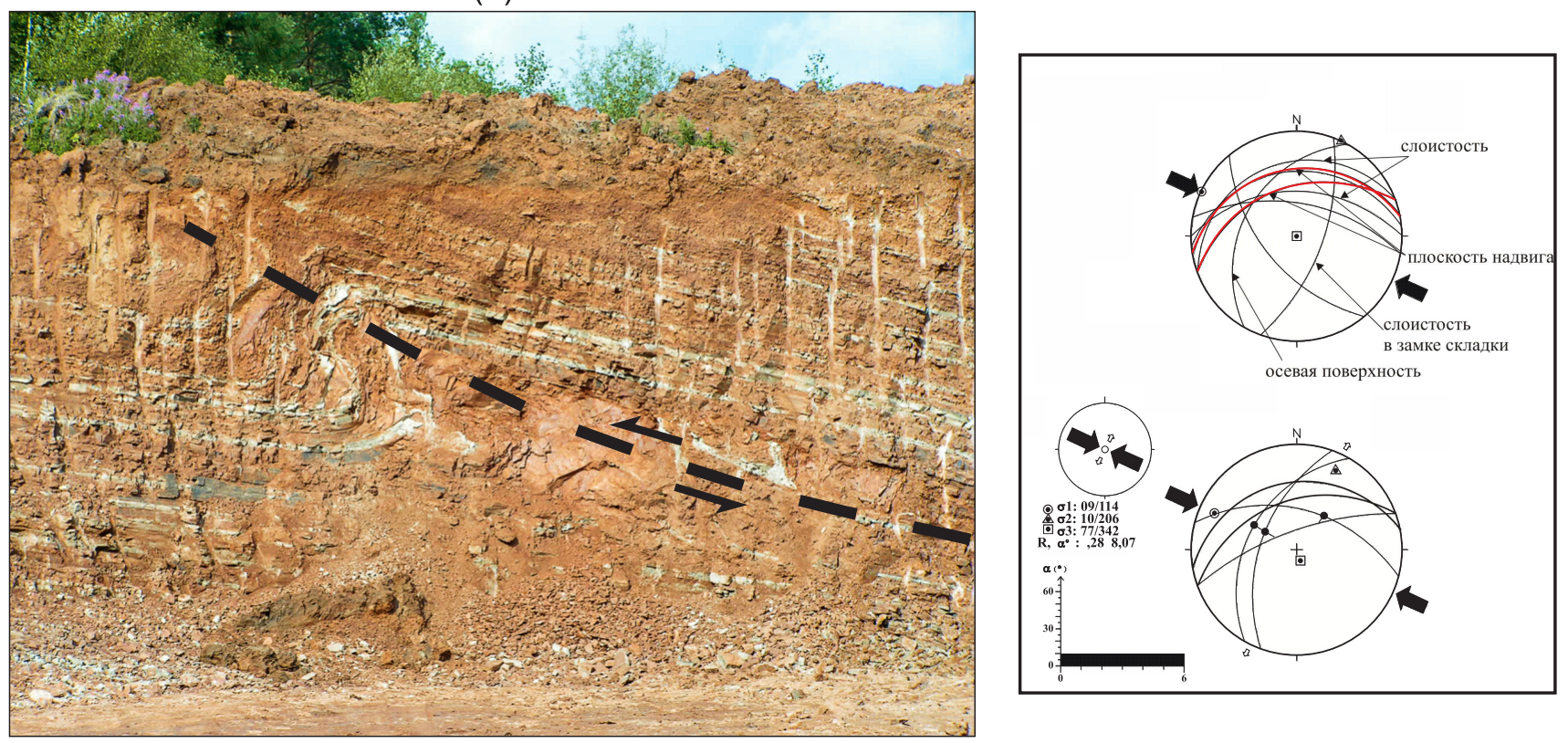

(б)
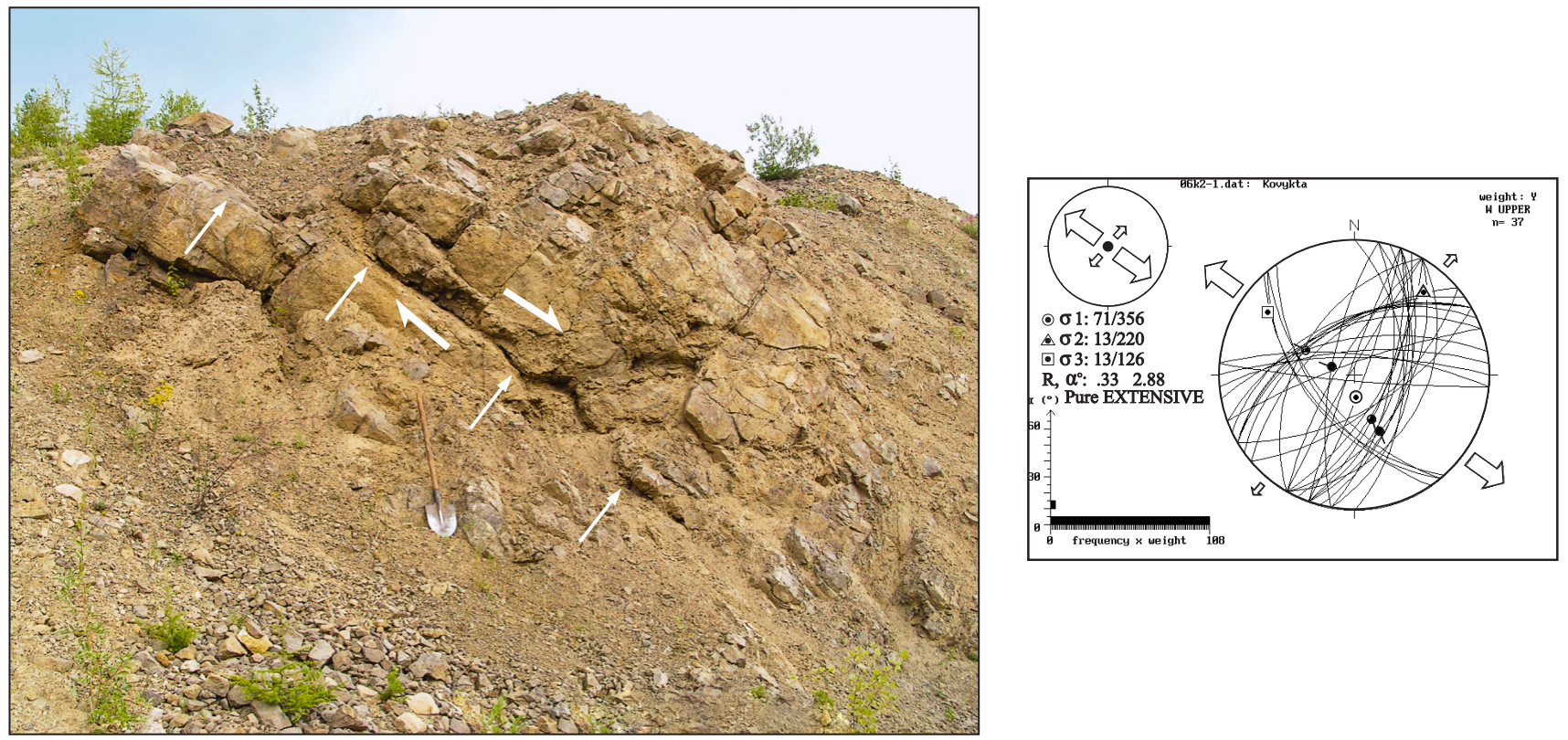

Рис. 14. Примеры реконструкций стресс-тензоров палеозойского сжатия (a) и кайнозойского растяжения (б) в направлении СЗ-ЮВ по геолого-структурным данным (справа даны результаты реконструкций с использованием методики [Delvaux, 1993]). (a) - антиклинальная складка в красноцветных терригенных отложениях верхоленской свиты верхнего кембрия, осложненная надвигом северовосточного простирания; (б) - один из разрывов (аз. пад. $140^{\circ} \angle 55^{\circ}$ ) зоны бортового разлома Балдахинской впадины.

Fig. 14. Examples of the reconstructed stress tensors of Paleozoic compression $(a)$ and Cenozoic extension (б) in the NW-SE direction from the geostructural data (on the right are the reconstructions by the method described in [Delvaux, 1993]). (a) - anticlinal fold in the red-coloured terrigenous deposits of the Verkholenskaya suite of the Upper Cambrian, complicated by the NE-striking thrust; (б) - one of the fractures (dip az. $140^{\circ} \angle 55^{\circ}$ ) in the zone of the border fault of the Baldakhin depression.

двух платформенных землетрясений (26.02.1996 г., К=11.6, и 17.01.2014 г., К=13.3 [Melnikova, Radziminovich, 1998; Seredkina et al., 2015]) позволяет за- ключить, что ось максимального горизонтального сжатия современного поля напряжений на уровне средней части коры в пределах Иркутского амфи- 
театра имеет северо-восточное простирание (см. рис. 13). Соответственно, в общем случае ось минимального горизонтального сжатия (растяжения) имеет северо-западное направление. Сопоставление этих данных с материалами, полученными в рамках геомеханических исследований по Ковыктинскому ЛУ, показывает как совпадение, так и некоторые отклонения от регионального тренда (см. рис. 13). Авторы этих исследований предполагают, что локальные изменения направления максимального горизонтального сжатия обусловлены осложнениями тектонического плана, а также ответной реакцией гетерогенной среды компетентных толщ осадочного чехла. Условия деформирования, являющиеся причиной подобных отклонений, будут рассмотрены в следующем разделе статьи для детального участка исследований на северо-востоке Ковыктинской площади.

В целом тектонофизический подход к интерпретации разнотипных геолого-геофизических материалов свидетельствует, что в верхней части осадочного чехла структура Ковыктинского ГКМ представляет иерархию блоков и окружающих их широких интенсивно нарушенных зон. В традиционной трактовке это зоны повышенной трещиноватости или скрытых разломов фундамента, которые с позиций тектонофизики представляют ранние стадии развития разломов. В истории их формирования выделяется два главных временных этапа, каждому из которых соответствует определенная динамическая обстановка регионального ранга. Палеозойский этап, установленный по геолого-структурным данным в окрестностях Ковыктинского ЛУ, характеризовался полем сжатия коры в направлении СЗ-ЮВ. В кайнозойское время сеть разломных зон развивалась в двух главных динамических обстановках: при сдвиге с меридиональной ориентацией оси сжатия и широтной - оси растяжения, а также в условиях северо-запад-юговосточного растяжения, соответствующего современному полю напряжений Байкальского рифта. Активность разломных зон и распределение напряжений в блоках в каждом из этих полей характеризуются ярко выраженной неравномерностью, которая, судя по предварительным результатам физического моделирования, оказывает определенное влияние на проявления аномально высоких пластовых давлений и дебит газа в скважинах Ковыктинского ЛУ.

\section{2. РАЗЛОМНАЯ СТРУКТУРА И ПОЛЯ НАПРЯЖЕНИЙ В НИЖНЕЙ ЧАСТИ ОСАДОЧНОЙ ТОЛЩИ КОВЫКТИНСКОГО ЛУ}

Характер дислоцированности нижней части платформенного чехла изучался посредством применения тектонофизического подхода к интерпре- тации материалов детальных сейсмо- и электроразведочных работ, проведенных на Ковыктинской площади для солевого и подсолевого комплексов. Участки съемок различаются по размерам и форме (см. рис. 3, a), но перекрываются в пределах площадки треугольной формы, которая стала полигоном для сопоставления результатов разнотипных исследований.

Данные сейсморазведки представляют наиболее емкую информацию, использованную при тектонофизическом анализе строения Ковыктинского ЛУ. Как отмечалось ранее, для его северо-восточной части с использованием всего диапазона времен сейсмической записи был построен куб совокупного атрибута, на основе которого выделялись разрывы. Вероятно, не все они являются геологическими разломами, однако существование последних - главная причина наиболее крупных из выделяющихся сейсмонеоднородностей, что подтверждается визуальным анализом профилей (см. рис. 6, $a$ ).

Схема (см. рис. 6, б) отчетливо иллюстрирует существование зон сгущения разрывов, между которыми породный массив практически не нарушен. Таким образом, в данном случае можно сделать вывод о существовании зонно-блоковой структуры, которая, если судить по степени замкнутости разломной сети, находится на ранней стадии формирования. Как видно из карты плотности разрывов в изолиниях (рис. 15, б), ее главным элементом является широкая полоса максимальных значений параметра. Она имеет в плане дугообразную форму с субмеридиональным центральным сегментом Большеириньским валом - и концевыми ответвлениями, из которых северный простирается в северо-восточном, а южный - в юго-восточном направлении.

На примере северо-восточного полигона показано (зеленый штрихпунктир на рис. 15, б), что более мелкие зоны могут быть выделены в виде полос повышенной плотности разрывов и/или цепочек максимумов данного параметра. В тех случаях, когда присутствуют оба признака, зоны выделяются однозначно. Примером здесь могут служить субмеридиональные структуры, которые в совокупности представляют Большеириньский вал. Менее достоверным является трассирование разломных зон только по максимумам, как это, например, характерно для запад-северо-западного нарушения в центре полигона детальных исследований. Судя по роза-диаграмме (рис. 15, a), оси выделенных зон повышенной плотности разрывов образуют на северо-восточном полигоне пять систем. Проведенный с учетом доминирования северовосточной системы парагенетический анализ показал, что для данного участка на основе проанали- 


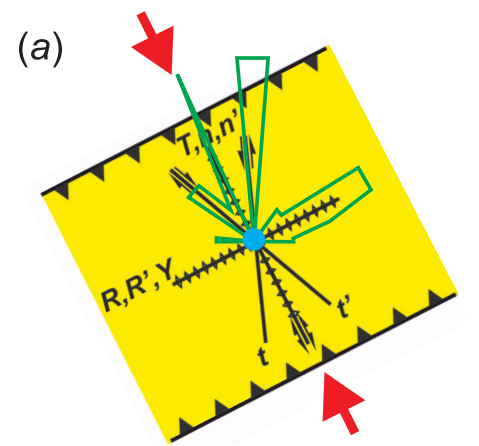

(б)
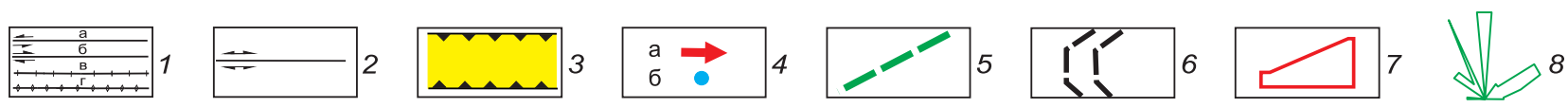

Рис. 15. Результаты тектонофизического анализа сети разрывов, выявленных по данным сейсморазведки на востоке Ковыктинского ЛУ. (a) - поле напряжений, реконструированное парагенетическим методом по сети разломных зон, представляющих полосы сгущения разрывов, выделенных из куба когерентности на северо-восточном участке детальных исследований; (б) - карта плотности разрывов со схемы рис. 6, б, попадающих в ячейку размером $1 \times 1$ км (значения плотностей показаны в разрывах изолиний). Зеленый пунктир - оси зон повышенной плотности.

1-2 - см. на рис. 10; 3 - зона сжатия 1-го порядка; 4 - положение субгоризонтальной оси сжатия (а) и субвертикальной оси растяжения (б); 5 - оси зон повышенной плотности разрывов на северо-восточном участке; 6 - крупная полоса повышенной плотности разрывов; 7 - контур северо-восточного участка детальных исследований; 8 - роза-диаграмма простираний осей зон повышенной плотности разрывов на северо-восточном участке.

Fig. 15. Results of the tectonophysical analysis of the network of faults identified from the seismic data on the eastern segment of the Kovykta LA. $(a)$ - stress field reconstructed by the paragenetic method from the network of fault zones represented by the bands of closely spaced fractures identified from the coherence cube in the NE segment of the detailed survey site; (б) - fracture density map from the schematic map shown in Fig. 6, б (1 km $\times 1 \mathrm{~km}$ cell) (the density values are shown at isolines). Green dashed lines - axes of high density zones.

1-2 - see Fig. 10; 3 - 1st order compression zone; 4 - positions of the axes of subhorizontal compression (a) and subvertical extension (б); 5 - axes of the zones with increased density of fractures in the NE segment; 6 - large band of increased density of fractures; 7 - contour of the NE segment of the detailed survey site; 8 - rose-diagram of strike of the axes of the zones with increased density of fractures in the NE segment. 
зированного материала с наибольшей достоверностью восстанавливается обстановка сжатия в направлении СЗ-ЮВ.

Детализация напряженного состояния была осуществлена на основе анализа базы данных с элементами залегания (азимут и угол падения) всех разрывов, выделенных при обработке куба когерентности (см. рис. 6, б). Восточный участок Ковыктинской площади был разделен на 26 локальных ячеек, имеющих в плане квадратную форму с длиной стороны 8 км. Количество разрывов в каждом объеме с горизонтальным сечением такого размера составило от 49 до 374, что приемлемо для построения круговых диаграмм и их анализа в рамках метода спецкартирования [Seminsky, 2014, 2015]. Из 26 ячеек две (13 и 24) были прямоугольными, так как к квадратам добавлялись небольшие площадки на краях участка, в пределах которых небольшое количество разрывов (менее 10) не могло составить полноценную самостоятельную выборку.

Круговые диаграммы разрывов, построенные для каждой ячейки (рис. 16, a), а также решения о поле напряжений (рис. 16, б), полученные в результате наложения на диаграммы эталонных трафаретов (рис. 16, a), позволяют сделать два главных вывода.

Во-первых, разрывная сеть практически повсеместно характеризуется простым строением. Доминируют две-три, реже четыре системы, причем их простирание слабо варьируется в пределах локального объема. Нарушения простираются главным образом в северо-восточном направлении с вариациями до субмеридиональной и субширотной ориентировок. Единичные разрывы северо-западной и близких к ней ориентировок практически отсутствуют, хотя зоны сгущения разрывов подобного простирания выделяются отчетливо (см. рис. 15). Причинами столь редко встречающегося, избирательного распределения единичных разрывов по сторонам света может быть «потеря» части разрывов на стадиях сбора или обработки сейсморазведочной информации, а также высокая текучесть насыщенной солями осадочной толщи, в которой отчетливо проявляются разрывы наиболее интенсивных этапов тектогенеза, а другие дислокации сравнительно быстро «залечиваются» пластичным субстратом.

Во-вторых, практически все реконструированные для изученной разрывной сети стресс-тензоры свидетельствуют об обстановке сжатия, реже сдвига при полном отсутствии обстановок растяжения (рис. 16, б). Доминирующие стресс-тензоры сжатия делятся на две группы, в одной из которых активная ось занимает субширотное, а в другой северо-западное положение. Пространственное распределение выявленных полей характеризуется отчетливыми закономерностями, если принять во внимание наличие широкой дугообразной полосы повышенной плотности разрывов, показанной на рис. 15 , б. Для меридионального сегмента этой полосы - Большеириньского вала - характерно поле субширотного сжатия, для простирающегося на северо-восток северного отрезка - правый сдвиг, а для ориентированного в юго-восточном направлении южного сегмента - левый сдвиг (рис. 16, б). Эта совокупность стресс-тензоров располагается в поле сжатия с ориентацией одноименной оси в направлении СЗ-ЮВ.

Полученные реконструкции позволяют установить стиль дислоцированности солевого и, частично, подсолевого комплексов, т.е. той части осадочной толщи, для которой по данным сейсморазведки была выявлена изученная выше сеть разрывов (рис. 16, б). Доминирующая на участке обстановка сжатия пород в направлении СЗ-ЮВ осложняется в его центре структурой течения, образовавшейся в условиях субширотного стресса. Под давлением с востока породы галогенно-карбонатного комплекса перемещались на запад в виде сравнительно единого покрова, имеющего в плане клинообразную форму. Поскольку общий наклон напластования не превышает первых единиц градуса к северозападу, формально эта пластина не является надвигом, поскольку движется практически по направлению падения. Вместе с тем она обладает всеми признаками аллохтона. Ее движение сопровождалось деформациями сдвига на северной и южной границах, а также интенсивного сжатия - во фронтальной части, что в конечном итоге привело к образованию Большеириньского вала. В подсолевом комплексе он не проявлен в виде единой явно выраженной структуры. Соответственно, в отличие от сжатия в направлении СЗ-ЮВ, поле напряжений с широтной ориентацией оси сжатия для нижней части осадочного разреза не характерно.

Данные электроразведки представляют независимую геофизическую информацию о характере флюидонасыщенной разломной структуры солевого и подсолевого комплексов в пределах северо-восточного полигона детальных исследований. Как видно на примере христофоровско-балыхинского горизонта (см. рис. 7, a), участки повышенной электропроводности характеризуются линейно вытянутой формой и системным расположением в плане. Некоторые из них проявляются в смежных слоях, а наиболее крупные трассируются через все изученные горизонты. Это позволяет предположить, что рассматриваемые зоны имеют разломное происхождение. Они отличаются от окружающей толщи повышенной нарушенностью трещинами и мелкими разрывами, что при высокой флюидонасыщенности межсолевых карбонатных трещинных резер- 


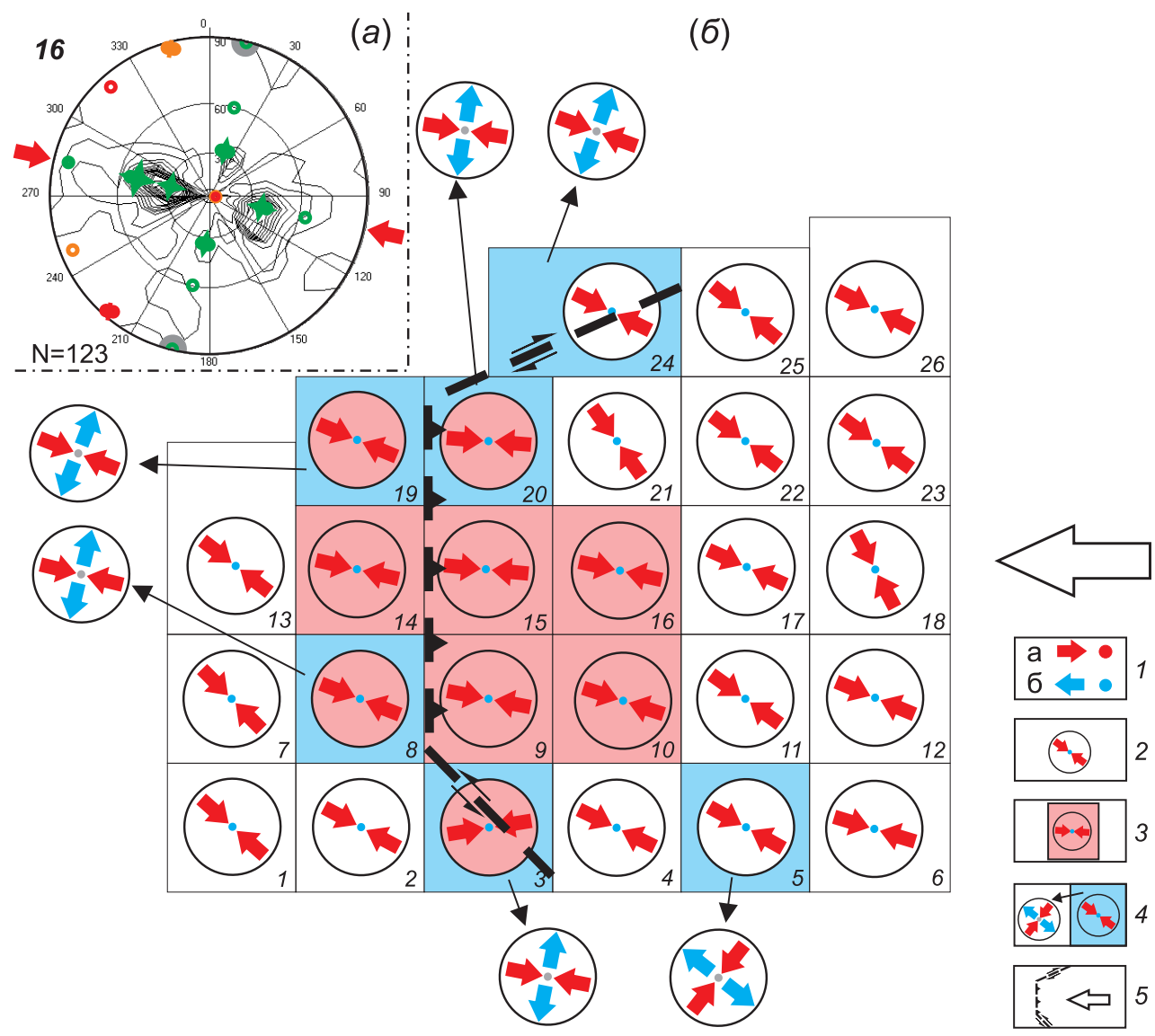

Рис. 16. Детализация напряженного состояния нижней части осадочной толщи на востоке Ковыктинского ЛУ посредством парагенетического анализа сетей разрывов для 26 локальных объемов в его пределах. (a) - пример реконструкции поля сжатия для ячейки 16, полученной при совмещении построенной для нее круговой диаграммы разрывов с эталонным трафаретом (см. «взброс-50» на рис. 4, a); (б) - карта стресс-тензоров, восстановленных по примеру рис. 16, a, для каждого из 26 локальных объемов на участке исследований.

1 - оси напряжений сжатия (а) и растяжения (б), занимающие субгоризонтальное (стрелка) или субвертикальное (точка) положение в пространстве; 2-3 - ячейки, для которых реконструированы стресс-тензоры сжатия в направлении СЗ-ЮВ (2) и в направлении В-3 (3); 4 - ячейки, в которых, кроме обстановки сжатия, реконструирована обстановка сдвига (соответствующий стресс-тензор вынесен за границы участка исследований); 5 - ось крупной зоны деформаций солевого комплекса, образовавшейся при субширотном сжатии (стрелка) и состоящей из трех кинематически связанных сегментов: северного - правый сдвиг, центрального - сжатие, южного - левый сдвиг.

Fig. 16. Detailed stress state of the lower part of the sedimentary strata in the eastern segment of the Kovykta LA by the paragenetic analysis of the fracture networks for 26 local volumes. (a) - example of the reconstructed compression field for cell 16, obtained by combining the circular diagram of the fractures with the reference matrix (see 'reverse-50' in Fig. 4, a); (б) - map of stress tensors reconstructed for the example shown in Fig. 16, $a$, for each of the 26 local volumes in the study area.

1 - stress axes of compression (a) and extension (б): subhorizontal (arrow) and subvertical (circle) positions in space; 2-3 - cells with reconstructed stress tensors of compression in the NW-SE (2) and E-W (3) directions; 4 - cells in which, besides the compression setting, the strike-slip conditions were reconstructed (the corresponding stress tensor is shown outside the the site boundaries); 5 - axis of the large zone of deformation of the salt complex, which formed under sublatitudinal compression (arrow) and consists of three kinematically connected segments: north - right-lateral strike-slip, central - compression, south - left-lateral strike-slip.

вуаров приводит к миграции и локализации флюидов и, как следствие, к существенному увеличению электрической проводимости в пределах рассматриваемых зон.

Оси проводящих зон, выделенных для отдельных слоев в пределах северо-восточного полигона, за редкими исключениями сближены в пространстве (см. рис. 7, б). Это дает основание для их объ- единения и, таким образом, выделения нескольких разломных зон, нарушающих всю изученную толщу или ее существенные фрагменты. Справедливость подобного объединения подтверждается направленным смещением осей, соответствующих смежным горизонтам, которое в горизонтальной плоскости отражает наклонное положение одной и той же зоны. 
Анализ простираний флюидонасыщенных разломных зон, выделенных по материалам электроразведки (см. рис. 7, в), свидетельствует о доминировании на северо-восточном полигоне дизъюнктивов север-северо-западной и северо-восточной ориентировок. При парагенетическом анализе роза-диаграммы в качестве главной была принята вторая из перечисленных систем, которая преобладает по распространенности, а также использовалась в этом качестве во всех подобных построениях по Ковыктинскому ЛУ (см. рис. 11 ; рис. 15, $a$ ). В соответствии с полученными решениями наиболее вероятной обстановкой формирования сети разломных зон в нижней части осадочной толщи северо-восточного полигона была обстановка сдвига с субмеридиональной ориентацией оси сжатия и субширотной - оси растяжения. С меньшей достоверностью восстанавливается поле сжатия в направлении СЗ-ЮВ. Кроме того, привлечение к парагенетическому анализу информации об углах падения разломных зон, выделенных по данным электроразведки, свидетельствует о существовании в солевом комплексе обстановки северо-западюго-восточного растяжения, т.е. открытых фильтрующих трещин.

Таким образом, на существенно ином фактическом материале и для более глубоких горизонтов осадочной толщи Ковыктинского ЛУ подтверждается зонно-блоковый характер ее строения. Вместе с тем динамические обстановки формирования зонно-блоковой структуры (ЗБС) отличаются на разных глубинных уровнях. Обстановка растяжения в направлении СЗ-ЮВ фиксируется только в солевом (галогенно-карбонатном) комплексе, хотя поле сдвига с субмеридиональной ориентацией оси сжатия и субширотной ориентировкой оси растяжения сохраняется в обоих осадочных комплексах нижней части платформенного чехла. Здесь же дополнительно выделяется обстановка сжатия в направлении СЗ-ЮВ, которая ранее была зафиксирована по геолого-структурным данным во многих коренных выходах палеозойских пород за южной и восточной границей лицензионного участка. Кроме того, солевой комплекс несет отчетливые следы сжатия в широтном направлении, которые проявлены в виде дугообразной в плане структурной формы, состоящей из меридионального Большеириньского вала сжатия в центре, а также право- и левосдвиговых зон - на дистальных окончаниях.

\section{4. АНАЛИЗ РЕЗУЛЬТАТОВ ТЕКТОНОФИЗИЧЕСКИХ ИССЛЕДОВАНИЙ КОВЫКТИНСКОГО ЛУ}

В данном разделе, обобщающем результаты тектонофизического подхода к анализу разнотип- ной геолого-геофизической информации, вначале рассматривается специфика выявленной разными методами структуры платформенного чехла, затем этапность ее формирования в разнотипных динамических обстановках и некоторые практические следствия.

\section{1. ЗОННО-БЛОКОВАЯ СТРУКТУРА}

Полигоном для сопоставления структуры осадочной толщи, выделенной различными методами, является площадка треугольной формы в северовосточной части Ковыктинского ЛУ. Для нее предварительно была составлена схема зонно-блоковой структуры по данным линеаментного анализа рельефа (см. рис. 9, б). При этом, в отличие от аналогичных построений, осуществленных ранее для всего лицензионного участка (см. рис. 9, $a$ ), использовалась более детальная схема рельефа в изолиниях, созданная по его цифровой модели. Сопоставление рис. $9, a$, и рис. 9, б, свидетельствует, что схемы в целом подобны: вторая, как и ожидалось, детализирует первую. Однако ориентация и выраженность отдельных систем претерпели некоторые изменения в деталях (см. роза-диаграммы на врезках). Так, в границы полигона практически не попали меридиональные дизъюнктивные структуры, широко распространенные в верхах осадочной толщи на остальной части Ковыктинского ЛУ. Из северо-западных зон получили наибольшее распространение те, у которых простирание на $10-15^{\circ}$ ближе к северу. Таким образом, соответствующую систему дизъюнктивов правомерно считать северсеверо-западной, что еще более отчетливо выражено в проанализированных ранее геофизических полях (см. рис. 7, рис. 15).

Сопоставление схемы разломных зон, составленной для полигона по материалам линеаментного анализа рельефа (см. рис. 9, б), со схемами, полученными при тектонофизической интерпретации геофизических данных (рис. 7, б; рис. 15, б), показало, что, несмотря на отличие в глубинных уровнях и кардинально разные признаки выделения дизъюнктивных структур, они характеризуются вполне определенными чертами сходства. Совмещение составленных для каждой схемы роза-диаграмм (рис. $17, a$ ) свидетельствует о наличии в осадочной толще северо-восточного полигона пяти систем разломных зон. Север-северо-западная система 3 и северо-восточная система 5 имеют наибольшее распространение практически на всех схемах и, таким образом, составляют основу сети разломных зон всей осадочной толщи полигона. Разломные зоны широтной (система 1) и северо-западной (система 2) ориентировок, хотя и в существенно меньшем количестве, но также, согласно данным 
(б)

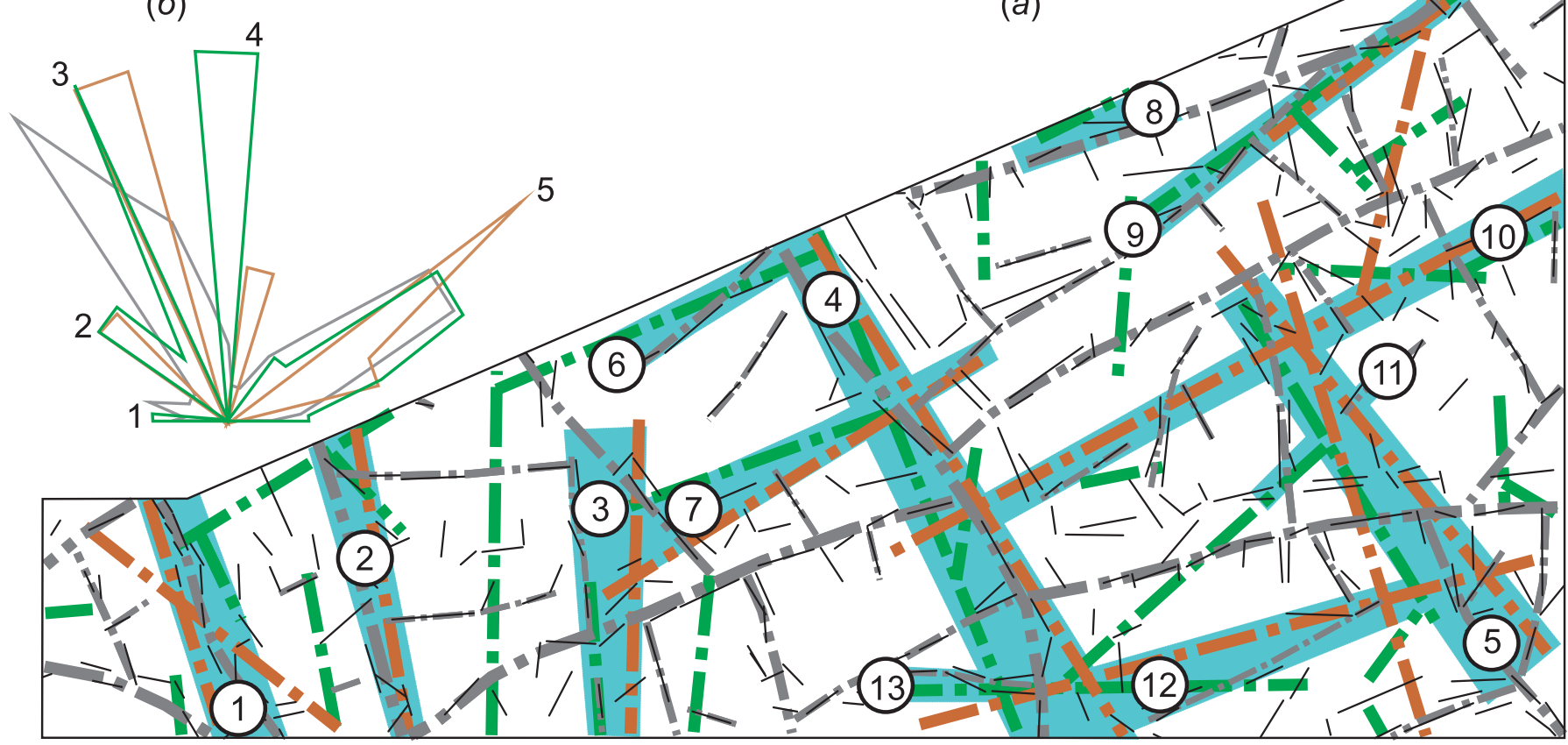

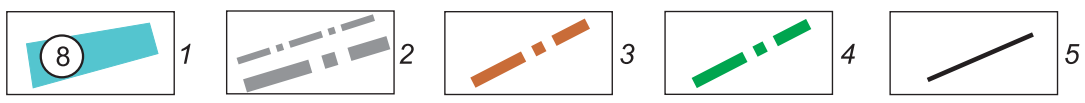

Рис. 17. Схема зонно-блоковой структуры платформенного чехла на северо-восточном участке детальных исследований $(a)$ и совмещенные роза-диаграммы простирания осей разломных зон (б), выделенных на основе анализа линеаментов рельефа (серый цвет), материалов электроразведки (коричневый цвет) и сейсморазведки (зеленый цвет).

1 - оси разломных зон (и их порядковые номера), выделяющихся более чем одним методом; 2 - оси разноранговых зон сгущения линеаментов рельефа; 3 - оси зон повышенной электропроводности; 4 - оси зон повышенной плотности разрывов, выделенных при анализе данных сейсморазведки; 5 - линеаменты рельефа.

Fig. 17. Scheme of the zone-block structure of the platform nappe in the NE segment of the detailed survey site $(a)$. Combined rose-diagrams of strike of the axes of the fault zones (б) identified from the relief lineaments (grey), electrical (brown) and seismic (green) survey data.

1 - axes of fault zones (and their numbers) detected by more than one method; 2 - axes of the zones with densely spaced lineaments of the relief (various ranks); 3 - axes of the zones of increased electrical conductivity; 4 - axes of the zones of increased density of fractures identified from seismic survey data; 5 - lineaments of the relief.

сейсморазведки и анализа элементов рельефа, нарушают все комплексы платформенного чехла. Разные части осадочной толщи в пределах северовосточного полигона отличаются по распространенности меридиональных дизъюнктивов (система 4), которые вследствие образования Большеириньского вала широко распространены в нижней части разреза и практически отсутствуют в верхней.

Единство сети разломных зон северо-восточного полигона подтверждается при сопоставлении положения осей главных структур, которые выделяются более чем одним методом (см. рис. 7, б; 9, б; 15, б). Из рис. $17, a$, где сближенные в пространстве оси объединены в закрашенные полосы, видно, что практически все они, хотя и по разным признакам, проявлены в обеих частях осадочной толщи. Ис- ключение составляют две зоны северо-восточной ориентировки (7 и 10), выделенные по геофизическим данным только для солевого и подсолевого комплексов, которым, судя по сети более мелких дизъюнктивов, свойственны определенные особенности в дислоцированности пород. Таким образом, сеть наиболее крупных дизъюнктивов в пределах северо-восточного полигона является единой для всей осадочной толщи. Более того, представленная на рис. $17, a$, схема в первом приближении отражает зонно-блоковую структуру, выводы о существовании которой на Ковыктинском ЛУ были сделаны ранее при анализе каждой группы геологических и геофизических материалов.

Итак, платформенный чехол Ковыктинского ЛУ представляет систему сравнительно массивных 
блоков, контактирующих по зонам с более высокой дислоцированностью пород. С позиций тектонофизики они являются разломными, несмотря на то, что в большинстве случаев не содержат магистрального сместителя. Эти разломы находятся в осадочном чехле на ранней стадии развития вследствие слабой интенсивности деформационного процесса на платформенной территории. Данный фактор также является причиной отсутствия замкнутости сети разломных зон Ковыктинского ЛУ (см. рис. 9; рис. $17, a$ ) в отличие от тектонически активных областей, где блоки обычно полностью ограничены разрывными структурами по периметру [Sherman et al., 1999; Gatinsky, Rundquist, 2004; Seminskii, 2008]. Подобный характер делимости был ранее установлен для осадочного чехла на ряде нефтяных месторождений Западной Сибири [Glukhmanchuk, Vasilevskiy, 2013], однако в качестве активных сегментов дизъюнктивной сети выступали лишь отдельные участки зон трещиноватости. Замкнутость разрывной сети, наряду с вложением мелких блоков в более крупные, свидетельствует о существовании строгой иерархической соподчиненности элементов ЗБС. Ее установление для богатой углеводородами платформенной территории может быть темой отдельного целенаправленного исследования, так как данный вопрос напрямую связан с оконтуриванием перспективных площадей и объемов природных трещинных резервуаров в чехле.

Основу ЗБС Ковыктинского ЛУ составляют зоны северо-восточного простирания, а также дизъюнктивы генерализованной северо-западной ориентировки, которая на отдельных площадях (например, северо-восточном полигоне) меняется до западсеверо-западной (см. рис. 9). Далее по распространенности следуют разломные зоны субмеридиональной, а затем субширотной ориентировки. Существенным элементом зонно-блоковой структуры являются субгоризонтальные зоны, без которых подвижность блоков (лишь за счет перемещений по субвертикальным и наклонным зонам) реализовываться не может. Субгоризонтальные зоны могут представлять фрагменты наиболее пластичных слоев осадочной толщи и/или участки повышенной трещиноватости (трещинные межсолевые коллекторы) на границах слоев - концентраторов напряжений.

Наличие вещественной и структурно-механической расслоенности платформенного чехла в пределах Ковыктинского ЛУ является причиной определенных различий в зонно-блоковой структуре, характерной для его отдельных комплексов. В этом отношении выделяется верхняя часть разреза по отношению к солевому и подсолевому комплексам. При этом, если судить по детально изученному северо-восточному полигону, деформации галогенно-карбонатной толщи проявлены более интенсивно по отношению к самой нижней части разреза. Существование различий связано с особенностями напряженного состояния и механизмами деформаций, проявившимися на разных этапах структурообразования, что рассматривается ниже при обобщении всех полученных материалов.

\section{2. ДИНАМИЧЕСКИЕ ОБСТАНОВКИ И ЭТАПЫ СТРУКТУРООБРАЗОВАНИЯ}

Для реконструкций региональных полей напряжений на Ковыктинском ЛУ в качестве исходных материалов использовались данные о разрывных структурах, выявленных разными методами и в различных комплексах осадочной толщи. Обобщение полученных результатов позволило выделить четыре главных динамических обстановки, под воздействием которых сформировалась зонно-блоковая структура Ковыктинского ГКМ (рис. 18): I растяжение в направлении СЗ-ЮВ, II - сдвиг с ориентировкой субгоризонтальной оси сжатия в субмеридиональном и оси растяжения в широтном направлении, III - сжатие в направлении C3-ЮB, IV - сжатие в направлении B-3.

Наиболее отчетливо в разрезе осадочной толщи Ковыктинского ЛУ проявлено поле сдвига II (рис. 18, б); оно надежно восстановлено для верхней части разреза по сети линеаментных зон (см. рис. 12 , a), а для нижележащих комплексов - по парагенезисам разломных зон, отличающихся высокой электрической проводимостью (см. рис. 7, в). Поле сжатия III также характерно для всего платформенного чехла (рис. 18), но если в низах разреза оно отчетливо фиксируется по материалам электро- и сейсморазведки (см. рис. 7, в; рис. 16, б), то для его верхней части соответствующие стресстензоры были реконструированы по геологоструктурным данным лишь за границами лицензионного участка (см. рис. 13). Две оставшихся динамических обстановки характерны только для отдельных частей осадочной толщи (рис. 18). Растяжение I выявлено в солевом комплексе по материалам электроразведки с учетом углов падения зон высокой электропроводности, а также по данным линеаментного анализа рельефа в верхней части разреза (см. рис. 12, б). Сжатие IV было установлено только в солевом комплексе по данным сейсморазведки (см. рис. 16, б). Таким образом, каждый из трех осадочных комплексов характеризуется собственным набором динамических обстановок, который определяет единство структуры осадочной толщи в целом и ее специфику в отдельных частях разреза. 


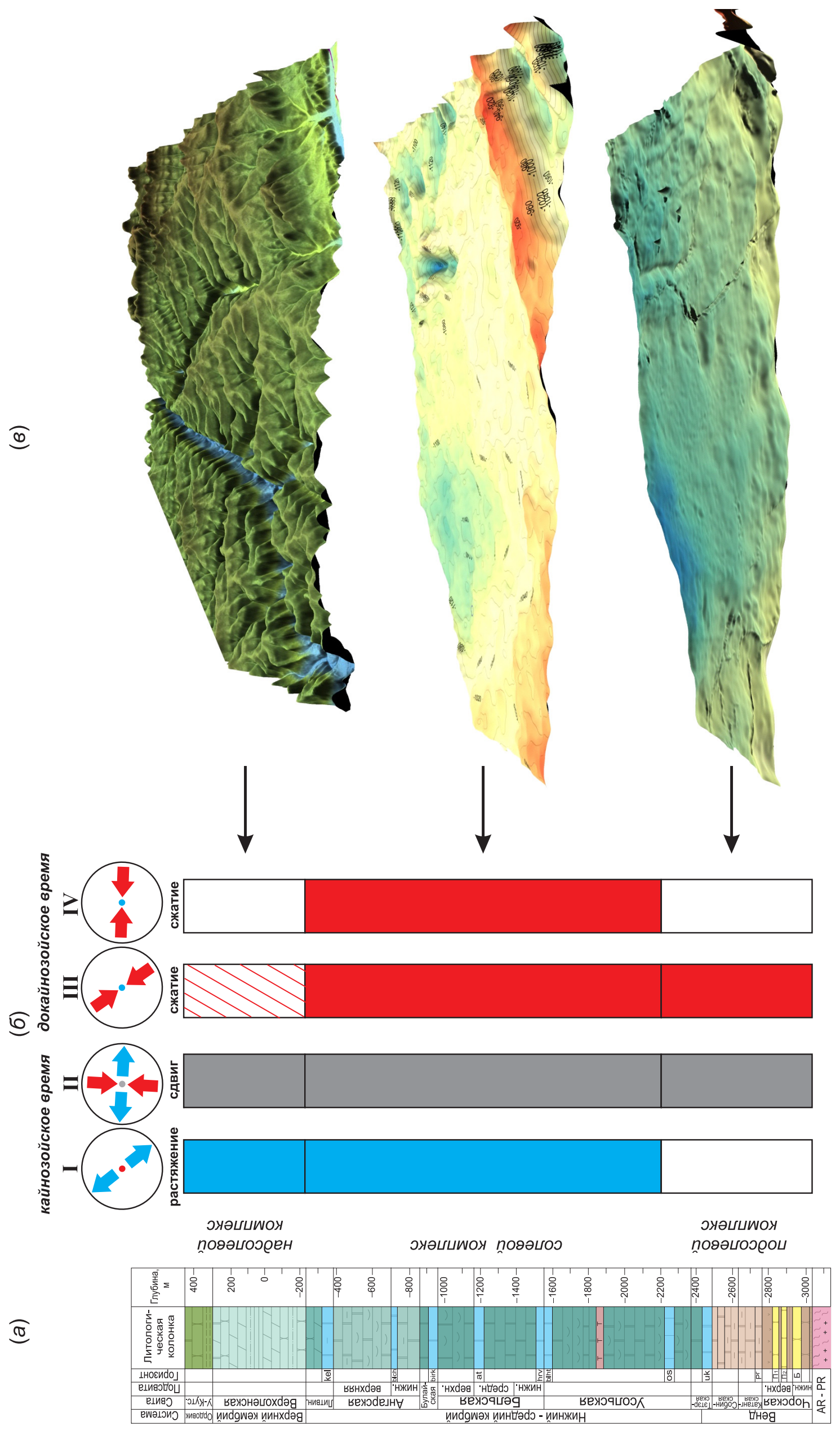




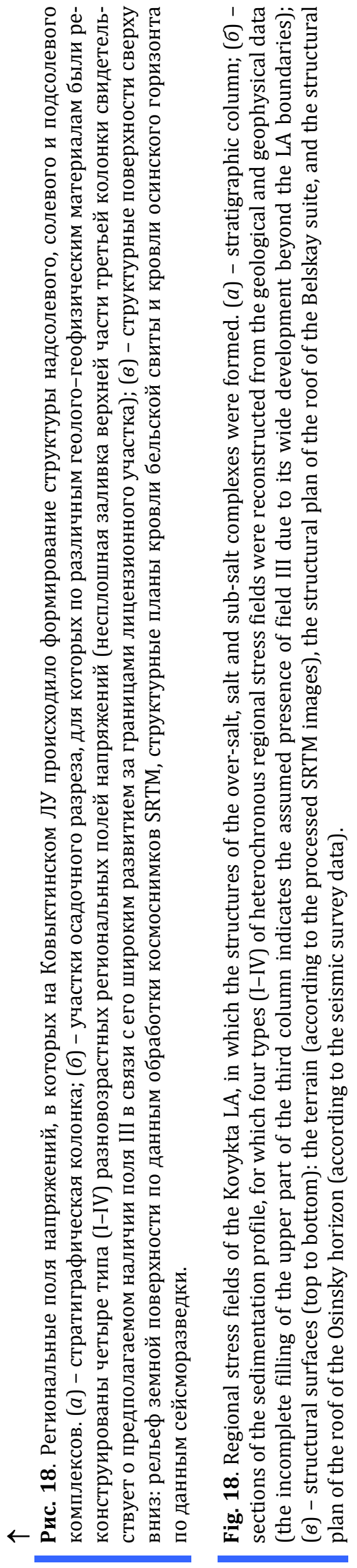

Характер выделенных полей в совокупности с представленными в статье геолого-структурными оценками возраста позволяет обосновать временную привязку выявленных динамических обстановок, т.е. определить этапность формирования структуры платформенного чехла на Ковыктинской площади. Выявленным полям напряжений необходимо, прежде всего, поставить в соответствие три крупных этапа тектонического развития земной коры, интенсивно выраженные в смежном Байкало-Становом подвижном поясе. Под действием растяжения в направлении СЗ-ЮВ (поле I) в позднем кайнозое и до настоящего времени происходит раскрытие Байкальского рифта [Delvaux et al., 1997; San'kov et al., 1997]. В условиях сдвига с ориентацией оси сжатия в меридиональном и оси растяжения в широтном направлении (поле II) протекала в раннем кайнозое раннеорогенная стадия развития горно-складчатого пояса [Delvaux et al., 1997; San'kov et al., 1997; Mats et al., 2001]. Анализ рельефа, сейсмологических и геолого-структурных данных свидетельствует, что деформации этих этапов затронули на Ковыктинском ЛУ практически все слои осадочной толщи, проявившись наиболее интенсивно в ее верхней части, в надосинской толще палеозоя.

Известный для Прибайкалья этап палеозойского сжатия земной коры [Zamaraev et al., 1976; Sizykh, 2001] отразился на Ковыктинской площади в полях соответствующего типа с ориентировкой активной оси в направлении СЗ-ЮВ (поле III) и 3-В (поле IV). Различие в ориентировке сжатия связано с тем, что на изученной территории происходило наложение двух динамических обстановок. Первая из них обусловлена собственно байкальским тектогенезом, а вторая определялась давлением с востока, где располагался субмеридиональный фронт складчато-надвиговых структур Патомской дуги. Подобная интерпретация структурной картины наиболее вероятна, однако существуют признаки, свидетельствующие об активизации по крайней мере одной из этих обстановок в более поздние периоды развития изучаемого региона. Такой обстановкой является субширотное сжатие (рис. 18, б), послужившее причиной формирования в пластичной толще солей и гипсов характерной структуры течения (см. рис. 15,6 , рис. 16, б). Ее активизация могла иметь место в позднем кайнозое вследствие гравитационного скольжения масс по солевым горизонтам с востока на запад от асимметричного локального поднятия вершинной поверхности, связанного с подъемом плеча плиоценчетвертичной Хандинской впадины (коричневое поле на рис. 13).

Итак, тектоническое строение Ковыктинского лУ определяется наличием сети разломных зон, 
сформировавшейся как минимум в четырех динамических обстановках, которые по-разному воздействовали на отдельные комплексы осадочного чехла. Наиболее сложнодислоцированной является средняя часть разреза, испытавшая, кроме тектонического, гравитационное воздействие вследствие высокой податливости галогенно-карбонатной толщи в отношении пластических деформаций. Таким образом, данная часть разреза является наиболее проблемной в плане фрагментации пластов-коллекторов, кольматации трещиноватости и проявлений АВПД флюидных систем, существенно снижающих эффективность проходки скважин на Ковыктинском ГКМ.

\section{3. НЕКОТОРЫЕ СЛЕДСТВИЯ ТЕКТОНОФИЗИЧЕСКОГО ПОДХОДА К АНАЛИЗУ РАЗНОТИПНЫХ МАТЕРИАЛОВ ДЛЯ СЕВЕРО- ВОСТОЧНОЙ ЧАСТИ КОВЫКТИНСКОГО ЛУ}

Тектонофизический анализ, кроме общих закономерностей строения и этапности формирования структуры платформенного чехла, позволяет получить определенные результаты прикладной направленности. Ниже они представлены на примере северо-восточного полигона, который был наиболее полно изучен комплексом геолого-геофизических методов. Прежде всего, для этой площади выявлена зонно-блоковая структура, главные элементы которой - разломные зоны - за редким исключением (зоны 7 и 10) в том или ином виде проявляются на всех уровнях осадочного чехла (см. рис. $17, a)$. Важным в плане разведки и эксплуатации Ковыктинского ГКМ является прогноз степени дислоцированности осадочного чехла, которая в пределах разломных зон зависит от динамической обстановки их формирования и при прочих равных условиях больше у дизъюнктивов, формирующихся при сжатии, чем при сдвиге и, тем более, при растяжении [Sherman et al., 1983; Seminsky, 2003]. Для северо-восточного полигона анализ проводился с учетом установленной ранее этапности развития зонно-блоковой структуры.

Тринадцать выделенных разломных зон в первом приближении образуют диагональную сеть, у которой каждая из систем представлена примерно одинаковым количеством дизъюнктивов (см. рис. $17, a)$. Разброс ориентировок дизъюнктивов северо-западной системы достаточно широк, что позволяет отнести к ней и субмеридиональную зону 3. Субширотное направление представлено на данной площади только одной небольшой зоной 13 и поэтому не может рассматриваться в качестве самостоятельной системы. Для разломных зон каждой из двух главных систем в таблице показана история подвижек в соответствии с их ролью в парагенезисе разрывов 2-го порядка, активных в

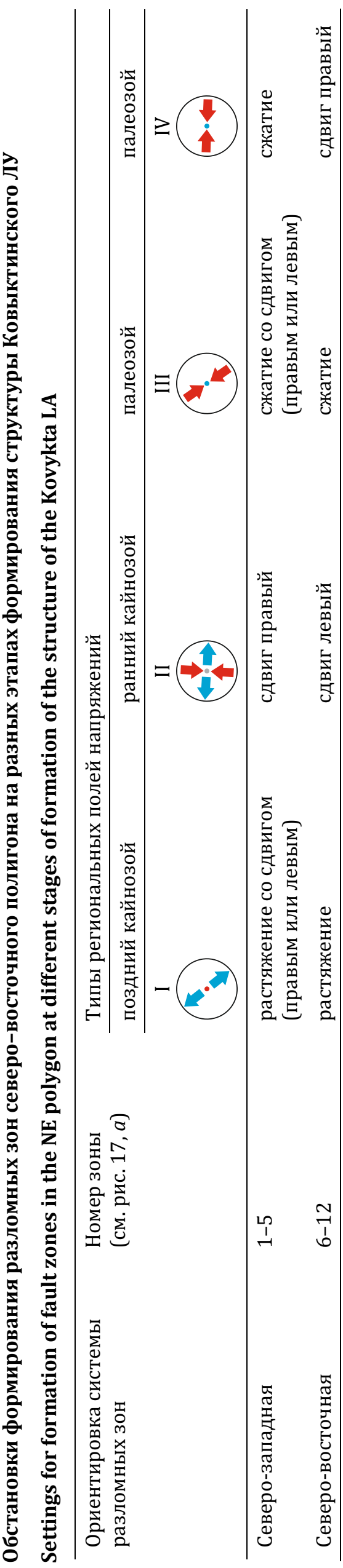


каждом из четырех полей напряжений 1-го порядка, выявленных для участка исследований.

Внутренняя структура разломных зон северовосточного простирания формировалась в условиях правого сдвига и сжатия в палеозое, а затем была активизирована в кайнозое сначала в режиме левого сдвига, а затем растяжения. Северо-западные дизъюнктивы закладывались в палеозойское время при сжатии и сжатии со сдвигом, в раннем кайнозое были правыми сдвигами, а в позднем кайнозое развивались в условиях растяжения со сдвигом. Смешанные динамические обстановки в последнем случае определяются принадлежностью северо-западных разломов к системе поперечных нарушений, которые при отклонении от линии тектонического транспорта в одну или другую сторону приобретают, кроме раздвиговой, право- или левосдвиговую составляющую перемещений [Seminsky, 2003].

Полученные данные позволяют провести относительную оценку степени дислоцированности пород платформенного чехла в пределах северовосточного полигона. Наименее нарушены разрывами пространства блоков (см. рис. 17, б). Наиболее дислоцированными являются узлы пересечения разломных зон друг с другом или с субгоризонтальными прослоями солей, способствующих срыву и перемещению отдельных фрагментов осадочной толщи. Из дизъюнктивных структур более высокой степенью дислоцированности отличаются породы в зонах динамического влияния северозападных разломов, так как в разные тектонические эпохи они развивались главным образом при сжатии и сдвиге с минимальным вкладом растяжения (таблица). Вдоль простирания одной зоны породный массив нарушен неравномерно: выделяются сегменты с высокой интенсивностью напряженного состояния (см. рис. 8, б) и повышенной плотностью вторичных разрывов (см. рис. 15 , б), в пределах которых наиболее вероятны существенные вариации пластовых давлений флюидов, рапо- и рапогазопроявления и пр.

Представленная оценка отражает общий подход к выделению проблемных участков на газоконденсатном месторождении со сложной структурой и соответствует масштабу проведенных исследований на северо-восточном полигоне. Для решения производственных задач, связанных с ключевой проблемой выбора площадок строительства разведочных и эксплуатационных скважин, необходимо проведение тектонофизических исследований в укрупненном масштабе с выделением подэтапов тектонического развития территории и построением объемной схемы зонно-блоковой структуры с максимально возможной степенью детальности. Особую значимость при этом представляет выде- ление активных сегментов ЗБС, а также оценка степени влияния на свойства пород (в т.ч. резервуаров и покрышек) современного напряженного состояния в зоне Байкальского рифта.

\section{5. ЗАКЛЮЧЕНИЕ}

Применение современных приемов и способов тектонофизического анализа разнотипной геолого-геофизической информации позволило установить главные закономерности разломного строения и напряженного состояния платформенного чехла на Ковыктинском газоконденсатном месторождении (ГКМ), которые состоят в следующем.

1. Дизъюнктивная структура Ковыктинского ЛУ является зонно-блоковой (ЗБС), т.е. представляет иерархию блоков, которые контактируют друг с другом по широким зонам сгущения сравнительно непротяженных разрывов. Это разломные зоны, внутренняя структура которых в платформенном чехле находится на ранней стадии развития и не содержит сместителей магистрального типа. Их существование в совокупности с реологической расслоенностью определяет неоднородность осадочной толщи в плане напряженного состояния, степени нарушенности и проницаемости для флюидов и газа.

2. Современная сеть разломных зон на участке исследований формировалась в четырех региональных динамических обстановках (I-IV), которые согласуются с главными этапами тектонического развития смежного Байкало-Станового подвижного пояса. Позднекайнозойский рифтовый этап его формирования отразился на Ковыктинской площади в виде растяжения пород осадочного чехла в направлении СЗ-ЮВ (поле I). Раннекайнозойский орогенный этап обусловил проявление обстановки сдвига с меридиональной ориентацией оси сжатия и широтной - оси растяжения (поле II). Давление на платформу со стороны разноориентированных сегментов подвижного пояса в палеозое отразилось на изучаемой территории в виде обстановок сжатия в направлении ЮВ-С3 (поле III) и В-3 (поле IV). Поля III и IV могли быть реактивированы в кайнозое под влиянием гравитационных процессов, связанных с локальными поднятиями рельефа в окрестностях Ковыктинского ЛУ.

3. Отдельным этапам тектогенеза соответствует определенная зонно-блоковая структура, которая состоит из активных разломных зон и их сегментов, отличающихся степенью неоднородности внутреннего строения, кинематикой и интенсивностью подвижек. Стиль современной ЗБС на Ковыктинской площади определяется доминированием субвертикальных разломных зон северо-за- 
падной (местами север-северо-западной) и северовосточной ориентировки в сочетании с зонами субгоризонтальных послойных срывов, обеспечивающих подвижность контактирующих блоков. Некоторые из крупных зон нарушают всю осадочную толщу, однако сеть мелких разрывов достаточно специфична для ее отдельных частей, т.е. надсолевого, солевого и подсолевого комплексов. Наиболее сложной является структура среднего комплекса, который вследствие высокой податливости солевых прослоев активно откликался на воздействия тектонической и гравитационной природы.

В методическом отношении зонно-блоковая модель строения осадочного чехла, выявленная на примере Ковыктинского ЛУ, представляет основу для комплексного подхода к исследованию ГКМ, располагающихся в реологически-расслоенной среде регионов, которые характеризуются слабой, но отчетливо проявленной тектонической активностью. Основными составляющими такого подхода являются дистанционные и геолого-структурные способы исследования верхних горизонтов платформенного чехла, а также геофизические (сейсмо-, электро-, гравиразведка и др.) методы зондирования его более глубоких частей в сочетании с бурением и каротажем скважин. Каждый из методов обладает разными возможностями в плане выявления разломных зон ранних стадий развития, од- нако применение единого тектонофизического подхода к анализу их результатов позволяет осуществить картирование зонно-блоковой структуры для всей толщи платформенного чехла.

ЗБС конкретного месторождения послужит основой для его районирования в отношении проявлений углеводородов, прогноза АВПД пластов, степени нарушенности и типов напряженно-деформированного состояния пород. Решение этой задачи позволит получить дополнительное (к уже имеющимся на производстве) обоснование для выбора мест бурения скважин, которые могут быть пройдены без осложнений и с перспективой обнаружения скоплений газонасыщенных пластов-коллекторов.

\section{6. БЛАГОДАРНОСТИ}

Авторы благодарны директору ИЗК СО РАН, чл.-корр. РАН Д.П. Гладкочубу, генеральному директору АО «Иркутское электроразведочное предприятие», к.т.н. Ю.А. Агафонову, главному геологу 000 «Газпром геологоразведка» С.Г. Крекнину за всестороннюю поддержку исследований на всех этапах его реализации, а также А.С. Черемных, А.В. Парфеевец, Н.В. Мисюркеевой, И.А. Шелохову и Л.М. Бызову за помощь в сборе и обработке фактического материала.

\section{7. ЛИТЕРАTУРA / REFERENCES}

Aarre V., Astratti D., Dayyni T.N., Mahmoud S.L., Clark A., Stellas M., Stringer J., Toelle B., Vejbaek O., White G., 2012. Seismic detection of subtle faults and fractures. Oilfield Review 24 (2), 28-43.

Bahorich M., Farmer S., 1995. 3-D seismic discontinuity for faults and stratigraphic features: the coherence cube. The Leading Edge 14 (10), 1053-1058. https://doi.org/10.1190/1.1887523.

Brutton T., Cahn D.V., Duc N.V., Gillespie P., Hunt D., Li B., Marcinew R., Ray S., Montaron B., Nelson R., Shroderbek D., Sonneland $L$., 2006. The nature of naturally fractured reservoirs. Oilfield Review 18 (2), 4-23.

Buddo I.V., Baryshev L.A., Agafonov Y.A., Sharlov M.V., Pospeev A.V., 2013. Joint interpretation of seismic and TEM data from the Kovykta gas-condensate field, East Siberia. In: 75th EAGE Conference \& Exhibition incorporating SPE EUROPEC. London. https://doi.org/10.3997/2214-4609.20130275.

Buddo I.V., Baryshev L.A., Pospeev A.V., Murzina E.V., Agafonov Y.A., 2012. Experience of seismic (CDP) and electromagnetic (TEM) joint data interpretation on the example of Kovykta gas condensate field. In: Geobaikal 2012 - 2nd EAGE International Research and Application Conference on Electromagnetic Research Methods and Integrated Geophysical Data Interpretation. Irkutsk (in Russian] [Буддо И.В., Барышев Л.А, Поспеев А.В., Мурзина Е.В., Агафонов Ю.А. Опыт комплексирования МОГТ и электроразведки (ЗСБ) на примере Ковыктинского ГКМ // Вторая международная научно-практическая конференция по электромагнитным методам исследования «Геобайкал-2012»: Тезисы докладов. Иркутск, 2012]. https://doi.org/10.3997/2214-4609.20143511.

Buddo I.V., Misurkeeva N.V., Agafonov Y.A., Smirnov A.S., 2016. Optimal sequence of gas field investigations from the Kovycta gas-condensate field. In: 7th Saint Petersburg International Conference \& Exhibition. https://doi.org/ 10.3997/2214-4609.201600167.

Buddo I.V., Pospeev A.V., Agafonov Yu.A., 2011. Some aspects of detecting reservoirs in the sedimentary cover of the southern areas of the Siberian platform based on the non-stationary electromagnetic sounding data. In: Proceedings of the All-Russia M.N. Berdichevsky and L.L. Vanyan School-Seminar on Electromagnetic Sounding of the Earth. Book 2. St. Petersburg, p. 170-173 (in Russian) [Буддо И.В., Поспеев А.В., Агафонов Ю.А. Некоторые аспекты выделения пластов-коллекторов в осадочном чехле юга Сибирской платформы по данным нестационарных электромагнитных зондирований // Материалы всероссийской школы-семинара имени М.Н. Бердичевского и Л.Л. Ваньяна по электромагнитным зондированиям Земли. СПб., 2011. Кн. 2. С. 170-173]. 
Canh D.V., Que N.V., Duc N.V., Gillespie P., Hunt D., Li B., Marcinew R., Ray S., Montaron B., Nelson R., Schoderbek D., Sonneland $L ., 2006$. The nature of naturally fractured reservoirs. Oilfield Review 18 (2), 4-23.

Chopra S., Marfurt K.J., 2005. Seismic attributes - A historical perspective. Geophysics 70 (5), 3SO-28SO. https:// doi.org/10.1190/1.2098670.

Chopra S., Marfurt K.J., Mai H.T., 2009. Using automatically generated 3D rose diagrams for correlation of seismic fracture lineaments with similar lineaments from attributes and well log data. First Break 27 (10), 37-42. https:// doi.org/10.3997/1365-2397.2009016.

Delvaux D., 1993. The TENSOR program for reconstruction: examples from East African and the Baikal rift systems. Terra Abstracts (Abstr. suppl. Terra Nova) 5 (1), 216.

Delvaux D., Moyes R., Stapel G., Petit C., Levi K., Miroshnitchenko A., Ruzhich V., Sankov V., 1997. Paleostress reconstruction and geodynamics of the Baikal region, Central Asia. Part II: Cenozoic rifting. Tectonophysics 282 (1-4), 1-38. https://doi.org/10.1016/S0040-1951(97)00210-2.

Dubrovin M.A., 1979. Salt Tectonics of the Upper Lena Basin in the Siberian platform. Nauka, Siberian Branch, Novosibirsk, 94 p. (in Russian) [Дубровин М.A. Соляная тектоника Верхне-Ленской впадины Сибирской платформы. Новосибирск: Наука. С0, 1979. 94 с.].

Freund R., 1974. Kinematics of transform and transcurrent faults. Tectonophysics 21 (1-2), 93-134. https://doi.org/ 10.1016/0040-1951(74)90064-X.

Friedman M., Handin J., Logan J.M., Min K.D., Stearns D.W., 1976. Experimental folding of rocks under confining pressure: Part III. Faulted drape folds in multilithologic layered specimens. Geological Society of America Bulletin 87 (7), 1049-1066. https://doi.org/10.1130/0016-7606(1976)87<1049:EFORUC>2.0.C0;2.

Gatinsky Y.G., Rundquist D.V., 2004. Geodynamics of Eurasia: plate tectonics and block tectonics. Geotectonics 38 (1), 1-16.

Glukhmanchuk E.D., Krupitskii V.V., Leontievskii A.V., 2016. The reason for discrepancy between deposit geological model and deposit production results. Geologiya Nefti i Gaza (Oil and Gas Geology) (1), 45-51 (in Russian) [Глухманчук Е.Д., Крупицкий В.В., Леонтьевский А.В. Причина несоответствия геологических моделей месторождений результатам их разработки // Геология нефти и газа. 2016. № 1. С. 45-51].

Glukhmanchuk E.D., Vasilevskiy A.N., 1998. Method of detailed analysis of the deformation field structure from seismic data and some results of its application in the fields of West Siberia. In: Geophysical methods of studying the Earth's crust. SB RAS Publishing House, Novosibirsk, p. 131-140 (in Russian) [Глухманчук Е.Д., Василевский А.Н. Методика детального анализа структуры поля деформаций по данным сейсморазведки и некоторые результаты ее применения на месторождениях Западной Сибири // Геофизические методы изучения земной коры. Новосибирск: Изд-во СО РАН, 1998. С. 131-140].

Glukhmanchuk E.D., Vasilevskiy A.N., 2013. Description of fracture zones based on the structural inhomogeneity of the reflector deformation field. Russian Geology and Geophysics 54 (1), 82-86. https://doi.org/10.1016/j.rgg.2012. 12.007.

Gogonenkov G.N., Timurziev A.I., 2010. Strike-slip faults in the West Siberian basin: implications for petroleum exploration and development. Russian Geology and Geophysics 51 (3), 304-316. https://doi.org/10.1016/j.rgg.2010.02. 007.

Gorlov I.V., Smirnov A.S., Ignatiev S.F., Vakhromeev A.R., Pospeev A.V., Misyurkeeva N.V., Agafonov Yu.A., Buddo I.V., 2016. New potential gas object in the Cambrian deposits of the Kovykta gas condensate field. In: GeoBaikal-2016. Irkutsk (in Russian) [Горлов И.В., Смирнов А.С., Игнатьев С.Ф., Вахромеев А.Г., Поспеев А.В., Мисюркеева Н.В., Агафонов Ю.А., Буддо И.В. Новые газоперспективные объекты в кембрийских отложениях Ковыктинского ГКМ // GeoBaikal-2016. Иркутск, 2016]. https://doi.org/10.3997/2214-4609.201601706.

Guiraud M., Laborde O., Philip H., 1989. Characterisation of various types of deformation and their corresponding deviatoric stress tensor using microfault analysis. Tectonophysics 170 (3-4), 289-316. https://doi.org/10.1016/00401951(89)90277-1.

Hancock P.L., 1985. Brittle microtectonics: principles and practice. Journal of Structural Geology 7 (3-4), 437-457. https://doi.org/10.1016/0191-8141(85)90048-3.

Harding T.P., 1974. Petroleum traps associated with wrench faults. AAPG Bulletin 58 (7), 1290-1304.

Harding T., Lowell J.D., 1979. Structural styles, their plate-tectonic habitats, and hydrocarbon traps in petroleum provinces. AAPG Bulletin 63 (7), 1016-1058.

Heidbach O., Tingay M., Barth A., Reinecker J., Kurfeß D., Müller B., 2010. Global crustal stress pattern based on the World Stress Map database release 2008. Tectonophysics 482 (1-4), 3-15. https://doi.org/10.1016/j.tecto.2009. 07.023.

Il'in A.I., Vakhromeev A.G., Misyurkeeva N.V., Buddo I.V., Agafonov Yu.A., Pospeev A.V., Smirnov A.S., Gorlov I.V., 2016. New approach to the prediction of anomalously high formation pressure in the carbonate rapa-bearing Cambrian reservoirs at the Kovykta LA. In: GeoBaikal-2016. Irkutsk (in Russian) [Ильин А.И., Вахромеев А.Г., Мисюркеева Н.В., Буддо И.В., Агафонов Ю.А., Поспеев А.В., Смирнов А.С., Горлов И.В. Новый подход к прогнозу АВПД в карбонатных рапоносных коллекторах кембрия на Ковыктинском ГКМ // GeoBaikal-2016. Иркутск, 2016]. https://doi.org/10.3997/2214-4609.201601692.

Khromova I.Yu., 2008. Migration of duplex waves - the method for mapping fractured zones of tectonic genesis Geologiya Nefti i Gaza (Oil and Gas Geology) (3), 37-47 (in Russian) [Хромова И.Ю. Миграция дуплексных волн - 
метод картирования трещиноватых зон тектонического генезиса // Геология нефти и газа. 2008 . № 3. C. 37-47].

Kim Y.S., Peacock D.C., Sanderson D.J., 2004. Fault damage zones. Journal of Structural Geology 26 (3), 503-517. https:// doi.org/10.1016/j.jsg.2003.08.002.

Levi K.G., Kulchitsky A.A., 1981. Planation surface in the northeastern Baikal rift zone. In: Relief and Quaternary deposits of the Stanovoy upland. Nauka, Moscow, p. 19-35 (in Russian) [Леви К.Г., Кульчицкий А.А. Поверхности выравнивания северо-восточной части Байкальской рифтовой зоны // Рельеф и четвертичные отложения Станового нагорья. М.: Наука, 1981. С. 19-35].

Logachev N.A. (Ed.), 1984. Map of Neotectonics of Pribaikalie and Transbaikalia. Scale 1:2500000. IEC SB RAS, Irkutsk (in Russian) [Карта неотектоники Прибайкалья и Забайкалья. Масштаб 1:2500000 / Ред. Н.А. Логачев. Иркутск: ИЗК СО РАН, 1984]

Malykh A.V., 1985. Fields of tectonic stresses in the folds of the Nepa and Sosninskaya fold zones in the southern Siberian platform. Geologiya i Geofizika (Soviet Geology and Geophysics) 26 (6), 31-37 (in Russian) [Малых А.В. Поля тектонических напряжений в складках Непской и Соснинской зон складчатости юга Сибирской платформы // Геология и геофизика. 1985. Т. 26. № 6. С. 31-37].

Mandl G., 1988. Mechanics of Tectonic Faulting: Models and Basic Concepts. Elsevier, Amsterdam, 407 c.

Mats V.D., Ufimtsev G.F., Mandelbaum M.M., Alakshin A.M., Pospeev A.V., Shimaraev M.N., Khlystov O.M., 2001. Cenozoic of the Baikal Rift Basin: Structure and Geological History. Geo Branch, SB RAS Publishing House, Novosibirsk, $252 \mathrm{p}$. (in Russian) [Мац В.Д., Уфимцев Г.Ф., Мандельбаум М.М., Алакшин А.М., Поспеев А.В., Шимараев М.Н., Хлыстов O.M. Кайнозой Байкальской рифтовой впадины: строение и геологическая история. Новосибирск: Изд-во СО РАН, филиал «Гео», 2001. 252 с.].

Melnikova V.I., Radziminovich N.A., 1998. Mechanisms of action of earthquake foci in the Baikal region over the period 1991-1996. Geologiya i Geofizika (Russian Geology and Geophysics) 39 (11), 1598-1607.

Mendry Ya.V., 2013. Attribute analysis of seismic data for mapping zones of fracturing. Zbirnik Naukovikh Pratz Ukr. DGRI (4), 42-51 (in Russian) [Мендрий Я.В. Атрибутный анализ сейсмических данных при картировании зон трещиноватости // Збірник наукових праць Укр. ДГРІ. 2013. № 4. С. 42-51].

Mendry Ya.V., Tyapkin Yu.K., 2012. Development of coherence calculation technology based on improved seismic recording models. Geophysical Journal 34 (3), 102-115 (in Russian) [Мендрий Я.В., Тяпкин Ю.К. Развитие технологии расчета когерентности на основе усовершенствованных моделей сейсмической записи // Геофизический журнал. 2012. Т. 34. № 3. С. 102-115].

Misyurkeeva N.V., Pospeev A.V., Vakhromeev A.G., Gorlov I.V., Smirnov A.S., Ignatiev S.F., Agafonov Yu.A., Buddo I.V., 2016. On evaluating the potential of the Bokhan horizon in the Kovykta gas condensate field. In: GeoBaikal-2016. Irkutsk (in Russian) [Мисюркеева Н.В., Поспеев А.В., Вахромеев А.Г., Горлов И.В., Смирнов А.С., Игнатьев С.Ф., Агафонов Ю.А., Буддо И.В. К вопросу об оценке потенциала боханского горизонта венда на Ковыктинском газоконденсатном месторождении // GeoBaikal-2016. Иркутск, 2016]. https://doi.org/10.3997/2214-4609.201601 712.

Mogilev B.A., 1978. Geological Map of the USSR. Scale 1:200000. Angara-Lena series. Sheet N-48-KhP. Explanatory Note. Moscow, 82 p. (in Russian] [Могилев Б.А. Геологическая карта СССР масштаба 1:200000. Серия АнгароЛенская. Лист N-48-ХП. Объяснительная записка. М., 1978. 82 с.].

Mushin I.A., Korol'kov Yu.S., Chernov A.A., 2001. Identification and Mapping of Disjunctive Dislocations by Methods of Prospecting Geophysics. Nauchny Mir, Moscow, 120 p. (in Russian) [Мушин И.А., Корольков Ю.С., Чернов А.А. Выявление и картирование дизъюнктивных дислокаций методами разведочной геофизики. М.: Научный мир, 2001. 120 с.].

Naylor M.A., Mandl G.T., Supesteijn C.H.K., 1986. Fault geometries in basement-induced wrench faulting under different initial stress states. Journal of Structural Geology 8 (7), 737-752. https://doi.org/10.1016/0191-8141(86) 90022-2.

Nezhdanov A.A., Ogibenin V.V., Gorsky O.M., Mitrofanov A.D., Korobeinikov A.A., Tryasin E.Yu., 2012. Determination of the natural fracturing of oil and gas condensate fields of the Yamal-Nenets Autonomous District on the basis of processing and interpretation of remote sensing data. Vesti Gazovoy Nauki (News of Gas Science) (1), 167-181 (in Russian) [Нежданов А.А., Огибенин В.В., Горский О.М., Митрофанов А.Д., Коробейников А.А., Трясин Е.Ю. Определение природной трещиноватости нефтегазоконденсатных месторождений ЯНАО на основе обработки и интерпретации данных дистанционных методов // Вести газовой науки. 2012. № 1. С. 167-181].

Osokina D.N., Tsvetkova N.Y., 1979. Modeling method of local stress fields in the vicinity of tectonic fractures and in earthquake foci. In: A.S. Grigoriev, D.N. Osokina (Eds.), Stress and strain fields of the lithosphere. Nauka, Moscow p. 139-162 (in Russian) [Осокина Д.Н., Цветкова Н.Ю. Метод моделирования локальных полей напряжений в окрестностях тектонических разрывов и в очагах землетрясений // Поля напряжений и деформаций в литосфере / Ред. А.С. Григорьев, Д.Н. Осокина. М.: Наука, 1979. С. 139-162].

Park R.G., 1997. Foundations of Structural Geology. Chapman \& Hall, London, 202 p.

Pedersen S.I., Randen T., Sonneland L., Steen O., 2002. Automatic fault extraction using artificial ants. In: $72^{\text {nd }}$ SEG Annual Meeting, Salt Lake City, Utah, USA (October 6-11, 2002). Expanded Abstracts. Salt Lake City, p. 512-515.

Petit C., Déverchère J., Houdry F., Sankov V.A., Melnikova V.I., Delvaux D., 1996. Present-day stress field changes along the Baikal rift and tectonic implications. Tectonics 15 (6), 1171-1191. https://doi.org/10.1029/96TC00624. 
Pospeev A.V., Buddo I.V., Agafonov Yu.A., Kozhevnikov N.O., 2010. Identification of reservoirs in the section of the sedimentary cover of the southern Siberian platform from sounding data by formation of an electromagnetic field in the near zone. Geofizika (Geophysics) (6), 47-52 (in Russian) [Поспеев А.В., Буддо И.В., Агафонов Ю.А., Кожевников Н.О. Выделение пластов-коллекторов в разрезе осадочного чехла юга Сибирской платформы по данным зондирований становлением электромагнитного поля в ближней зоне // Геофизика. 2010. № 6. C. 47-52].

Ryazanov G.V., 1973. Morphology and Genesis of Folds in the Nepa zone. Nauka, Novosibirsk, 88 p. (in Russian) [Рязанов Г.В. Морфология и генезис складок Непской зоны. Новосибирск: Наука. СО, 1973. 88 с.].

Sadovsky M.A., Bolkhovitinov L.G., Pisarenko V.F., 1987. Deformation of Geophysical Medium and Seismic Process. Nauka, Moscow, 100 p. (in Russian) [Садовский М.А., Болховитинов Л.Г., Писаренко В.Ф. Деформирование геофизической среды и сейсмический процесс. М.: Наука, 1987. 100 с.].

Sankov V.A., Dobrynina A.A., 2018. Active faulting in the Earth's Crust of the Baikal rift system based on the earthquake focal mechanisms. In: S. D'Amico (Ed.), Moment tensor solutions. Springer, Cham, p. 599-618. https://doi.org/ 10.1007/978-3-319-77359-9_27.

San'kov V.A., Miroshnichenko A.I., Levi K.G., Lukhnev A., Melnikov A.I., Delvaux D., 1997. Cenozoic stress field evolution in the Baikal rift zone. Bulletin du Centre de Recherches Elf Exploration Production 21 (2), 435-455.

Sankov V.A., Parfeevets A.V., Miroshnichenko A.I., Byzov L.M., Lebedeva M.A., 2008. Coupling of late cenozoic faulting of the Siberian platform margin and Baikal rifting. Doklady Earth Sciences 419 (2), 428-431 https://doi.org/ 10.1134/S1028334X08030161.

Sankov V.A., Parfeevets A.V., Miroshnichenko A.I., Byzov L.M., Lebedeva M.A., Sankov A.V., Dobrynina A.A., Kovalenko S.N., 2017. Late Cenozoic faulting and the stress state in the south-eastern segment of the Siberian platform. Geodynamics \& Tectonophysics 8 (1), 81-105 (in Russian) [Саньков В.А., Парфеевец А.В., Мирошниченко А.И., Бызов Л.М., Лебедева М.А., Саньков А.В., Добрынина А.А., Коваленко С.Н. Позднекайнозойское разломообразование и напряженное состояние юго-восточной части Сибирской платформы // Геодинамика и тектонофизика. 2017. T. 8. № 1. C. 81-105]. https://doi.org/10.5800/GT-2017-8-1-0233.

Seminskii K.Zh., 2008. Hierarchy in the zone-block lithospheric structure of Central and Eastern Asia. Russian Geology and Geophysics 49 (10), 771-779. https://doi.org/10.1016/j.rgg.2007.11.017.

Seminsky K.Zh., 1990. General regularities of the dynamics of structure formation in large strike-slip zones. Geologiya $i$ Geofizika (Soviet Geology and Geophysics) 31 (4), 14-23 (in Russian) [Семинский К.Ж. Общие закономерности динамики структурообразования в крупных сдвиговых зонах // Геология и геофизика. 1990. Т. 31 . № 4. C. 14-23].

Seminsky K.Zh., 2003. The Internal Structure of Continental Fault Zones. Tectonophysical Aspect. Geo Branch, Publishing House of SB RAS, Novosibirsk, 243 p. (in Russian) [Семинский К.Ж. Внутренняя структура континентальных разломных зон. Тектонофизический аспект. Новосибирск: Изд-во СО РАН, филиал «Гео», 2003. 243 c.].

Seminsky K.Zh., 2014. Specialized mapping of crustal fault zones. Part 1: Basic theoretical concepts and principles. Geodynamics \& Tectonophysics 5 (2), 445-467 (in Russian) [Семинский К.Ж. Спецкартирование разломных зон земной коры. Статья 1: Теоретические основы и принципы // Геодинамика и тектонофизика. 2014. Т. 5. № 2. C. 445-467]. https://doi.org/10.5800/GT-2014-5-2-0136.

Seminsky K.Zh., 2015. Specialized mapping of crustal fault zones. Part 2: Main stages and prospects. Geodynamics \& Tectonophysics 6 (1), 1-43 (in Russian) [Семинский К.Ж. Спецкартирование разломных зон земной коры. Статья 2: Основные этапы и перспективы // Геодинамика и тектонофизика. 2015. т. 6. № 1. C. 1-43]. https:// doi.org/10.5800/GT-2015-6-1-0170.

Seminsky K.Zh., Gladkov A.S., Vakhromeev A.G., Cheremnykh A.V., Bobrov A.A., Kogut E.I., 2008. Faults and seismicity of the south of Siberian platform: features of display at different scale levels. Litosfera (Lithosphere) (4), 3-21 (in Russian) [Семинский К.Ж., Гладков А.С., Вахромеев А.Г., Черемных А.В., Бобров А.А., Когут Е.И. Разломы и сейсмичность юга Сибирской платформы: особенности проявления на разных масштабных уровнях // Литосфера. 2008. № 4. С. 3-21].

Seminsky K.Zh., Seminsky Zh.V., 2016. Special Mapping of the Crustal Fault Zones, and Its Possibilities in Studying the Structural Control of Kimberlites in the Alakit-Markha Field, Yakutian Diamond Province. Publishing house of the Irkutsk State Technical University, Irkutsk, 204 p. (in Russian] [Семинский К.Ж., Семинский Ж.В. Спецкартирование разломных зон земной коры и его возможности в исследовании структурного контроля кимберлитов в Алакит-Мархинском поле Якутской алмазоносной провинции. Иркутск: Изд-во ИРНИТУ, 2016. 204 с.].

Seredkina A.I., Melnikova V.I., Gileva N.A., Radziminovich Y.B., 2015. The Mw 4.3 January 17, 2014, earthquake: very rare seismic event on the Siberian platform. Journal of Seismology 19 (3), 685-694. https://doi.org/10.1007/ s10950-015-9487-y.

Sherman S.I., Bornyakov S.A., Buddo V.Yu., 1983. Areas of Dynamic Influence of Faults (Modeling Results). Nauka, Novosibirsk, 110 p. (in Russian) [Шерман С.И., Борняков С.А., Буддо В.Ю. Области динамического влияния разломов (результаты моделирования). Новосибирск: Наука, 1983. 110 с.].

Sherman S.I., Dneprovsky Yu.I., 1989. Fields of Crustal Stresses and Geological and Geophysical Methods of Their Studies. Nauka, Novosibirsk, 158 p. (in Russian) [Шерман С.И., Днепровский Ю.И. Поля напряжений земной коры и геолого-структурные методы их изучения. Новосибирск: Наука, 1989. 158 с.]. 
Sherman S.I., Seminsky K.Zh., Cheremnykh A.V., 1999. Destructive zones and fault-block structures of Central Asia. Tikhookeanskaya Geologiya (Russian Journal of Pacific Geology) 18 (2), 41-53 (in Russian) [Шерман С.И., Семинский К.Ж., Черемных А.В. Деструктивные зоны и разломно-блоковые структуры Центральной Азии // Тихоокеанская геология. 1999. Т. 18. № 2. С. 41-53].

Sizykh V.I., 2001. Sharyazh-Thrust Tectonics of the Margins of Ancient Platforms. SB RAS Publishing House, Novosibirsk, 154 p. (in Russian] [Сизых В.И. Шарьяжно-надвиговая тектоника окраин древних платформ. Новосибирск: Изд-во СО РАН, 2001. 154 с.].

Skvortsov A.A., Kuleshov V.E., 2014. Identification of the systems of natural fracturing from 3 D seismic modeling of the carbonate reservoir (case of the Shchelyaur deposit). Neftegazovoe Delo (Oil and Gas Business) (6), 242-259 (in Russian) [Скворцов A.A., Кулешов B.E. Выделение систем естественной трещиноватости по данным 3D сейсмического моделирования карбонатного коллектора (на примере Щельяюрского месторождения) // Нефтегазовое дело. 2014. № 6. С. 242-259].

Smirnov A.S., Gorlov I.V., Yaitsky N.N., Gorsky O.M., Ignatiev S.F., Pospeev A.V., Vakhromeev A.G., Agafonov Yu.A., Buddo I.V., 2016. Integration of geological and geophysical data - a way to create a reliable model of the Kovykta gas condensate field. Geologiya Nefti i Gaza (Oil and Gas Geology) (2), 56-66 (in Russian) [Смирнов A.C., Горлов И.В., Яицкий Н.Н., Горский О.М., Игнатьев С.Ф., Поспеев А.В., Вахромеев А.Г., Агафонов Ю.А., Буддо И.В. Интеграция геолого-геофизических данных - путь к созданию достоверной модели Ковыктинского газоконденсатного месторождения // Геология нефти и газа. 2016. № 2. С. 56-66].

Sylvester A.G., 1988. Strike-slip faults. Geological Society of America Bulletin 100 (11), 1666-1703. https://doi.org/ 10.1130/0016-7606(1988)100<1666:SSF>2.3.CO;2.

Tchalenko J.S., 1970. Similarities between shear zones of different magnitudes. Geological Society of America Bulletin 81 (6), 1625-1640. https://doi.org/10.1130/0016-7606(1970)81[1625:SBSZOD]2.0.C0;2.

Tsobin V.A., Adamov E.A., 1978. Geological Map of the USSR. Scale 1:200000. Angara-Lena Series. Sheet N-48-XI. Explanatory Note. Moscow, 65 p. (in Russian) [Цобин B.A., Адамов Е.А. Геологическая карта СССР. Масштаб 1:200000. Серия Ангаро-Ленская, лист N-48-XI. Объяснительная записка. М., 1978. 65 с.].

Ufimtsev G.F., Shchetnikov A.A., Myaktova V.V., Filinov I.A., 2005. Geomorphology and morphotectonics of the LenaAngara plateau. Geomorfologiya (Geomorphology) (2), 97-106 (in Russian) [Уфимцев Г.Ф., Щетников А.А., Мяктова В.В., Филинов И.А. Геоморфология и морфотектоника Лено-Ангарского плато // Геоморфология. 2005. № 2. C. 97-106].

Vakhromeev A.G., Khokhlov G.A., 1988. Prospects for the prediction of rapa zones in the Verkholensky (Zhigalovsky) gas-bearing area of the Irkutsk region. In: Features of the technology for drilling and completion of wells in East Siberia and Yakutia. Vostochno-Sibirskaya Pravda Publishing House, Irkutsk, p. 140-142 (in Russian) [Baxромеев А.Г., Хохлов Г.А. Перспективы прогноза зон рапопроявлений в Верхоленском (Жигаловском) газоносном районе Иркутской области // Особенности технологии проводки и закачивания скважин в Восточной Сибири и Якутии. Иркутск: Изд-во «Восточно-Сибирская правда», 1988. С. 140-142].

Vakhromeev A.G., Myshevsky N.V., Khokhlov G.A., 2006. Anomalously high formation pressure as a factor complicating the development of hydrocarbon deposits in East Siberia. In: Modern geodynamics and hazardous natural processes in Central Asia: Fundamental and Applied Aspects. Issue 5. IEC SB RAS, Irkutsk, p. 98-119 (in Russian) [Вахромеев А.Г., Мышевский Н.В., Хохлов Г.А. Аномально высокие пластовые давления как фактор, осложняющий освоение углеводородных месторождений Восточной Сибири // Современная геодинамика и опасные природные процессы в Центральной Азии: фундаментальный и прикладной аспекты. Вып. 5. Иркутск: ИЗК СО РАН, 2006. С. 98-119].

Vakhromeev A.G., Sverkunov S.A., Ilyin A.I., Pospeev A.V., Gorlov I.V., 2016. Mining and geological conditions of drilling brine productive zones with abnormally high reservoir pressure in natural Cambrian reservoirs of the Kovykta gas condensate field. Proceedings of the Siberian Department of the Section of Earth Sciences of the Russian Academy of Natural Sciences. Geology, Exploration and Development of Mineral Deposits (2), 74-87 (in Russian) [Вахромеeв А.Г., Сверкунов С.А., Ильин А.И., Поспеев А.В., Горлов И.В. Горно-геологические условия бурения рапопроявляющих зон с аномально высоким пластовым давлением в природных резервуарах кембрия на Ковыктинском газоконденсатном месторождении // Известия Сибирского отделения Секции наук о Земле Российской академии естественных наук. Геология, разведка и разработка месторождений полезных ископаемых. 2016. № 2. C. 74-87].

Wilcox R.E., Harding T.P., Seely D.R., 1973. Basic wrench tectonics. AAPG Bulletin 57 (1), 74-96.

Wiprut D., Zoback M.D., 2000. Fault reactivation and fluid flow along a previously dormant normal fault in the northern North Sea. Geology 28 (7), 595-598. https://doi.org/10.1130/0091-7613(2000)28<595:FRAFFA>2.0.CO;2.

Zamaraev S.M., Adamenko O.M., Ryazanov G.V., Kulchitsky A.A., Adamenko R.S., Vikentieva N.M., 1976. Structure and History of the Development of the Predbaikalsky foredeep. Nauka, Moscow, 134 p. (in Russian) [Замараев C.M., Адаменко О.М., Рязанов Г.В., Кульчицкий А.А., Адаменко Р.С., Викентьева Н.М. Структура и история развития Предбайкальского предгорного прогиба. М.: Наука, 1976. 134 с.].

Zeng L., Wang H., Gong L., Liu B., 2010. Impacts of the tectonic stress field on natural gas migration and accumulation: A case study of the Kuqa Depression in the Tarim Basin, China. Marine and Petroleum Geology 27 (7), 1616-1627. https://doi.org/10.1016/j.marpetgeo.2010.04.010.

Zolotarev A.G., 1967. New data on neotectonics and its expression in morphostructures of the southeastern part of the Central Siberian plateau and the Baikal mountain region. In: Tectonic movements and the most recent structures 
of the Earth's Crust. Proceedings of the Meeting on Neotectonics Problems. Nedra, Moscow, p. 399-393 (in Russian) [Золотарев А.Г. Новые данные о неотектонике и ее выражении в морфоструктурах юго-восточной части Средне-Сибирского плоскогорья и Байкальской горной области // Тектонические движения и новейшие структуры земной коры: Материалы совещания по проблемам неотектоники. М.: Недра, 1967. C. 399-393].

Zolotarev A.G., Khrenov P.M. (Eds.), 1979. Map of the Most Recent Tectonics of the Southern East Siberia. Scale 1:1500000. VostSibNIIGGiMS, Irkutsk (in Russian) [Карта новейшей тектоники юга Восточной Сибири. Масштаб 1:1500000 / Ред. А.Г. Золотарев, П.М. Хренов. Иркутск: ВостСибНИИГГиМС, 1979].

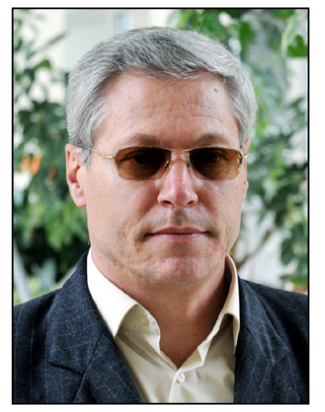

Константин Жанович Семинский, докт. геол.-мин. наук, заместитель директора

Институт земной коры СО РАН

664033, Иркутск, ул. Лермонтова, 128, Россия

e-mail: seminsky@crust.irk.ru

ORCID ID https://orcid.org/0000-0001-7607-0417

Konstantin Zh. Seminsky, Doctor of Geology and Mineralogy, Deputy Director Institute of the Earth's Crust, Siberian Branch of RAS

128 Lermontov street, Irkutsk 664033, Russia

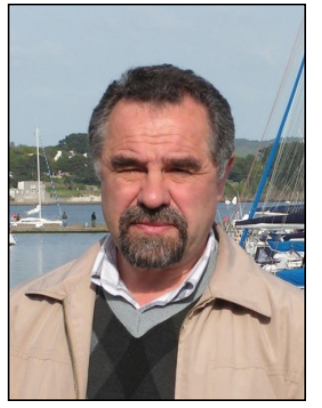

Владимир Анатольевич Саньков, канд. геол.-мин. наук, зав. лабораторией

Институт земной коры СО РАН

664033, Иркутск, ул. Лермонтова, 128, Россия

Иркутский государственный университет, геологический факультет

664003, Иркутск, ул. Ленина, 3, Россия

e-mail: sankov@crust.irk.ru

ORCID ID https://orcid.org/0000-0002-1066-2601

Vladimir A. Sankov, Candidate of Geology and Mineralogy, Head of Laboratory

Institute of the Earth's Crust, Siberian Branch of RAS

128 Lermontov street, Irkutsk 664033, Russia

Irkutsk State University, Geological Faculty

3 Lenin street, Irkutsk 664003, Russia

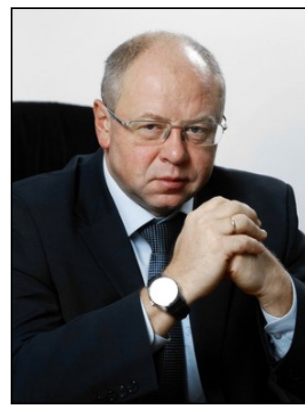

Валерий Владимирович Огибенин, канд. геол.-мин. наук, начальник инженерно-технического центра 000 «Газпром геологоразведка» 625000, Тюмень, ул. Герцена, 70, Россия

e-mail: v.ogibenin@ggr.gazprom.ru

Valery V. Ogibenin, Candidate of Geology and Mineralogy, Head of the Engineering and Technical Center LLC Gazprom Geologorazvedka

70 Gertsen Street, Tyumen 625000, Russia 


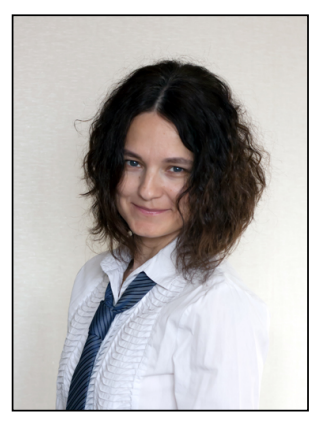

Юлия Петровна Бурзунова, канд. геол.-мин. наук, ведущий инженер Институт земной коры СО РАН 664033, Иркутск, ул. Лермонтова, 128, Россия

e-mail: burzunova@crust.irk.ru ORCID ID https://orcid.org/0000-0002-9955-0314

Yulia P. Burzunova, Candidate of Geology and Mineralogy, Lead Engineer Institute of the Earth's Crust, Siberian Branch of RAS 128 Lermontov street, Irkutsk 664033, Russia

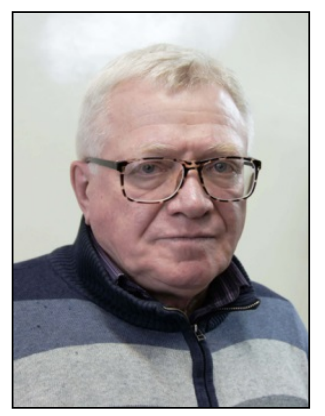

Андрей Иванович Мирошниченко, канд. геол.-мин. наук, с.н.с. Институт земной коры СО РАН 664033, Иркутск, ул. Лермонтова, 128, Россия

e-mail: mai@crust.irk.ru ORCID ID https://orcid.org/0000-0003-2749-8825

Andrei I. Miroshnichenko, Candidate of Geology and Mineralogy, Senior Researcher Institute of the Earth's Crust, Siberian Branch of RAS 128 Lermontov street, Irkutsk 664033, Russia

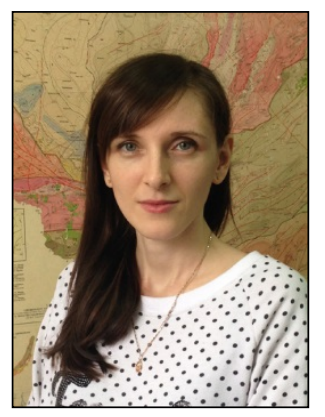

Екатерина Алексеевна Горбунова, канд. геол.-мин. наук, м.н.с. Институт земной коры СО РАН 664033, Иркутск, ул. Лермонтова, 128, Россия

e-mail: smallwizard@mail.ru

Ekaterina A. Gorbunova, Candidate of Geology and Mineralogy, Junior Researcher Institute of the Earth's Crust, Siberian Branch of RAS 128 Lermontov street, Irkutsk 664033, Russia

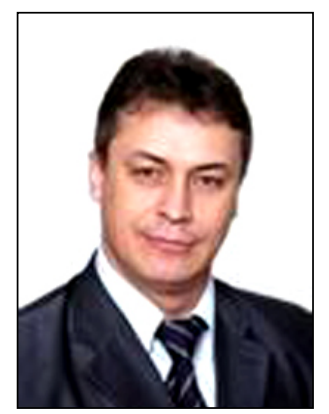

Иван Владимирович Горлов, заместитель начальника инженерно-технического центра 000 «Газпром геологоразведка» 625000, Тюмень, ул. Герцена, 70, Россия

e-mail: i.gorlov@ggr.gazprom.ru

Ivan V. Gorlov, Deputy Head of the Engineering and Technical Center

LLC Gazprom Geologorazvedka

70 Gertsen Street, Tyumen 625000, Russia

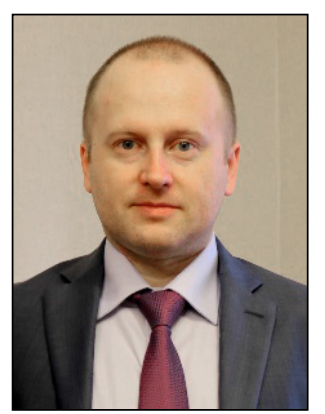

Александр Сергеевич Смирнов, канд. геол.-мин. наук, начальник отдела инженерно-технического центра

000 «Газпром геологоразведка» 625000, Тюмень, ул. Герцена, 70, Россия

Тюменский индустриальный университет 625000, Тюмень, ул. Володарского, 38, Россия

e-mail: a.smirnov@ggr.gazprom.ru,smirnovas@tyuiu.ru

Aleksander S. Smirnov, Candidate of Geology and Mineralogy, Head of Section of the Engineering and Technical Center

LLC Gazprom Geologorazvedka

70 Gertsen Street, Tyumen 625000, Russia

Tyumen Industrial University

38 Volodarsky street, Tyumen 625000, Russia 


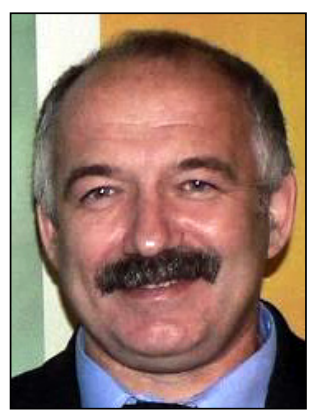

Андрей Гелиевич Вахромеев, докт. геол.-мин. наук, зав. лабораторией Институт земной коры СО РАН

664033, Иркутск, ул. Лермонтова, 128, Россия

e-mail:VakhromeevAG@ifrnb.ru

Andrei G. Vakhromeev, Doctor of Geology and Mineralogy, Head of Laboratory Institute of the Earth's Crust, Siberian Branch of RAS

128 Lermontov street, Irkutsk 664033, Russia

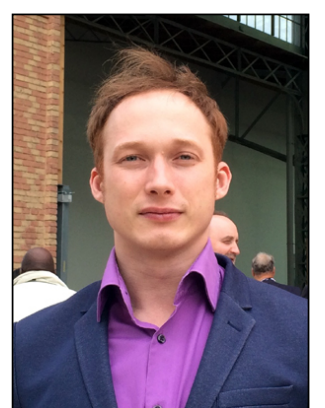

Игорь Владимирович Буддо, канд. геол.-мин. наук, н.с.

Институт земной коры СО РАН

664033, Иркутск, ул. Лермонтова, 128, Россия

e-mail: igor.buddo@yandex.ru

Igor V. Buddo, Candidate of Geology and Mineralogy, Researcher Institute of the Earth's Crust, Siberian Branch of RAS

128 Lermontov street, Irkutsk 664033, Russia 